\title{
Assessment of women's benefits and constraints in participating in agroforestry exemplar landscapes
}

Nguyen Mai Phuong, Hanna North, Duong Minh Tuan, Nguyen Manh Cuong 



\section{Assessment of women's benefits and constraints in participating in agroforestry exemplar landscapes}

Nguyen Mai Phuong, Hanna North, Duong Minh Tuan, Nguyen Manh Cuong 

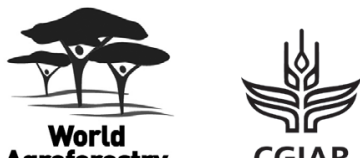

RESEARCH

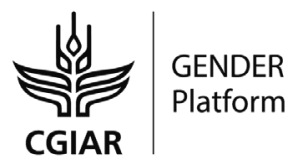

\section{Citation}

Nguyen MP, North H, Duong MT, Nguyen MC. 2021. Assessment of women's benefits and constraints in participating in agroforestry exemplar landscapes. Working paper 315. Nairobi, Kenya: World Agroforestry (ICRAF). https://dx.doi.org/10.5716/ WP21015.PDF.

\section{Published by World Agroforestry (ICRAF)}

United Nations Avenue

[PO Box 30677, GPO 00100]

Nairobi, Kenya

Tel: +254(0)20 7224000, via USA +1 6508336645

Fax: +254(0)20 7224001, via USA +1 6508336646

Email: worldagroforestry@cgiar.org; icraf-vietnam@cgiar.org

Website: www.worldagroforestry.org

(C) World Agroforestry (ICRAF) 2021

The views expressed in this publication are those of the author(s) and not necessarily those of the World Agroforestry. Articles appearing in this publication may be quoted or reproduced without charge, provided the source is acknowledged. All images remain the sole property of their source and may not be used for any purpose without written permission of the source. 


\section{About the authors}

Nguyen Mai Phuong is a researcher at World Agroforestry (ICRAF) Viet Nam. She holds an MSc from Viet Nam National University on global information systems and remote sensing and a PhD in Agroforestry from Bangor University, UK. She works on agroforestry systems, project assessments, ethnic minorities and gender issues.

Hanna North is a gender project consultant with ICRAF Viet Nam. She conducted the comparative analysis and was involved in writing and organizing this working paper.

Duong Minh Tuan is a project officer with ICRAF Viet Nam. He was involved in the dataset cleaning and analysis for this working paper.

Nguyen Manh Cuong is a short-term consultant with ICRAF Viet Nam, involved in the dataset cleaning and analysis for this working paper. 


\section{Contents}

$\begin{array}{lr}\text { 1. Introduction } & 10\end{array}$

1.1 Background 10

1.2 Project intervention $\quad 13$

2. Methodology and study site $\quad 15$

2.1 Study site $\quad 15$

2.1.1 Overall assessment $\quad 15$

$\begin{array}{ll}\text { 2.1.2 The two case studies } & 15\end{array}$

2.2 Participatory methods and gender-responsive approach 16

3. Results $\quad 17$

3.1 Assessment of benefits for women from participating in AFLi exemplar landscapes $\quad 17$

$\begin{array}{ll}\text { 3.1.1 Women's perception of agroforestry benefits } & 17\end{array}$

3.1.2 Improved knowledge and skills through training and project material $\quad 18$

3.1.3 Adoption of agroforestry options and soil and water conservation techniques $\quad 19$

$\begin{array}{ll}\text { 3.1.4 Social benefits } & 19\end{array}$

3.2 Case studies from Thai and Hmong ethnic groups: the gender divide in context 20

$\begin{array}{ll}3.2 .1 \text { Gender norms and family dynamics } & 20\end{array}$

3.2.2 Labour division $\quad 23$

$\begin{array}{ll}3.2 .3 \text { Time wheels } & 25\end{array}$

3.2.4 Access to resources $\quad 28$

3.2.5 Women's interests $\quad 30$

4. Gendered constraints to project interventions: discussion $\quad 34$

4.1 Women's involvement in the project's activities $\quad 34$

4.2 Women's influence on the success of the project 35

5. Key recommendations

6. Conclusion $\quad 40$

Appendix $\quad 41$

References $\quad 65$

Recent titles in the working paper series $\quad 68$ 


\section{Figures}

Figure 1. Fifty hectare exemplar landscape with trees and forage grass planted along contour

lines on sloping land in Hat Lot District, Son La Province. Photo: World Agroforestry in Viet Nam

Figure 2. Map of the study sites. Source: World Agroforestry

Figure 3. Project's impact on women's perception of agroforestry benefits

Figure 4. Impact of training activities on women

Figure 5. Impact of extension material on women

Figure 5. Impact of activities on women's social skills

Figure 7. Men and women's perceived degree of power and freedom in the Hmong ethnic-minority community of Toa Tinh Commune

Figure 5. Labour division in Thai ethnic minority in Hat Lot commune and

Hmong ethnic minority in Toa Tinh commune

Figure 9. Gendered 24-hour time wheels

Figure 10. Gendered allocation of resource ownership and use

Figure 11. Agroforestry system with fruit trees and pumpkin. Photo: World Agroforestry

Figure 12. Hmong and Thai women's interests

Figure 13. Young Hmong woman: 'Archery is my favourite sport. I hope I can go for

competitions at district and provincial levels.' Photo: World Agroforestry

Figure 14. Number of men and women transferring project techniques to others 


\section{Acknowledgements}

This collaborative research project was funded by the Australian Centre for International Agricultural Research, conducted as part of activities for the project, Developing and Promoting Marketbased Agroforestry and Forest Rehabilitation Options for Northwest Vietnam (FST/2016/152, AGR/2017/008), and undertaken as part of, and funded by the CGIAR Research Program on Forest Trees and Agroforestry (FTA) and the CGIAR GENDER Platform.

We thank our colleagues at World Agroforestry (ICRAF) Viet Nam and Headquarters, International Potato Center, Institute for Social Development Studies and CARE International in Viet Nam, research assistants Vang A Pao, Nguyen Thanh Van, Pham Thi Huyen and Le Manh Tri, whose expertise greatly assisted the research.

We would also like to thank the officials and staff of the agricultural service centres of Dien Bien and Son La provinces, Toa Tinh and Hat Lot communes' people's committees, and Hua Sa A and Na Bai villages' leaders, for their active participation and support for our field activities.

We thank the men and women farmers who openly shared information, their perspectives and insights during the field work, discussions and other activities during the study period. 


\begin{abstract}
Participating in the exemplar landscapes of the Developing and Promoting Market-Based Agroforestry and Forest Rehabilitation Options for Northwest Vietnam project has had positive impacts on ethnic women, such as increasing their networks and decision-making and publicspeaking skills. However, the rate of female farmers accessing and using project extension material or participating in project nurseries and applying agroforestry techniques was limited. This requires understanding of the real needs and interests grounded in the socio-cultural contexts of the ethnic groups living in the Northern Mountain Region in Viet Nam, who have unique social and cultural norms and values. The case studies show that agricultural activities are highly gendered: men and women play specific roles and have different, particular constraints and interests. Women are highly constrained by gender norms, access to resources, decision-making power and a prevailing positive-feedback loop of time poverty, especially in the Hmong community. A holistic, timesaving approach to addressing women's daily activities could reduce the effects of time poverty and increase project participation. As women were highly willing to share project information, the project's impacts would be more successful with increased participation by women through utilizing informal channels of communication and knowledge dissemination. Extension material designed for ethnic women should have less text and more visuals. Access to information is a critical constraint that perpetuates the norm that men are decision-makers, thereby, enhancing their perceived ownership, whereas women have limited access to information and so leave final decisions to men, especially in Hmong families. Older Hmong women have a Vietnamese (Kinh) language barrier, which further prevents them from accessing the project's material. Further research into an adaptive framework that can be applied in a variety of contexts is recommended. This framework should prioritize time-saving activities for women and include material highlighting key considerations to maintain accountability among the project's support staff.
\end{abstract}

\title{
Keywords
}

Gender, Hmong, Thai, norms, information, agriculture, participation, time poverty, decisionmaking, empowerment, challenges, opportunities, Dien Bien, Son La, Viet Nam 


\section{Introduction}

\subsection{Background}

Women play an integral role in agriculture globally, contributing labour and expertise that are invested in the livelihoods of themselves and their families. Agricultural extension services offer support towards enhancing agricultural productivity within the context of local communities yet women are repeatedly left behind in these efforts due to socio-cultural norms, limited access to information and gendered resource allocation (FAO 2019). Agricultural innovation for smallholding farmers is highly gendered within patriarchal family structures (Kawarazuka \& Prain 2019), where women are often positioned in relation to their husbands and perceived as 'farmer's wives' instead of professional farmers themselves (Brandth 2002, Meinzen-Dick et al 2010). This perception has led to women's exclusion from agricultural training because they may be considered as 'unnecessary' (Peterman et al 2014), further limiting their access to tools and information.

One of the most pervasive barriers that women face in empowerment in agriculture is their decisionmaking roles at community and household level (Sraboni et al 2014). Rose (1993) describes a 'paradoxical space' where an individual retains multiple identities, each with its own implications to how a person is placed within their social sphere. Kawarazuka \& Prain (2018) employ this concept with the Thai ethnic minority community in Viet Nam, delineating a complex hierarchy of agency within identities such as mother, youth, in-law, farmer or literate, differentiating each individual woman's agency towards decision-making. Other contexts, such as Bangladesh (Sraboni et al 2014), Ghana (Diawuo et al 2019) and India (Raghunathan et al 2019) see similar patterns of male-preferential decision-making and complex familial roles for women, which are often exacerbated by cultural perceptions of women's capability. Kiptot \& Franzel (2012) found that, in Africa, men were more often managers of agroforestry systems, despite women conducting the majority of on-farm labour, and that men often held claims over women's labour where the inverse was not true. It is often reported that men consult their wives regarding decisions that affect shared domains (Diawuo et al 2019), however, stereotypes regarding women's education levels, perceived laziness or incapacity in agriculture persist, reducing men's inclination to seek counsel from their wives (Mudege et al 2017). While men generally hold decision-making power over shared domains, women do hold autonomous domains, however, they are often limited to by-products of men's labour, for example, Chikoko (2002) describes women's influence on tree products as increasing outwards from stem to twig as men are the proprietors of the timber trade and women are responsible for collecting fruit and non-timber forest products. Women also generally hold domain over home gardens (Mamunur-Rashid et al 2017; Voegele et al 2009) but persistent gender norms dictate that women's domains in general are less efficient in terms of technological involvement and returns on labour (Chikoko 2002, Kawarazuka \& Prain 2018).

The implications of the imbalance of decision-making power in families on small-holders' farms are exacerbated by women's lack of tenure, their time poverty and limited access to resources. Women's property is often poor in condition and quality and therefore low in collateral value, making them less-than-ideal candidates for loans or financial support (Catacutan \& Naz 2015, Mamun-ur-Rashid et al 2017). Kawarazuka \& Prain (2018) note that the notion of innovation is gendered where men in the Northern Mountainous Region of Viet Nam perceive innovation as actions that increase capital and yield whereas women perceive innovation as time-saving changes to everyday practices. These findings support common assumptions that women are heavily constricted by their daily activities and that strong consideration for women's time poverty and domestic responsibilities is needed to increase participation in agricultural innovation and training projects (Diawuo et al 2019, Mbo'o-Tchouawou \& Colverson 2014, Raghunathan et al 2019). Though the majority of women's 
livelihoods' options are related to agriculture, their low participation in training or community meetings due to domestic responsibilities and child-care mean that their feedback and needs are not heard or prioritized, even when they are technically invited to participate (Green Climate Fund 2020).

The Women's Empowerment in Agriculture Index proposes five domains of empowerment indicators (production, resources, income, leadership and time) which manifest differently in diverse contexts (Alkire et al 2013). Women's empowerment in agriculture has been found to benefit communities, for example, by diversifying nutritional input to children (Sraboni et al 2014), and benefit women by increasing their confidence, self-reliance and skills (Kawarazuka \& Prain 2019). Increasing women's income is additionally positively correlated with children's highest year of schooling (Qian 2008, Luke \& Munshi 2011), indicating that women's empowerment in agriculture ought to be a priority in rural communities to disrupt the cycle of poverty. However, a disproportionate responsibility falls on the shoulders of women in the face of the climate crisis, as women play an intrinsic role in the management of food systems and provisioning ecosystem services (Nellemann et al 2011). Women are estimated to provide $50 \%$ or more of the labour force in agriculture in Africa and Asia and their livelihoods are highly sensitive to, and dependent on, agriculture (Nellemann et al 2011). In Viet Nam, poor and ethnic-minority women have low capacity to access adaptation techniques, despite being most vulnerable to water and food insecurity (FAO 2019). The Green Climate Fund (2020) calls on policymakers and extension services to increase adaptive agricultural training and promote equal access to climate information based on gender, age and ethnic minorities; communities that are most vulnerable to the negative effects of the climate crisis in Viet Nam. Doss et al (2018) address the widespread belief of women as 'intrinsically better stewards of the environment' and infer that this is a harmful misperception, which places the responsibility of conservation on women without an understanding of community constraints, leaving women behind in terms of resource allocation and supporting services. Men and women who normally receive information from extension services, globally, are currently experiencing unfounded barriers in their access to information due to the COVID-19 pandemic wherein women are disproportionately affected (Alvi et al 2021). Phone panel surveys conducted in Nepal and India indicate that while several factors can limit women's participation with extension services, such as resource allocation, time constraints and geographical location, nearly $50 \%$ of farmers at the study site reported losses in productivity due to inaccessibility of information (Alvi et al 2021). For agricultural extension services to supply adaptive and inclusive information, community-level contexts, constraints and effective information dissemination must be incorporated into the extension framework.

Solutions to women's exclusion from agricultural extension training commonly emphasise increasing women's collaborative and support groups. Cultural bias inflicts restrictive stereotypes about women's capabilities that are structural and extend beyond husbands to extension officers and village leaders. Mudege et al (2017) found that extension officers reinforce the view of men as household heads and keepers of information by using biased training recruitment methods that favour men, under the guise of prioritizing household heads who own plots of ideal size and quality that women disproportionately do not have tenure over. This in turn strengthens the power dynamic wherein men become the 'knowers' of agricultural information and women are perceived as unintelligent and in need of guidance (Mudege et al 2015). Many studies suggest that the recruitment of female extension officers would increase women's participation in extension training (Diawuo et al 2019, Kiptot \& Franzel 2012, Manfre et al 2013, Mudege et al 2015). This is potentially an ambitious undertaking given that female officer recruitment is often low, for example, at only 7\% in the Department of Agricultural Extension in Bangladesh, that country's largest service provider (Malone et al 2013). Women's access to training can similarly be limited by cultural seclusion (Sraboni et al 2013), interception of male village leaders who reinforce gender norms (Mudege et al 2017) or simply by the placement of training schedules at inconvenient times of day when women are preoccupied (Mamun-ur-Rashid et al 2017). Women's groups provide the opportunity for extension staff to target women around their schedules and focus on domains in which they hold autonomous decision-making power or that affect their livelihoods directly; an effort which women's organisations and NGOs efforts have had some success in promoting (Raghunathan et al 2019, Sulaiman \& Reddy 2014). Single-sex groups have been shown to increase women's confidence and enhance their leadership skills (Manfre et al 2013) and targeting pre-existing women's associations has shown to be 
an effective method for dissemination of knowledge to women and by women (Kiptot \& Franzel 2012, Raghunathan et 2019). Raghunathan et al (2019) compared three pathways of improving women's access to agricultural innovation: providing agricultural information; income support; and empowerment through social capital. Each pathway presented unique benefits for participants but did not necessarily increase uptake of new agricultural practices or improved cultivation on its own. The study concluded that income, social, domestic and market constraints impeded adoption of new practices but evidence suggests that women's group membership can affect change in the social sphere.

The results of this study suggest that extending services directly to women needs to address cultural contexts as a potential barrier to implementing technical information received during training.

Agricultural development projects are faced with a unique challenge in Viet Nam due to the presence of 53 recognised ethnic-minority groups, who made up only $14 \%$ of the population but 73\% of the country's poor in 2016 (World Bank 2019), and who differ in cultural norms and nuanced contexts within the country. As a whole, ethnic minorities in Viet Nam are disadvantaged compared with the Kinh majority in terms of levels of education and literacy; access to resources, information and healthcare; life expectancy; and proficiency in the Vietnamese (Kinh) language, among other challenges (Dang 2012, UN Women 2017). Women in ethnic minorities in Viet Nam are further marginalized in all of these areas by cultural drivers that perpetuate systems of disempowerment, such as child marriage, which occurs in nearly $27 \%$ of the ethnic-minority population but just under $1.5 \%$ of the Kinh population (UN Women 2017). Compared with their male counterparts, ethnicminority women have less education, younger working ages, less likelihood of owning agricultural machines, poorer proficiency in Vietnamese, and less likelihood of owning a motorcycle (a distinct obstacle for the 15 ethnic-minority groups who live 20-70 km from their 'local' markets (UN Women 2017)). Women in Viet Nam made up 58\% of the workforce in agriculture in 2015 (FAO, 2015), where more than $81 \%$ of the ethnic minority population were employed in agriculture in 2017; twice as high as for the Kinh population (UN Women 2017). Despite efforts by the Government of Viet Nam to increase gender equality - such as the promulgation of the Land Law in 2001, which decreed that agricultural plots be registered under the names of both husband and wife (Menon et al 2014) - women still struggle with access to land tenure, collateral for loans, infrastructure and financial constraints (Catacutan \& Naz 2015, FAO 2019, Kawarazuka \& Prain 2019). Women are additionally disadvantaged with respect to decision-making power at household level, although this is notably shifting, especially as seasonal migration is leaving more female-headed households in the wake of absent men (Green Climate Fund 2020, Kawarazuka \& Prain 2018). However, female-headed households experience different barriers to male-headed households, such as being more likely to experience labour shortages and difficulties in accessing loans and information. As a result, femaleheaded households are less likely to adopt agroforestry practices, despite expressing more interest in this practice than men in some cases (Catacutan \& Naz 2015). UN Women (2017) determined that fertility rates among ethnic minority groups in 2014/15 were 2.38 children per woman, compared with 2.02 per Kinh woman, and although some groups commonly had up to 5 children per woman, this is a critical contextual factor given the lower familial labour force that most families in Viet Nam have compared with other developing countries with higher fertility rates. Women in ethnic minorities in Viet Nam are highly constrained by their reproductive and domestic duties, much the same as the Kinh minority, though cultural differences between the 53 minority communities inevitably determine how this manifests in relation to personal livelihoods.

Current research into the cultural context of ethnic-minority groups in Viet Nam are often generalized (UN Women 2017) or are specific to singular groups (Catacutan \& Naz 2015, Kawarazuka \& Prain 2010, Lee 2005).

This working paper seeks to generate insights into how cultural nuance affected women's uptake of agricultural innovation promoted by the Developing and Promoting Market-Based Agroforestry and Forest Rehabilitation Options for Northwest Vietnam project - particularly, through 
participating in exemplar landscapes - by comparing the contexts of a Hmong community in Dien Bien Province and a Thai community in Son La Province.

Time poverty and its manifestation in different ethnic minority communities, dictating their opportunities and constraints, is a key theme of this study. The objectives of the study are as follows.

1. Assess the benefits and constraints of women participating in six exemplar landscapes.

2. Observe and compare key benefits and constraints in women's livelihoods and access to agricultural extension services in two case studies in Toa Tinh and Hat Lot communes.

3. Determine the implications of barriers to women's empowerment in agriculture for the success of agricultural interventions.

4. Make recommendations for extension staff which are sensitive to women's unique circumstances and that are adaptable to a wide range of contexts.

\subsection{Project intervention}

The Agroforestry for Smallholder Farmers in Northwest Vietnam (AFLi) project (2011-2016) successfully encouraged farmers to adopt agroforestry systems to combat environmental degradation, diversify agricultural products and obtain higher incomes compared with monocultural systems ${ }^{1}$. Researchers, provincial extension staff, farmers and commune and village leaders joined forces to manage agroforestry exemplar landscapes that demonstrated agroforestry practices to communities, local governments and agencies.

The Developing and Promoting Market-Based Agroforestry and Forest Rehabilitation Options for Northwest Vietnam project (AFLi 2) (2017-2021) is the ongoing response to indicators of local challenges to farmers in adopting agroforestry.

\section{AFLi (2011-2016) objectives}

1. To develop best-practice agroforestry systems for three agro-ecological zones $(<600 \mathrm{~m}$, $600-800 \mathrm{~m}$ and $>800 \mathrm{~m}$ )

2. To improve the availability of high-quality germplasm to enable the expansion of agroforestry systems.

3. To enhance market access and opportunities for adding value to agroforestry products.

4. To improve extension methods and policy dialogues for successful dissemination of agroforestry systems.

\section{AFLi 2 (2017-2021) objectives}

1. Quantify and evaluate generic agroforestry options and tree species to promote investment in agroforestry.

2. Understand the suitability of different agroforestry options for different contexts and develop markets and policy to scale up adoption.

3. Understand the ecological and economic values of degraded forests and co-develop forest rehabilitation methods with local communities to enhance them.

${ }^{1}$ See the final report at https://www.aciar.gov.au/sites/default/files/project-page-docs/final_report_fst.2010.034.pdf 
4. Understand drivers of land-use change and develop cross-sectoral planning approaches for landscapes that integrate forest and agroforestry land uses.

5. Develop local capacity in agroforestry, forest rehabilitation and integrated landscape management.

The first exemplar landscape of the AFLi 2 project was established in Na Ban Village, Hat Lot Commune, Mai Son District, Son La Province. Researchers, provincial extension staff, farmers and commune and village leaders worked together to establish and manage the landscape, the aim of which was to demonstrate wider-scale adoption of agroforestry, attracting support from local governments and other agencies. The establishment and maintenance of the exemplar landscape was cost-shared by the project, the provincial government (seedlings, staff salaries) and the farmers who contributed their land, time and labour.

The landscape is a 50-hectare connected area with 29 farmers involved. Key activities included establishing contoured grass strips as an initial approach to controlling soil erosion, which also provided fodder for livestock and, to some extent, cash income. Fruit-tree species were selected in a participatory manner and planted by farmers above the grass strips. Local arrangements or rules with respect to running the exemplar landscape were agreed upon by farmers together with commune and village leaders, extension workers and project staff. Maize or upland rice were grown together with fruit trees and grass in the first four years.

As well as providing support for planting trees and crops, the project facilitated field visits for participating farmers (known as 'farmer co-operators'), other farmers and extension workers from neighbouring villages, communes and districts to the exemplar landscape. The project also conducted numerous training sessions on different aspects of agroforestry for farmers participating in the landscape. Topics included agroforestry design and management, nursery establishment, seedling production through different techniques such as grafting and marcotting, tree pruning, and management of pests and diseases. The project also built capacity by publishing learning and extension material.

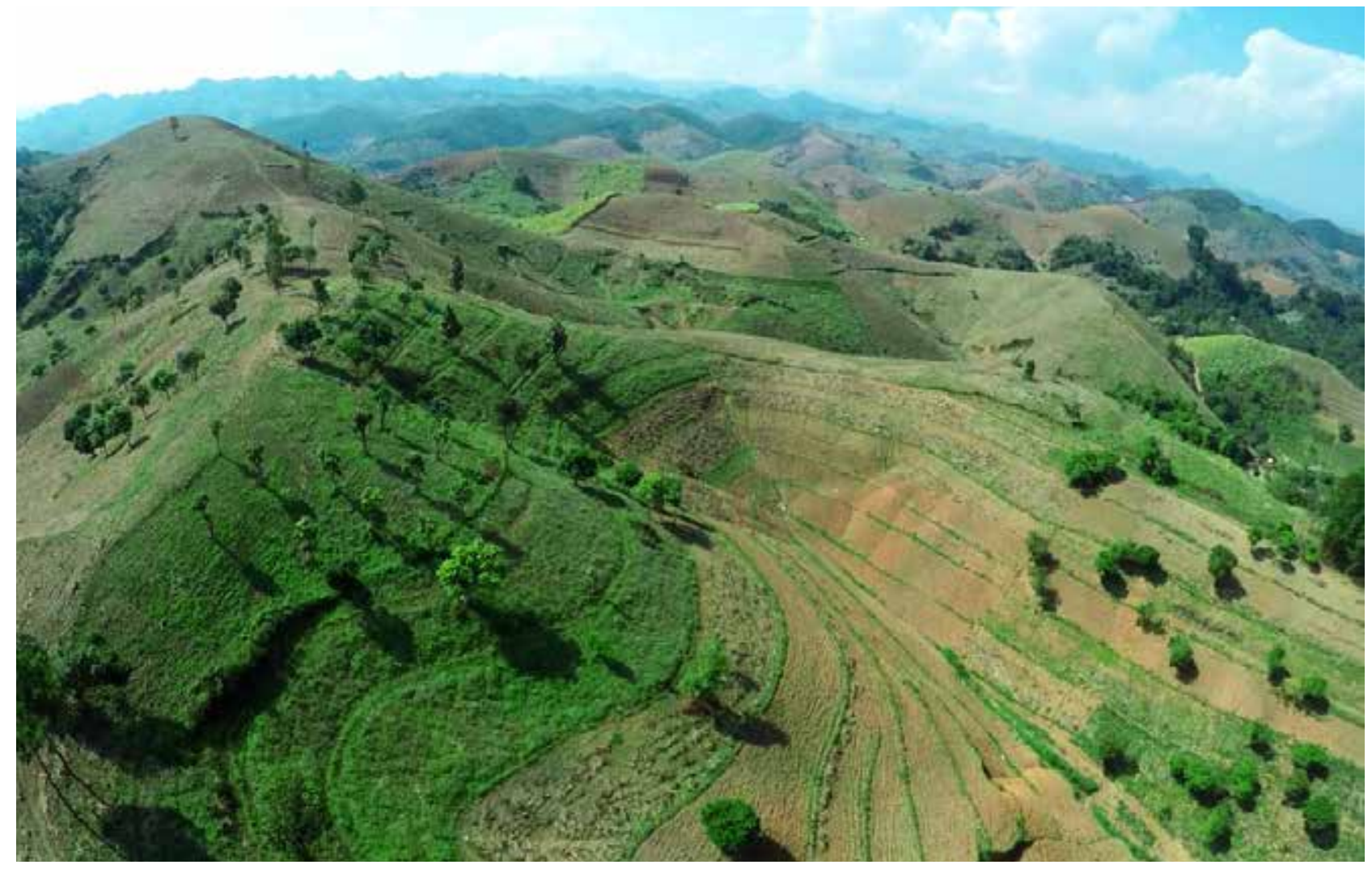

Figure 1. Fifty hectare exemplar landscape with trees and forage grass planted along contour lines on sloping land in Hat Lot District, Son La Province. Photo: World Agroforestry in Viet Nam 
Women have specific gender-based constraints to adopting agroforestry on smallholding farms, which have an impact on the success or otherwise of a project. Ethnic-minority groups are influenced by cultural nuances and unique geographical contexts in Viet Nam, which affect women's access to agricultural extension services on an individual basis. To ensure the success of the ongoing AFLi project and its successors, gendered opportunities and constraints must be better understood within and between communities to ensure the equal participation of men and women and to ensure that women's unique needs are met.

\section{Methodology and study site}

\subsection{Study site}

\subsubsection{Overall assessment}

The overall impact of the AFLi 2 project on women was assessed in six exemplar landscapes in $\mathrm{Na}$ Nhan, Toa Tinh, Hat Lot, Chieng Yen, Xa Ho and Thuong Bang La communes in Dien Bien, Son La and Yen Bai provinces, respectively (Figure 2). The total number of farmers involved in the survey was 182 (95 of whom were women) and 43 'control' farmers (22 of whom were women).

The main ethnic minorities engaged with the exemplar landscapes are Thai, Hmong, Kinh, Muong and Tay. Farmers in the Hat Lot commune had participated in the exemplar landscape since 2015 during the first AFLi project. Farmers in the other landscapes joined from 2017 until the present during the second phase (AFLi 2).

Of all six exemplar landscapes of AFLi 2, only in Hat Lot Commune have farmers received economic revenue from the agroforestry options because the other landscapes are still at early stages. Hat Lot was also the focus of AFLi 2 in supporting ethnic-minority farmers to develop markets for agroforestry products. Therefore, this landscape was selected for the assessment of benefits to women from participating in an exemplar landscape.

\subsubsection{The two case studies}

These case studies were researched in two ethnic-minority communities in Hat Lot and Toa Tinh communes. The Thai and Hmong ethnic groups are two of the six minority groups that have populations over 1 million in Viet Nam (UN Women 2017). The Thai community of Na Ban Village in Hat Lot Commune of Son La Province was established in 1960 and all households have land certificates. The average landholding in Na Ban is 2-3 hectares per household with an additional 200-300 $\mathrm{m}^{2}$ for the home and garden. In Dien Bien Province, Toa Tinh Commune is home to seven villages, Hua Xa B being the most developed. Toa Tinh Commune was established in 1952 and is now home to more than 2000 people, all of whom belong to the Hmong ethnic group.

Thai groups in the Northwest generally live in the middle altitudinal zone (600-800 masl) while Hmong groups tend to live at higher altitudes (above 800 masl). This has major implications for the communities' mobility in terms of distance to markets and access to resources, especially given the seasonal effect of rain on the condition of the dirt roads characteristic of the highland regions of the Northwest. 


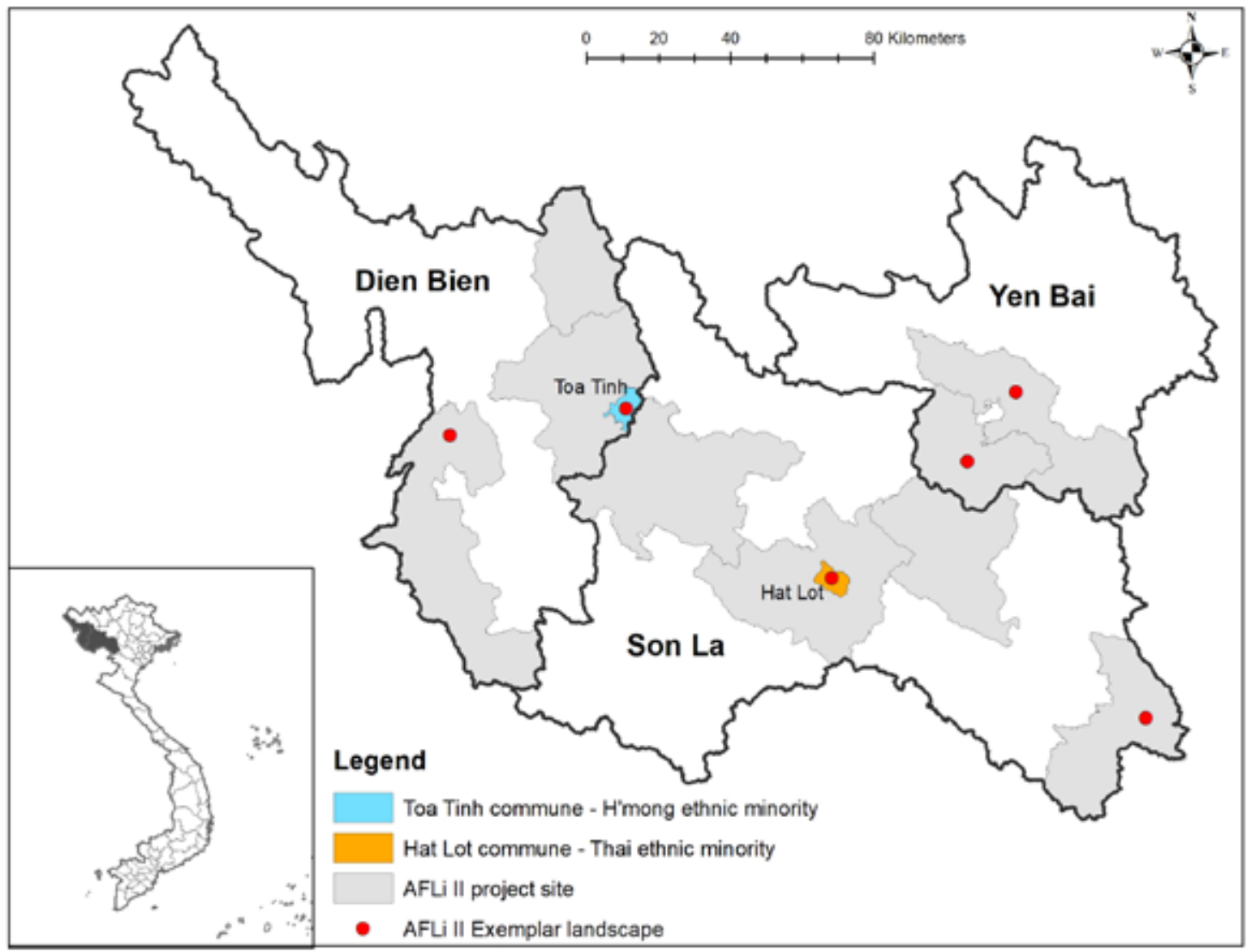

Figure 2. Map of the study sites. Source: World Agroforestry

\subsection{Participatory methods and gender-responsive approach}

The first survey focused on individual social benefits, such as improved awareness, knowledge of, and skills in, agroforestry implementation, farmers' networks, and use and dissemination of project material.

The case studies used qualitative data collected using gender-responsive surveys discussing project impacts and community barriers to uptake. Participants first engaged in a half day of introductory activities to build rapport, employing the Social Analysis and Action approach developed by CARE International (CARE 2017). One and a half days were then spent in focus-group discussions based on GENNOVATE methods (Petesch et al 2018), including the 'ladder of power and freedom' framework, 24-hour time allocation, gendered division of labour and decision-making structures. Participants were divided into four groups by gender (male or female) and age (15-30 and 30-60 years-old) for all activities, excluding the introductory half-day. The final full day of the study included a photo-taking activity where participants were given a set of guiding questions and asked to photograph their responses, later providing their reasoning to researchers. Photos were displayed in a community exhibition to draw attention to generational and gendered interests of community members. In the Thai community, 41 farmers, 19 of whom were women, participated in the focus-group discussions, and in the Hmong community, 41 farmers participated in the discussions and 16 in the photography activity. Further details on the methods used in this study are described in ICRAF guide for facilitators (World Agroforestry 2017). 


\section{Results}

\subsection{Assessment of benefits for women from participating in AFLi exemplar landscapes}

\section{Highlights}

- Participation in training improved women's perceptions of agroforestry benefits compared to women not involved in the project.

- Higher percentage of women participating in the exemplar landscape were willing to expand agroforestry systems than women not involved in the project.

- Women's teamwork, public-speaking skills, decision-making skills and confidence were enhanced through the project's activities.

- Women learned useful knowledge from the project's activities, such as agricultural techniques, for example, grafting, market knowledge and control of pests and diseases.

- Women were more willing to disseminate knowledge within communities through formal and informal channels than men.

\subsubsection{Women's perception of agroforestry benefits}

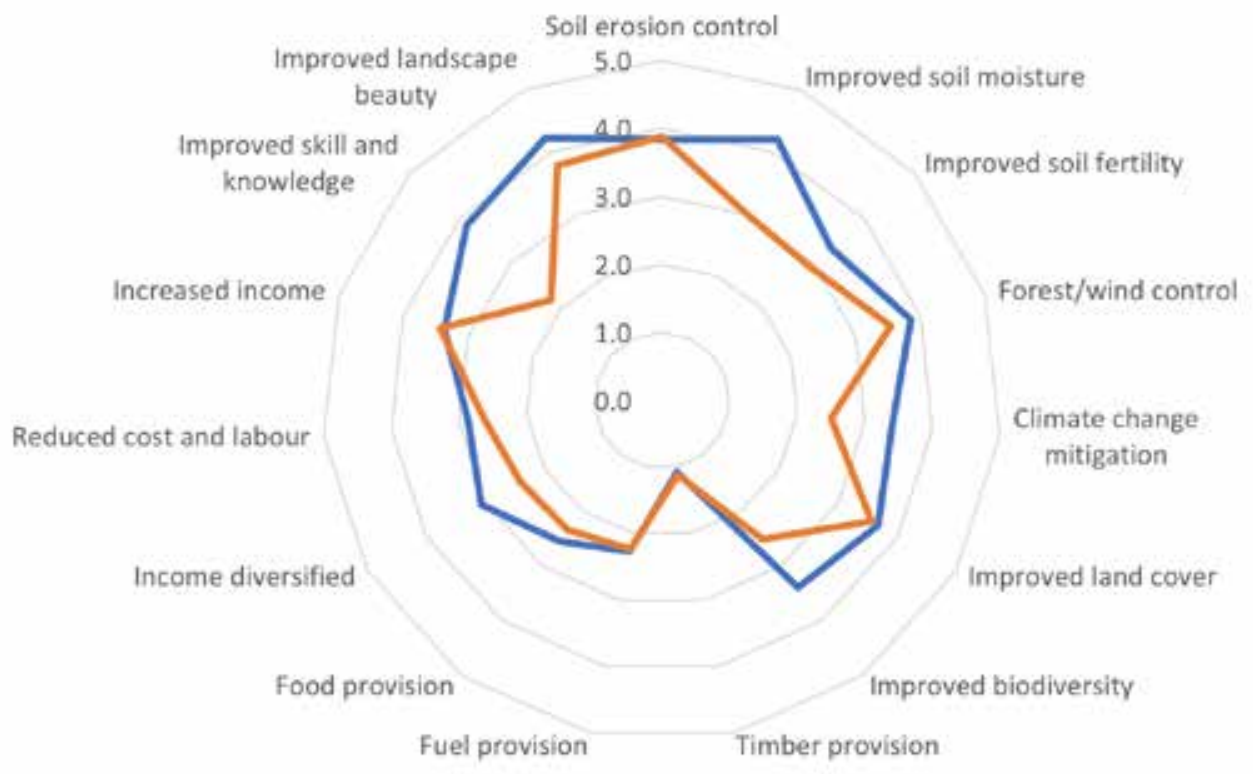


Compared to female farmers not involved in the project, women participating in the AFLi 2 exemplar landscape gave higher scores for agroforestry benefits, such as improving soil moisture, mitigating climate change (by reducing impact of extreme weather), improving biodiversity, providing food and improving knowledge and skills. The source of their information mainly came from observation of the project's agroforestry systems or their own or others in their village.

\subsubsection{Improved knowledge and skills through training and project material}

\section{Participated in project training activities \\ Participated in project nurseries Willing to share project knowledge}

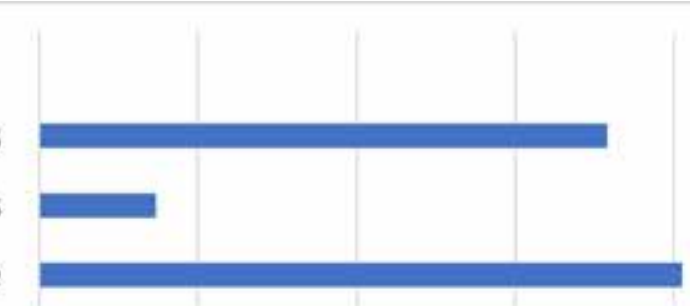

\section{$0 \% \quad 20 \% \quad 40 \% \quad 60 \% \quad 80 \% \quad 100 \%$}

Figure 4. Impact of training activities on women

*Note: $\mathrm{n}=95$

Technical support was provided to farmers through training in agroforestry system establishment and management, grafting techniques and nursery management. Almost $70 \%$ of female farmers participated in training activities yet only $20 \%$ participated in nursery activities. According to the survey results, nursery management - including seedling production, making seedling bags, grafting, taking care of the group nursery - were considered difficult skills. Men were often the preferred ones to participate in these activities.

Nearly $80 \%$ of women showed willingness to share their knowledge with family members, neighbours and friends in their villages. The main benefits from training included learning tree-management techniques, application of fertilizers, watering, grafting techniques and pest management. In Hat Lot, farmers learned about product harvesting, packaging and marketing. Women wished to have more training, specifically, on fruit-tree management and control of pests and diseases.

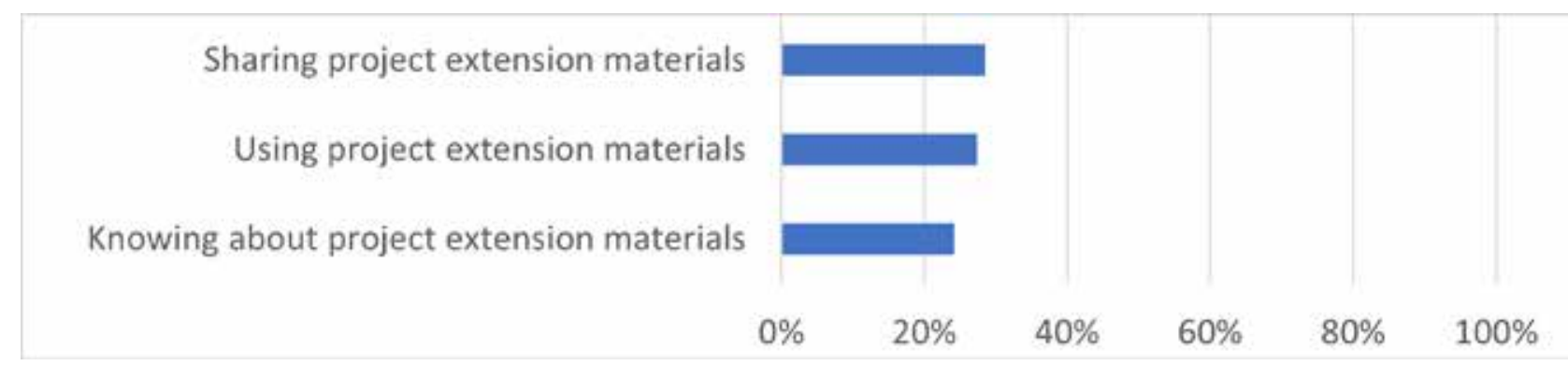

Figure 5. Impact of extension material on women

*Note: $\mathrm{n}=95$

The use of extension material remained low across all exemplar landscapes. Farmers who had newly joined in the project's phase 2 (the new exemplar landscapes) had higher rates of using, and remembering, technical material in comparison to farmers from phase 1 and farmers who had participated in earlier demonstration trials. Farmers' preferences for the format of material were for short and practical illustrated documents and videos. It was also recommended to translate training material into ethnic languages so that older people, in particular, could understand. 
The main benefits from training included learning tree-management techniques, application of fertilizers, watering, grafting techniques and pest management. In Hat Lot, farmers also learned about product harvesting, packaging and marketing.

Women indicated a strong willingness to share information with family and community members in both of the study communities. Among the six exemplar landscapes, female Thai farmers in Hat Lot and female Hmong farmers in Toa Tinh were more active than men in sharing knowledge from the project.

\subsubsection{Adoption of agroforestry options and soil and water conservation techniques}

\section{Adoption and expansion of agroforestry options}

Sixty-four percent of the women participating in the exemplar landscape were willing to expand their agroforestry system while only $46 \%$ of women involved in the project expressed their willingness to adopt or expand agroforestry systems. The reasons for not adopting agroforestry systems were mainly lack of arable land, lack of labour and 'do not like yet' (that is, they wanted to observe growth and profit from their current system first). Most of the women from the two groups wanted to grow fruit trees in agroforestry systems intercropped with seasonal crops in the first few years.

\section{Adoption of soil and water conservation techniques}

All of the interviewed women were aware of decreasing water availability, $66 \%$ observed soil erosion on their farms and its negative impact on soil quality and crop yields. None of them confirmed that they knew how to implement soil conservation techniques, including tree planting, grass planting along contour lines and terracing. The most common answer given was, 'Don't know how to do it', followed by 1) lack of management techniques; 2) lack of finance; 3) cattle damage; 4) lack of labour to manage forage grass and fruit trees.

\subsubsection{Social benefits}

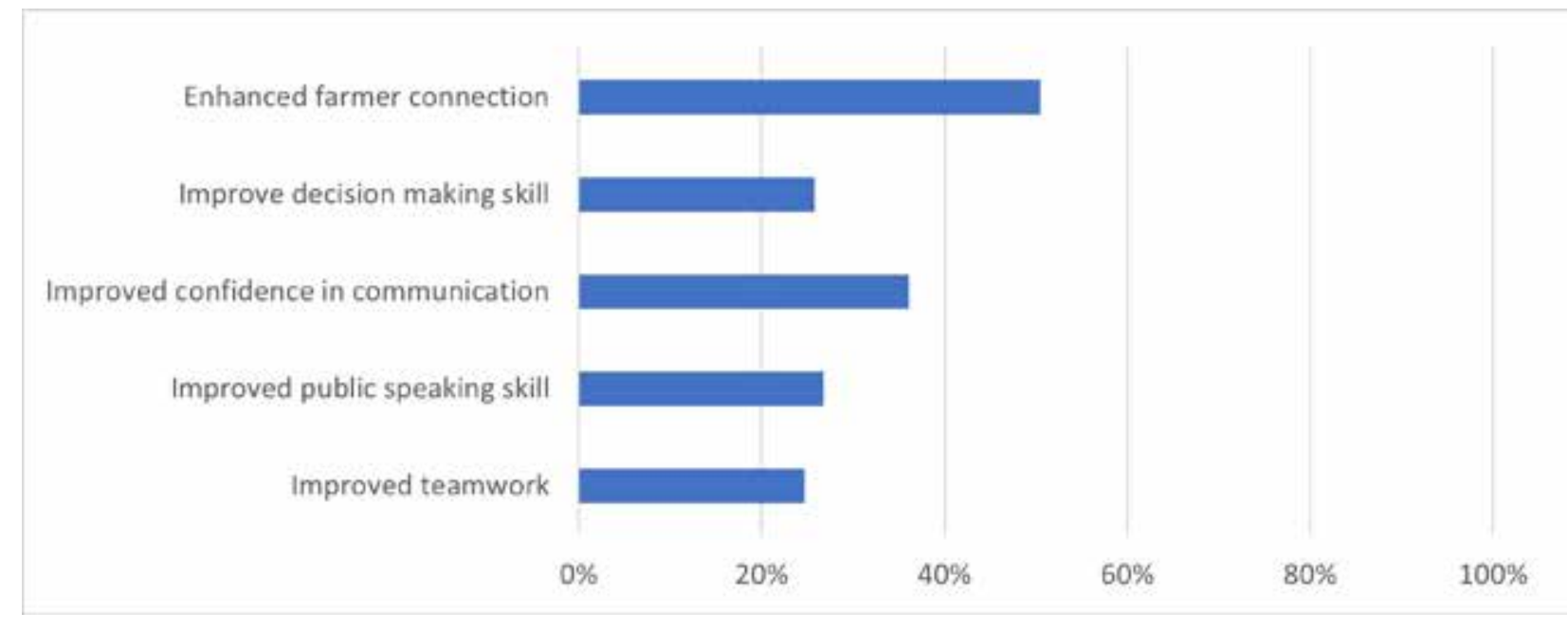

Figure 5. Impact of activities on women's social skills

*Note: $\mathrm{n}=95$

Social benefits included improved teamwork, connection with other farmers, ability to talk in public, decision-making abilities, confidence to implement agroforestry, improved techniques for tree planting, grafting and management as well as improved community forest management. A higher percentage of women having social benefits was recorded from farmers' groups participating in the 
project for longer times. Most of the women stated that they were active in farmers' groups involved with the project's activities. They often talked about agroforestry plots, the project's seedlings and selling prices of products when they met by chance in the village or visited each other. The main recognizable benefits were visiting study sites, expanding networks, and broadening knowledge and information.

Farmers learned a valuable lesson that they can broaden their group network and benefit from teamwork when everyone becomes more active in sharing information, exchanging knowledge, and solving problems together.

\subsection{Case studies from Thai and Hmong ethnic groups: the gender divide in context}

\section{Highlights}

- Thai and Hmong women have different levels of decision-making power and abilities to collaborate with men. Men, ultimately, are the primary decision-makers.

- Women are limited in their financial freedom despite being the holders of household money.

- Women participate in agricultural activities equal to men in both communities but the bulk of domestic labour falls on them, exacerbating their time constraints.

- There is a prevailing norm that assets are owned by men but women have relative freedom to use them.

- Women have some autonomy in home vegetable gardens, with small livestock and the cultivation of certain fruit-tree species.

- Nuanced community needs dictate the interests of women. Hmong women would benefit from securing better access to education and water security before being concerned with interests similar to Thai women who have better access to both.

From the overall assessment, it was clear that the rate remained low of women participating in the project's nurseries, accessing and sharing the project's material, and applying the project's soil and water conservation techniques. Therefore, we conducted the two in-depth gender studies in two communities of Hmong and Thai people (the two dominant ethnic minorities in the Northwest) to understand more deeply the roots of their issues through 'gender lenses'. We present the key findings related to gender norms, labour division, access to resources and information as well as women's constraints in adopting agroforestry techniques.

\subsubsection{Gender norms and family dynamics}




\begin{tabular}{|c|c|c|}
\hline $\begin{array}{l}\text { Thai } \\
\text { community, } \\
\text { Hat Lot } \\
\text { Commune, } \\
\text { Son La } \\
\text { Province }\end{array}$ & $\begin{array}{l}\text { Women are very involved as men in community } \\
\text { activities and are about as involved in attending } \\
\text { agricultural training. Though women use extension } \\
\text { material less than men, they are highly likely to } \\
\text { spread and receive information through informal } \\
\text { channels. Women are expected to know how to do } \\
\text { some calculations and farm techniques and actively } \\
\text { seek new knowledge, though a higher competency } \\
\text { with these activities is expected of men. Farm work } \\
\text { is carried out as a family but women bear most } \\
\text { of the responsibility of housework. There is some } \\
\text { expectation of the husband to help the wife with } \\
\text { household responsibilities and a lot of satisfaction } \\
\text { within the household when he does. Power dynamics } \\
\text { in households are changing where men were previously } \\
\text { perceived as holding the most decision-making power } \\
\text { in the family due to a prevailing norm that men are } \\
\text { the final decision-makers but the gap is now closing } \\
\text { and both genders are perceiving this shift. This does, } \\
\text { however, not control for prevailing gender norms } \\
\text { that may block women's actual ability to change } \\
\text { practices. Young women are developing a greater } \\
\text { sense of appreciation for themselves as expressed } \\
\text { by a young woman's photo of herself in the photo } \\
\text { activity to describe the person most important to } \\
\text { her. This is an encouraging finding because increasing } \\
\text { women's confidence and perceived power are ideal for } \\
\text { encouraging participation in agricultural training. }\end{array}$ & $\begin{array}{l}\text { Opportunities } \\
\text { Women's near-equal } \\
\text { opportunity to participate } \\
\text { in training and their } \\
\text { perceived decision- } \\
\text { making power indicates } \\
\text { the potential for effective } \\
\text { targeted training that can } \\
\text { influence the whole family. } \\
\text { Constraints } \\
\text { Perceived decision-making } \\
\text { power does not control for } \\
\text { all gender norms within } \\
\text { a family and therefore } \\
\text { there is no guarantee that } \\
\text { targeted training will have } \\
\text { an impact on decisions } \\
\text { made at household level. }\end{array}$ \\
\hline $\begin{array}{l}\text { Hmong } \\
\text { community, } \\
\text { Toa Tinh } \\
\text { Commune, } \\
\text { Dien Bien } \\
\text { Province }\end{array}$ & $\begin{array}{l}\text { Families do a lot of farm work together and the family } \\
\text { is central to their social values and livelihoods. Gender } \\
\text { dynamics are complex at home but it is generally } \\
\text { understood that women are responsible for the home } \\
\text { and a good husband helps out sometimes even though } \\
\text { it is not his responsibility. Decision-making power } \\
\text { is typically in the domain of men even though they } \\
\text { consult with their wives on decisions surrounding } \\
\text { sales and cultivation of products for their farm. } \\
\text { Men's perception that they have more capabilities in } \\
\text { agriculture is reinforced by the norm that attending } \\
\text { training is a man's role, so women learn new matters } \\
\text { from their husbands, exacerbating the understanding } \\
\text { that men have the final say over decisions on the farm. } \\
\text { Women's rights and power are generally perceived as } \\
\text { increasing in response to governmental campaigns on } \\
\text { women's rights, however, patriarchal power relations } \\
\text { prevail and create a barrier for women in decision- } \\
\text { making. Women are traditionally expected to support } \\
\text { their husbands, from everything to giving advice to } \\
\text { preparing tools for fieldwork, but this is changing and } \\
\text { young women clearly desire more autonomy than in } \\
\text { the past. }\end{array}$ & $\begin{array}{l}\text { Opportunities } \\
\text { Making training more } \\
\text { accessible and encouraging } \\
\text { for women to attend } \\
\text { can empower women to } \\
\text { participate and develop } \\
\text { their confidence. } \\
\text { Constraints } \\
\text { Men's drinking habits, } \\
\text { domestic violence and } \\
\text { gambling are major } \\
\text { concerns for Hmong } \\
\text { women and there is a } \\
\text { possibility that intervention } \\
\text { could create tension } \\
\text { between husbands and } \\
\text { wives. Since women do not } \\
\text { hold great decision-making } \\
\text { power in their families, } \\
\text { having men engaged is } \\
\text { critical in reaching women. }\end{array}$ \\
\hline
\end{tabular}




\begin{tabular}{|c|c|c|}
\hline & $\begin{array}{l}\text { For example, the old women's group claimed that a } \\
\text { good wife is obedient whereas the young women's } \\
\text { group stated that a good wife earns money and } \\
\text { improves her family's livelihood in addition to providing } \\
\text { her husband with good advice. Additionally, even } \\
\text { though women keep the family's money, they have } \\
\text { little decision-making power over it beyond purchasing } \\
\text { household food. The old women's group stated that } \\
\text { a good husband will purchase her clothes and gifts } \\
\text { at the market while a young woman desires money } \\
\text { to purchase these things for herself. This is a strong } \\
\text { indicator of the husband's control over the household } \\
\text { budget and women's shifting aspirations towards } \\
\text { autonomy. Figure } 6 \text { shows men and women's perceived } \\
\text { power within the family, where young women, } \\
\text { especially, see their situation as changing in response to } \\
\text { increasing levels of education. }\end{array}$ & \\
\hline & \multicolumn{2}{|c|}{$\begin{array}{l}\text { - Decisions are made jointly between husbands and wives though final decisions are } \\
\text { made by men. } \\
\text { - Women hold the money in families although they have less control over how it is } \\
\text { - } \text { - Womt outside of household food budgets. } \\
\text { - Women are interested in participating in project activities. }\end{array}$} \\
\hline & \multicolumn{2}{|c|}{$\begin{array}{l}\text { - Hmong women are less educated and so are consulted less about decisions than } \\
\text { in Thai families. } \\
\text { - Thai women are more participatory in community activities than Hmong women } \\
\text { because it is a cultural norm for Hmong men to be social representatives for families. } \\
\text { - Men participate in domestic responsibilities to a higher degree in Thai households } \\
\text { than Hmong households. } \\
\text { - Thai women have access to clean tap water while Hmong women do not. }\end{array}$} \\
\hline & \multicolumn{2}{|c|}{$\begin{array}{l}\text { In the Thai and Hmong ethnic groups, decision-making power and prevailing } \\
\text { patriarchal social structures form barriers to agricultural training for women. In each } \\
\text { case, women hold the majority of responsibility towards domestic duties, childrearing } \\
\text { and the home garden in addition to their farm duties. The project's activities enhance } \\
\text { women's social capital and confidence, contributing to their livelihoods and perceived } \\
\text { decision-making power. } \\
\text { Thai women currently have more perceived power in line with their male } \\
\text { counterparts than Hmong women but addressing the needs of each community and } \\
\text { encouraging participation in the project should be respectful of household dynamics } \\
\text { and not exacerbate tensions between family members. } \\
\text { In addition to gender norms, these communities also experience differences in } \\
\text { their levels of education and access to food and water, which have an impact on } \\
\text { the accessibility of extension training for women. Hmong women typically receive } \\
\text { lower levels of education compared to Thai women and have inconsistent water } \\
\text { security and poor road conditions for accessing markets. Women's empowerment } \\
\text { through the project's activities provides technical skills to address their constraints, } \\
\text { however, special attention needs to be paid to women's domains and their contextual } \\
\text { limitations. }\end{array}$} \\
\hline
\end{tabular}



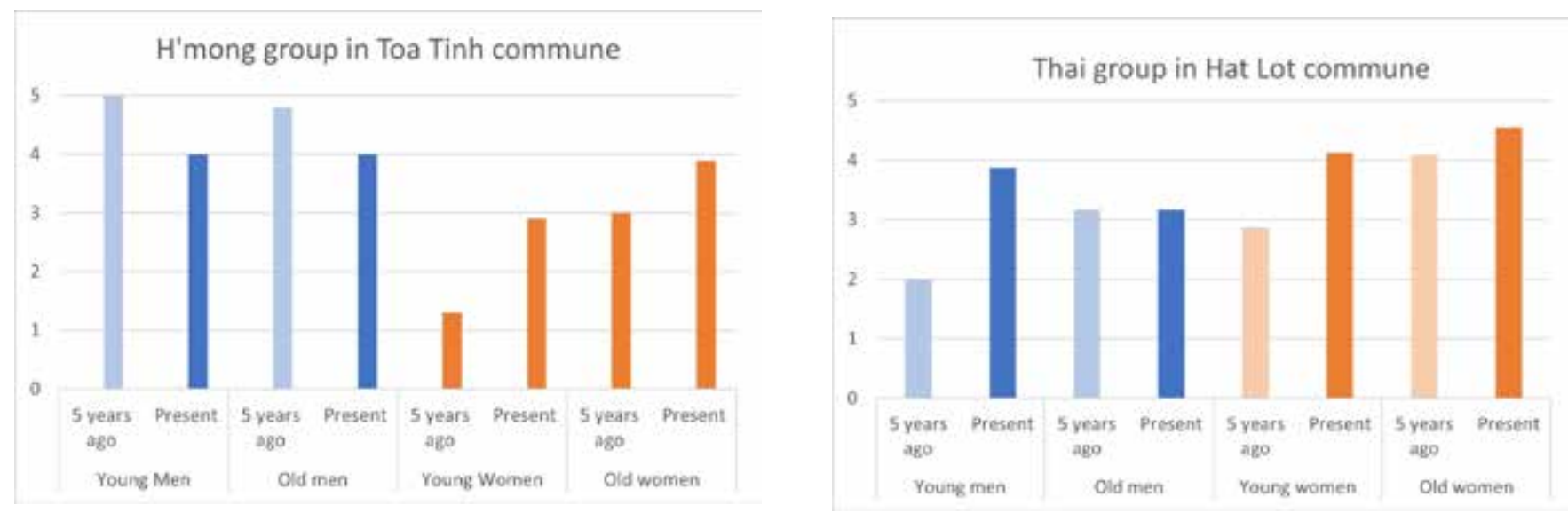

Figure 7. Men and women's perceived degree of power and freedom in the Hmong ethnic-minority community of Toa Tinh Commune

*Note: Power is on the scale of $0-5$ with 5 the most powerful

\subsubsection{Labour division}

\begin{tabular}{|c|c|c|}
\hline $\begin{array}{l}\text { Thai } \\
\text { community, } \\
\text { Hat Lot } \\
\text { Commune, } \\
\text { Son La } \\
\text { Province }\end{array}$ & $\begin{array}{l}\text { Thai women hold specific autonomous domains in } \\
\text { selling animals and vegetables at local markets and } \\
\text { are primarily responsible for foraging for, and feeding, } \\
\text { livestock and selling fruit and maize. This indicates that } \\
\text { women should have competency in calculations even if } \\
\text { they are not necessarily expected to have these skills, } \\
\text { as discussed in Section } 2.3 \text {. Men's dominant role in } \\
\text { purchasing herbicides and pesticides indicates that they } \\
\text { are more responsible for the household budget even } \\
\text { though women are generating and dictating income } \\
\text { by virtue of being present in markets and negotiating } \\
\text { with traders; a process for which they expressed their } \\
\text { concerns in the interviews because traders are known } \\
\text { to dictate prices that sellers are inclined to concede to } \\
\text { given the effort they expend in transporting products } \\
\text { to the market. Women additionally expressed a lot of } \\
\text { interest in upgrading roads and infrastructure to save } \\
\text { themselves time. }\end{array}$ & $\begin{array}{l}\text { Opportunities } \\
\text { Decision-making is likely } \\
\text { more straightforward } \\
\text { for women in their } \\
\text { autonomous domains or } \\
\text { domains in which they are } \\
\text { most responsible. } \\
\text { Constraints } \\
\text { Bad roads and } \\
\text { infrastructural constraints } \\
\text { have a serious impact on } \\
\text { women's activities and pose } \\
\text { an obstacle to women's } \\
\text { access which they cannot } \\
\text { control. }\end{array}$ \\
\hline
\end{tabular}




\begin{tabular}{|c|c|c|}
\hline $\begin{array}{l}\text { Hmong } \\
\text { community, } \\
\text { Toa Tinh } \\
\text { Commune, } \\
\text { Dien Bien } \\
\text { Province }\end{array}$ & $\begin{array}{l}\text { Hmong women do not hold specific autonomous } \\
\text { domains in any sphere although they are primarily } \\
\text { responsible for vegetable production, home gardens } \\
\text { and selling small produce at the local market. Men's } \\
\text { responsibilities include more 'heavy' duties and dealing } \\
\text { with finances and selling the higher income-generating } \\
\text { products: maize and coffee. In-the-field farm activities } \\
\text { are shared by men and women but as discussed in } \\
\text { Section 2.1, men are more present at agricultural } \\
\text { training than women due to cultural norms. Some } \\
\text { participants suggested that Hmong women are shy } \\
\text { about communicating in the Vietnamese language and } \\
\text { barter with traders and that they are not proficient in } \\
\text { performing calculations and are therefore excluded } \\
\text { from making purchases for the farm, however, the } \\
\text { labour division indicates that women are performing } \\
\text { these tasks when selling vegetables and 'son tra' } \\
\text { (Docynia indica), meaning that this perspective is likely } \\
\text { more associated with prevailing gender norms rather } \\
\text { than women's inability to do so. }\end{array}$ & $\begin{array}{l}\text { Opportunities } \\
\text { Targeting domains where } \\
\text { women are the primary } \\
\text { interested parties could } \\
\text { increase women's perceived } \\
\text { decision-making power } \\
\text { and their confidence. This } \\
\text { could increase women's } \\
\text { involvement drastically. } \\
\text { Constraints } \\
\text { Although men may not } \\
\text { participate in the labour } \\
\text { of women's domains, their } \\
\text { presence and decision- } \\
\text { making power could conflict } \\
\text { with women's autonomy. }\end{array}$ \\
\hline & \multicolumn{2}{|c|}{$\begin{array}{l}\text { - Women are responsible for small livestock, fruit and vegetable production, home } \\
\text { gardens and selling produce at local markets. } \\
\text { - Rice farming is a shared responsibility of men and women though men are } \\
\text { responsible for selling at a larger scale than local markets offer. } \\
\text { - Both communities struggle with poor road conditions affecting their daily tasks. }\end{array}$} \\
\hline & \multicolumn{2}{|c|}{$\begin{array}{l}\text { - Men and women participate in community meetings and training more equally in } \\
\text { the Thai community than the Hmong community. } \\
\text { - Thai women hold complete autonomous domains whereas Hmong women do not. }\end{array}$} \\
\hline & \multicolumn{2}{|c|}{$\begin{array}{l}\text { The project's activities provide technical skills to increase efficiency in daily } \\
\text { responsibilities and women participating in training have described the benefits } \\
\text { they received, as discussed in Section } 2 \text {. Analysis of the gendered division of labour } \\
\text { identified women's unique domains for activities, such as training that targets selling } \\
\text { animals and vegetables, and the production and selling of fruit and maize for Thai } \\
\text { women; or 'son tra' and vegetable production and selling for Hmong women. In } \\
\text { developing training procedures, domains where women hold specific interest or } \\
\text { relative autonomy over decisions that affect these domains will have the greatest } \\
\text { impact on the success of the project's activities on women. } \\
\text { The obstacle of poor road conditions was mentioned by participants in both ethnic } \\
\text { groups, in addition to the potential benefits of other infrastructural interventions. } \\
\text { Thai women mentioned their interest in irrigation systems because they are often } \\
\text { responsible for carrying water to fields whereas Hmong women mentioned their } \\
\text { household water needs because they do not have access to clean drinking water. This } \\
\text { indicates great potential for extension initiatives to include interventions that save } \\
\text { time on a daily basis and contribute to reducing women's time poverty. }\end{array}$} \\
\hline
\end{tabular}



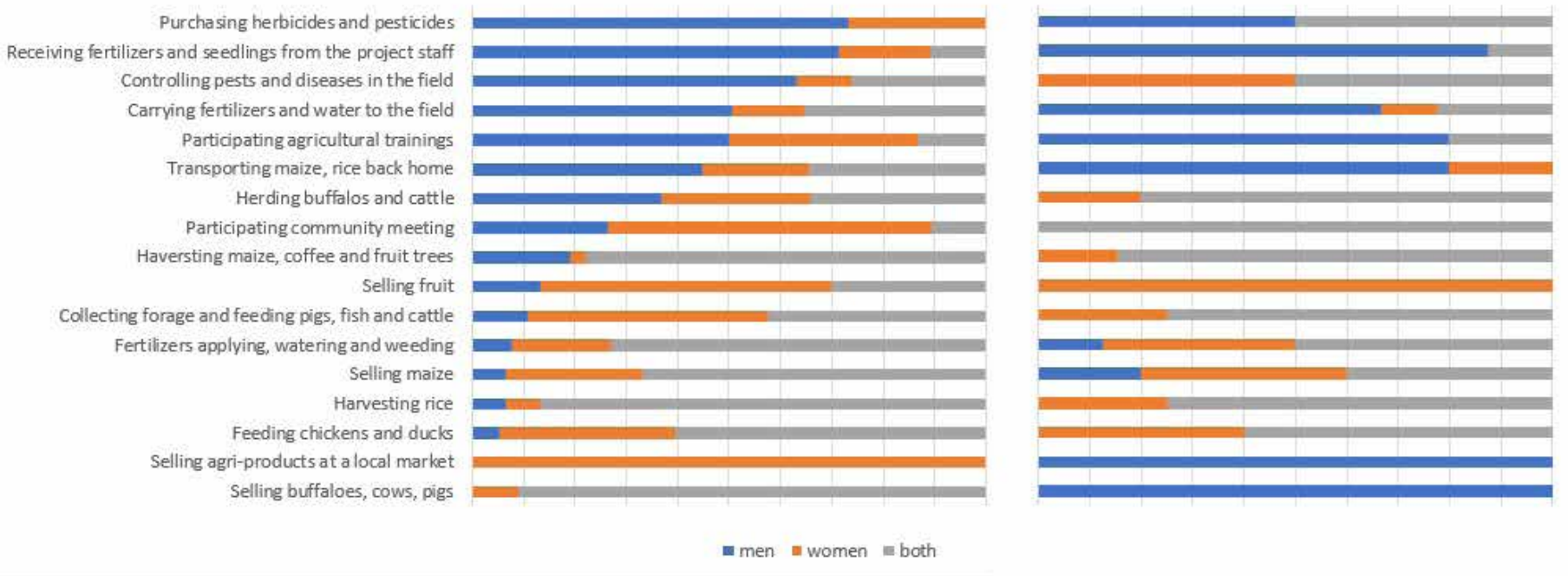

Figure 5. Labour division in Thai ethnic minority in Hat Lot commune and Hmong ethnic minority in Toa Tinh commune

\subsubsection{Time wheels}

\begin{tabular}{|c|c|c|}
\hline $\begin{array}{l}\text { Thai } \\
\text { community, } \\
\text { Hat Lot } \\
\text { Commune, } \\
\text { Son La } \\
\text { Province }\end{array}$ & $\begin{array}{l}\text { In the Thai community, men and women share } \\
\text { comparable loads of domestic and field work but } \\
\text { women's leisure time is still nearly an hour less than } \\
\text { men's. In families with young children, the husband } \\
\text { will usually help more at home but as the children } \\
\text { grow older this responsibility belongs more to the wife. } \\
\text { It is important to note that though the time wheel } \\
\text { indicated that women had } 2 \text { hours of leisure time a } \\
\text { day, almost an hour less than men's } 2.8 \text { hours, leisure } \\
\text { time does not indicate an absence of responsibilities } \\
\text { or small tasks and so cultural norms dictate the level } \\
\text { of freedom involved in this time allocation. Tasks such } \\
\text { as minding children and doing small domestic tasks are } \\
\text { associated with women's work in patriarchal societies } \\
\text { and contribute to time poverty. }\end{array}$ & $\begin{array}{l}\text { Opportunities } \\
\text { Thai women with husbands } \\
\text { who are generally helpful } \\
\text { and willing to take on } \\
\text { domestic tasks near the } \\
\text { degree of their wives } \\
\text { indicates that couples are } \\
\text { more able to work together } \\
\text { to incorporate changes to } \\
\text { their daily tasks. } \\
\text { Constraints } \\
\text { The Thai women of Hat } \\
\text { Lot Commune struggle } \\
\text { with time poverty and so } \\
\text { interventions into their } \\
\text { daily activities will need to } \\
\text { be very mindful of making } \\
\text { resources such as childcare } \\
\text { available to free up time for } \\
\text { women to take part. }\end{array}$ \\
\hline
\end{tabular}




\begin{tabular}{|c|c|c|}
\hline $\begin{array}{l}\text { Hmong } \\
\text { community, } \\
\text { Toa Tinh } \\
\text { Commune, } \\
\text { Dien Bien } \\
\text { Province }\end{array}$ & $\begin{array}{l}\text { Daily life for Hmong people involves long working } \\
\text { hours, especially for women whose work is seemingly } \\
\text { continuous. While men and women spend comparable } \\
\text { amounts of time on agriculture, women spend almost } \\
\text { three times as many hours on domestic tasks as men. } \\
\text { This loss of time means that time for eating and leisure } \\
\text { is limited for women. Men use their leisure time for } \\
\text { participating in social activities, such as drinking - } \\
\text { an integral part of their social activities - in which } \\
\text { they participate 3-4 evenings per week. Young men } \\
\text { also participate in sport. Because women have more } \\
\text { domestic responsibilities than men, it is unsurprising } \\
\text { that they have limited time to do the same. This does } \\
\text { not, however, indicate that there is no desire from } \\
\text { women to participate in sport. One young woman } \\
\text { presented a photo of archery equipment in the photo } \\
\text { activity. Time poverty is a big issue for women where } \\
\text { they are not only unable to participate in agricultural } \\
\text { training as a barrier to agroforestry but also unable } \\
\text { to invest in their own hobbies and desires. Figure } 8 \\
\text { demonstrates disparities between men and women's } \\
\text { daily responsibilities, where women have more tasks } \\
\text { allocated to daily activities outside of agriculture } \\
\text { than men. Other time poverty indicators in the photo } \\
\text { activity suggested the importance of a good, paved } \\
\text { road and proximity to it, as well as running water in } \\
\text { the home, as wishes for older women's improved } \\
\text { livelihoods. Young and old women, alike, included } \\
\text { photos of their 'dream homes' in the photo activity; } \\
\text { this is an important inclusion because it highlights the } \\
\text { importance that quality building practices and updated } \\
\text { dwellings have on women's daily activities. This was not } \\
\text { included in either of the men's groups, reinforcing the } \\
\text { lack of presence and concern they have in household } \\
\text { duties. }\end{array}$ & $\begin{array}{l}\text { Opportunities } \\
\text { Investing in agricultural } \\
\text { practices and } \\
\text { mechanisation for women } \\
\text { in this community has } \\
\text { the potential to decrease } \\
\text { women's time poverty } \\
\text { to not only provide them } \\
\text { with more time to attend } \\
\text { agricultural training but } \\
\text { also increase their ability to } \\
\text { invest time in themselves } \\
\text { for a holistic approach to } \\
\text { improving their livelihoods } \\
\text { beyond economically. } \\
\text { Since domestic work is } \\
\text { so time-consuming for } \\
\text { Hmong women, time- } \\
\text { saving practices could be } \\
\text { introduced at home in } \\
\text { addition to in the field. } \\
\text { Constraints } \\
\text { Including women in the } \\
\text { preparatory stages of } \\
\text { decreasing time poverty } \\
\text { is constrained by virtue } \\
\text { of requiring time and } \\
\text { resources to implement } \\
\text { interventions. Hmong } \\
\text { women struggle with time } \\
\text { poverty and the sharing of } \\
\text { tasks with their husbands, } \\
\text { so the burden of finding } \\
\text { time will inevitably fall } \\
\text { on them if they wish to } \\
\text { participate in agricultural } \\
\text { training. }\end{array}$ \\
\hline $\begin{array}{l}\text { Key } \\
\text { similarities }\end{array}$ & \multicolumn{2}{|c|}{$\begin{array}{l}\text { - Women and men spend nearly equal amounts of time on agricultural work. } \\
\text { - Men spend less time on domestic work than women. } \\
\text { - Women's leisure time is limited compared with men's. }\end{array}$} \\
\hline differences & \multicolumn{2}{|c|}{$\begin{array}{l}\text { - Hmong women spend more time on domestic work than Thai women. } \\
\text { - Thai men help with domestic work more than Hmong men. } \\
\text { - Hmong women sleep almost two hours less than Hmong men whereas Thai women } \\
\text { and men sleep nearly the same amount. } \\
\text { - Hmong women have no daily leisure time while Thai women have some although } \\
\text { it is still nearly one hour less than men. }\end{array}$} \\
\hline
\end{tabular}




\begin{tabular}{|l|l|}
\hline $\begin{array}{l}\text { Implications } \\
\text { for the } \\
\text { project }\end{array}$ & $\begin{array}{l}\text { Thai and Hmong women are constrained by time poverty and domestic duties albeit } \\
\text { to different degrees. Hmong farmers spend more time on agriculture each day and } \\
\text { Hmong women spend more than an hour more on domestic work than Thai women, } \\
\text { with less input from husbands than Thai families, as described in Figure } 9 .\end{array}$ \\
& $\begin{array}{l}\text { The main difference in time poverty in these two communities is that Thai women } \\
\text { receive more help and collaboration from their husbands than Hmong women and } \\
\text { so sensitivity must be paid towards not creating tension in Hmong couples when } \\
\text { working with women and keeping in mind that the burden of finding time will likely } \\
\text { be the labour of the wife. }\end{array}$ \\
& $\begin{array}{l}\text { In both communities, time-saving interventions to daily life were mentioned, such } \\
\text { as improving roads for access and including infrastructure and mechanisation } \\
\text { that will increase productivity and reduce time poverty. Although the project's } \\
\text { activities enhanced efficiency and productivity in agricultural activities, women's } \\
\text { time constraints are a significant barrier to them receiving the benefits of extension } \\
\text { services. }\end{array}$
\end{tabular}

a)
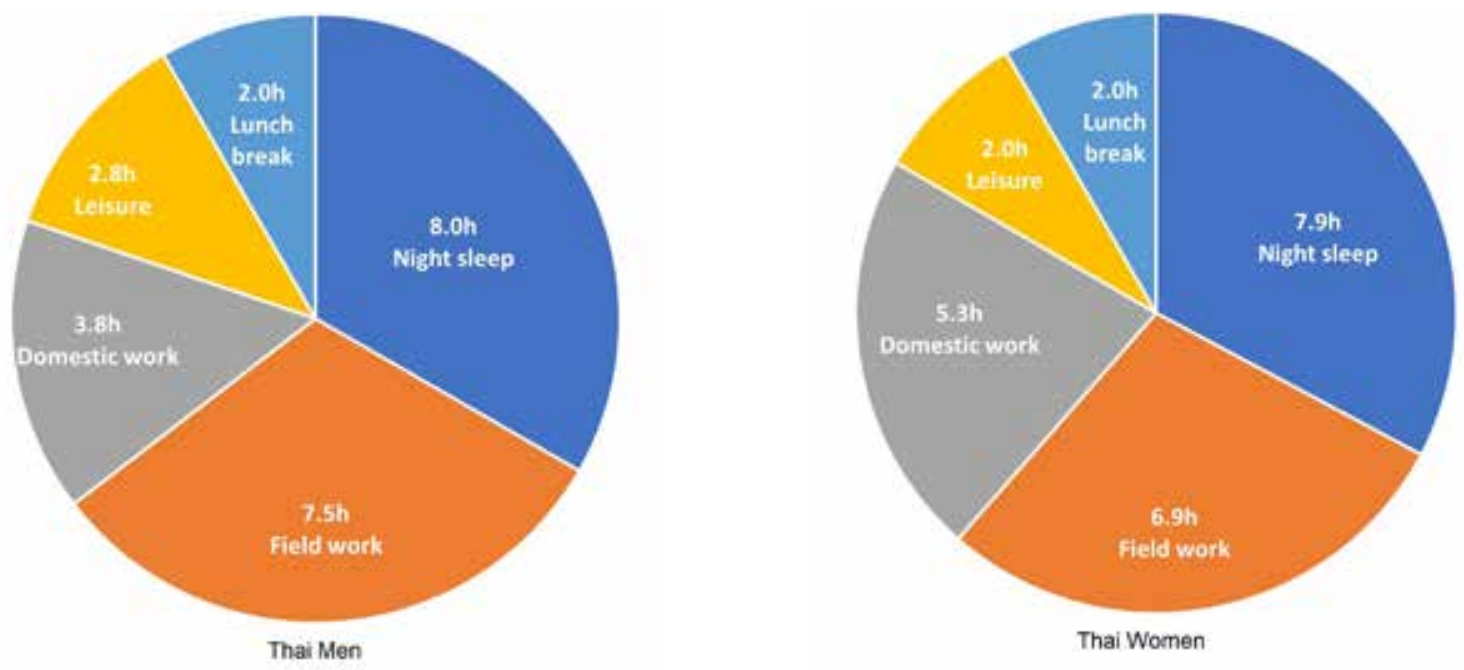

b)
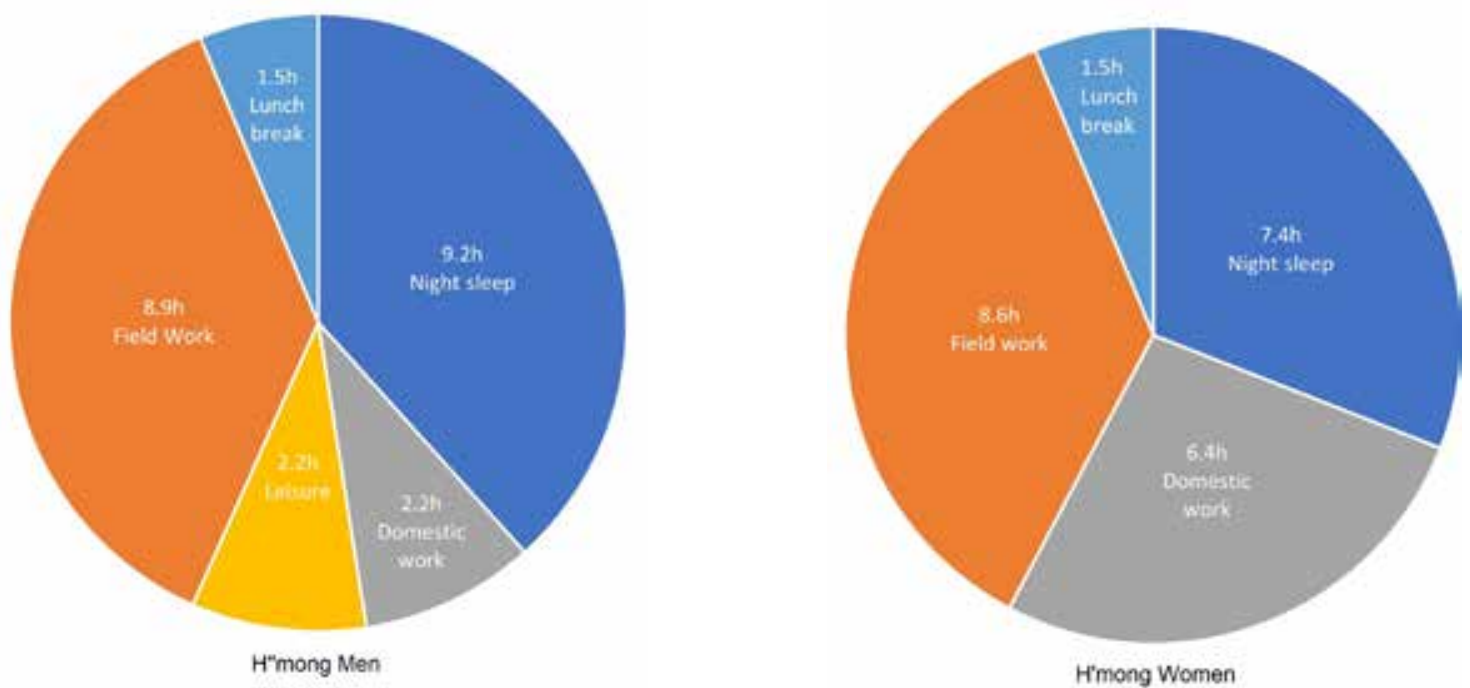

Figure 9. Gendered 24-hour time wheels

*Note: a) Thai community; b) Hmong community 


\begin{tabular}{|c|c|c|}
\hline $\begin{array}{l}\text { Thai } \\
\text { community, } \\
\text { Hat Lot } \\
\text { Commune, } \\
\text { Son La } \\
\text { Province }\end{array}$ & $\begin{array}{l}\text { The results of this analysis emphasize the highly } \\
\text { gendered distribution of resources and power dynamics } \\
\text { in Thai households, consistent with other findings of } \\
\text { this study. First, although dynamics varied between } \\
\text { households there was a tendency towards men holding } \\
\text { ownership over resources while women had relative } \\
\text { freedom to use them, which is summarized in the } \\
\text { dynamics of ownership and use of farming resources. } \\
\text { In the case of machinery, ownership of small and } \\
\text { large machinery is to a similar degree, where men } \\
\text { autonomously own this equipment more than women, } \\
\text { however, men are the sole users of large machinery } \\
\text { to a much higher degree (more than 50\%) than small } \\
\text { machinery, which is used by both genders about 75\% } \\
\text { of the time. This is consistent with women's identified } \\
\text { interest in large machinery because small machinery is } \\
\text { already much more accessible to them. } \\
\text { Though men are the perceived owners of most } \\
\text { resources, some domains exist where women have } \\
\text { more access, such as the home garden, which was } \\
\text { perceived as being owned and used almost } 50 \% \\
\text { autonomously by women, or in the case of small } \\
\text { livestock, which are perceived as very nearly equally } \\
\text { owned and used by men and women. Since these are } \\
\text { domains in which women provide most of the labour, } \\
\text { this is not surprising. Big livestock, on the other hand, } \\
\text { which men and women herd almost equally, are } \\
\text { perceived as being owned by men alone more than } \\
\text { women. } \\
\text { Information tools are seldom owned by women alone } \\
\text { though their use of these tools was much higher. }\end{array}$ & $\begin{array}{l}\text { Opportunities } \\
\text { Training women to use large } \\
\text { and small machinery is an } \\
\text { excellent opportunity to } \\
\text { reduce the time they spend } \\
\text { on agricultural activities. } \\
\text { Because they often use } \\
\text { small machinery and have } \\
\text { expressed an interest in } \\
\text { additional training for large } \\
\text { machinery, they will already } \\
\text { have some confidence } \\
\text { and competence which } \\
\text { will make these actions } \\
\text { successful. } \\
\text { Constraints } \\
\text { The results of this analysis } \\
\text { are highly gendered } \\
\text { and consistent with the } \\
\text { division of labour in } \\
\text { section 2.2. Machinery } \\
\text { training should prioritize } \\
\text { areas where women } \\
\text { are present and active } \\
\text { while also encouraging } \\
\text { their involvement in new } \\
\text { activities. }\end{array}$ \\
\hline $\begin{array}{l}\text { Hmong } \\
\text { community, } \\
\text { Toa Tinh } \\
\text { Commune, } \\
\text { Dien Bien } \\
\text { Province }\end{array}$ & $\begin{array}{l}\text { There is a tendency in perceptions that men are the } \\
\text { owners of resources and that women have equal } \\
\text { access to use them, with some variance. However, } \\
\text { this situation is changing as more young women are } \\
\text { indicating a perception towards equal ownership. } \\
\text { The results of the access to resources' breakdown are } \\
\text { highly gendered and reinforce women's roles and the } \\
\text { gendered division of labour. Since communication } \\
\text { and involvement in training is a man's role in Hmong } \\
\text { communities, combined with women's language } \\
\text { gaps, women have little access to information tools. } \\
\text { In fact, the only resource that women have complete } \\
\text { ownership of is the home garden and the only resource } \\
\text { owned equally by men and women is small livestock. }\end{array}$ & $\begin{array}{l}\text { Opportunities } \\
\text { Hmong women have } \\
\text { expressed interest in } \\
\text { training in use of small } \\
\text { machinery. This is an } \\
\text { excellent opportunity } \\
\text { to reduce the time they } \\
\text { spend on agriculture and } \\
\text { they seemingly have more } \\
\text { relative freedom to use } \\
\text { these resources. }\end{array}$ \\
\hline
\end{tabular}




\begin{tabular}{|c|c|c|}
\hline & $\begin{array}{l}\text { ce women are more responsible for labour in these } \\
\text { mains than men, this is unsurprising. However, in all } \\
\text { ler fields, men are the owners of resources, even if } \\
\text { ir use is equal. The use of agricultural equipment } \\
\text { d tools offers women much more opportunity for } \\
\text { cess compared with large machinery, which is a } \\
\text { in's domain in Hmong communities. }\end{array}$ & $\begin{array}{l}\text { onstraints } \\
\text { ccessing training is a } \\
\text { nstraint for women } \\
\text { ho have limited time } \\
\text { nd access to information } \\
\text { sources such as posters } \\
\text { dd training material. } \\
\text { ctions that support } \\
\text { omen in the use of small, } \\
\text { me-saving machinery will } \\
\text { ndoubtedly be constrained } \\
\text { y these factors. }\end{array}$ \\
\hline & \multicolumn{2}{|c|}{$\begin{array}{l}\text { - Women hold the highest rate of perceived sole ownership of home gardens. } \\
\text { - Women hold high rates of perceived ownership of small livestock }\end{array}$} \\
\hline & \multicolumn{2}{|c|}{$\begin{array}{l}\text { - Resource ownership is highly gendered, where men own agricultural equipment } \\
\text { and machines but women have relative freedom to use them, though they use } \\
\text { small equipment more than large machinery. } \\
\text { - Resource ownership is split more equally between Thai men and women than in } \\
\text { Hmong families where men are nearly the sole owners of all resources except the } \\
\text { home garden and small livestock. }\end{array}$} \\
\hline & \multicolumn{2}{|c|}{$\begin{array}{l}\text { In the Thai and Hmong ethnic communities, the distribution of assets and resources } \\
\text { is highly gendered, where patriarchal norms influence women's access. } \\
\text { Since men and women in Thai communities are more equal in many spheres than } \\
\text { in Hmong communities, it is no surprise that this is the same in their resource } \\
\text { distribution. In both communities, women hold more perceived ownership of } \\
\text { resources in the domains in which they are responsible, such as in the home garden } \\
\text { or with small livestock, however, the results displayed in Figure } 9 \text { demonstrate that } \\
\text { male dominance of ownership is more pronounced with Hmong family assets. There } \\
\text { is a prevailing assumption in both communities that men hold ownership of 'shared' } \\
\text { resources, specifically, land and machinery, and that women have relative freedom } \\
\text { to use them, however, social norms are a likely obstacle, especially in the Hmong } \\
\text { community where husbands and wives are less collaborative than in Thai households. } \\
\text { Access to information is a vital constraint that perpetuates the norm that men are } \\
\text { decision-makers thereby enhancing their perceived ownership, where women have } \\
\text { limited access to information and so leave final decisions to men, especially in Hmong } \\
\text { families. Additionally, language barriers in extension material and in working with } \\
\text { traders at the local market is a constraint for women who often have limited working } \\
\text { knowledge of Vietnamese and struggle with jargon in technical training material. This } \\
\text { is a barrier expressed by men and women in both ethnic groups but seems to be a } \\
\text { specific barrier for Hmong women who have the added cultural norm that men are in } \\
\text { charge of communications outside the family. } \\
\text { Enhancing women's social capital by engaging in the project's activities provides an } \\
\text { opportunity for women to utilize improved decision-making power, networking and } \\
\text { improved public communication to take more ownership of their time and resources. }\end{array}$} \\
\hline
\end{tabular}


Perceived ownership - Thai group

Farming resources (land, crops) Information tools (radio, $t v$, phone, training

Agriculture equipment, tool (hoe, saw...) Agriculture machine (tractor, truck, grinder...) Homegarden Small livestock (fish, chicken, duck) Agriculture inputs (fertilizers, herbicides, Agriculture product (crops, fruit trees...) Motorbikes

a) Financial ressources (banks, cash.)

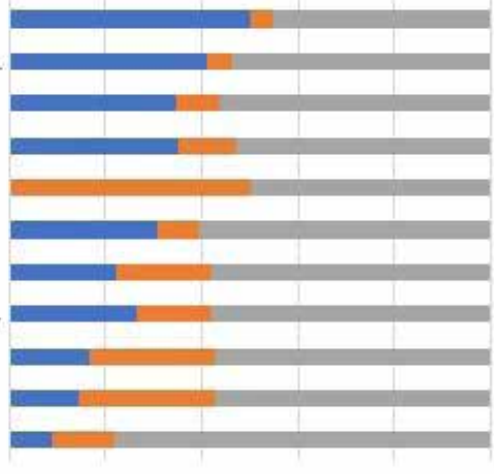

$\begin{array}{llllll}0 \% & 20 \% & 40 \% & 60 \% & 80 \% & 100 \%\end{array}$

men women wboth

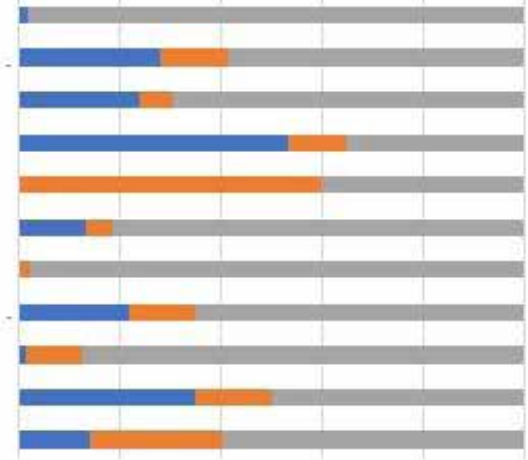

$20 \% \quad 40 \% \quad 60 \% \quad 80 \% \quad 100 \%$
Perceived ownership - Hmong group

Farming resources (land, crops) Information tools (radio, tv, phone, training. Agriculture equipment, tool (hoe, saw...) Agriculture machine (tractor, truck, grinder...)

Home garden

Big livestock (pig, buffalo, cow)

Small livestock (fish, chicken, duck) Agriculture inputs (fertilizers, herbicides,

Agriculture product (crops, fruit trees...)

$$
\text { Motorbikes }
$$

b)

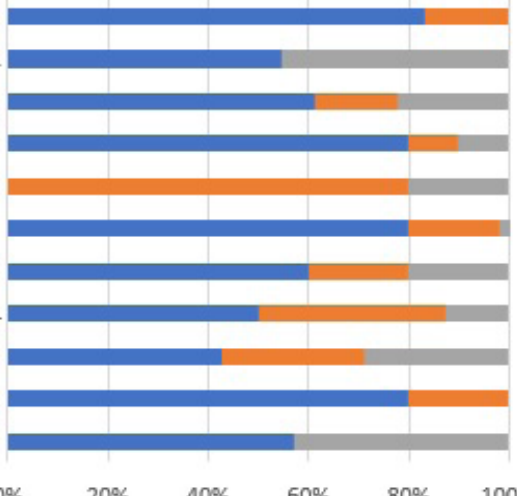

Actual user - Hmong group

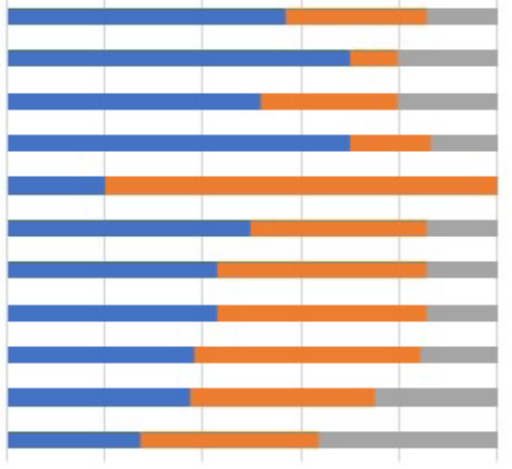

$\begin{array}{lllll}20 \% & 40 \% & 60 \% & 80 \% & 100 \%\end{array}$

men $=$ women $=$ both

Figure 10. Gendered allocation of resource ownership and use

*Note: a) Thai community; b) Hmong community

\subsubsection{Women's interests}

\begin{tabular}{|l|l|}
\hline $\begin{array}{l}\text { Thai women, Hat Lot Commune, } \\
\text { Son La Province }\end{array}$ & $\begin{array}{l}\text { Hmong women, Toa Tinh Commune, } \\
\text { Dien Bien Province }\end{array}$ \\
\hline - Grafting & - Mechanisation: small (weeding/spraying) \\
- Mechanisation: big machines (trucks/ & - Training in management of pests and diseases \\
- Farmers Union & - Son tra production and selling \\
- Infrastructure: roads and irrigation & - Livestock \\
- Fruit-tree production and selling & - Household food and water \\
- Accessible extension material & - Accessible extension material \\
- Training in management of pests and & - Roads \\
\hline diseases & \\
\hline
\end{tabular}




\section{Opportunities}

Women are aware of options that they would like to implement on their own farms and so will be able to make decisions that best suit their needs from multiple options.

\section{Constraints}

Women do not always have detailed knowledge of their interests, such as fruit-tree production and selling, which they expressed interest in learning, and so may require additional training to make educated decisions.

\section{Opportunities}

Autonomous domains, such as producing and selling son tra, are excellent opportunities for women to hold spaces where they hold decisionmaking power.

\section{Constraints}

Without a great deal of awareness of new techniques and mechanics, women are limited to possibly time-consuming and out-dated practices that may not be fit to alleviate their poverty.

\begin{abstract}
Key similarities
- Women are interested in fruit-tree production and selling and management of pests and diseases.

- Women are interested in accessible extension material with limited jargon, the use of ethnic dialects, shorter and more concise information, video training, and in-field demonstrations.

- Women are interested in improving infrastructure, such as roads

Key differences

- Thai women have higher levels of education and are freer to use machinery so they are interested in training in use of larger machinery while Hmong women are interested in training in use of smaller equipment.

- Thai women are interested in irrigation systems because they have clean tap water whereas Hmong women do not and so they are interested in obtaining this first.

- Thai women are interested in complex agricultural techniques, such as grafting, while Hmong women are interested in more basic training, such as maintaining livestock health. Both Thai men and women like planting grass, following the AFLi project's training, to reduce soil erosion.
\end{abstract}

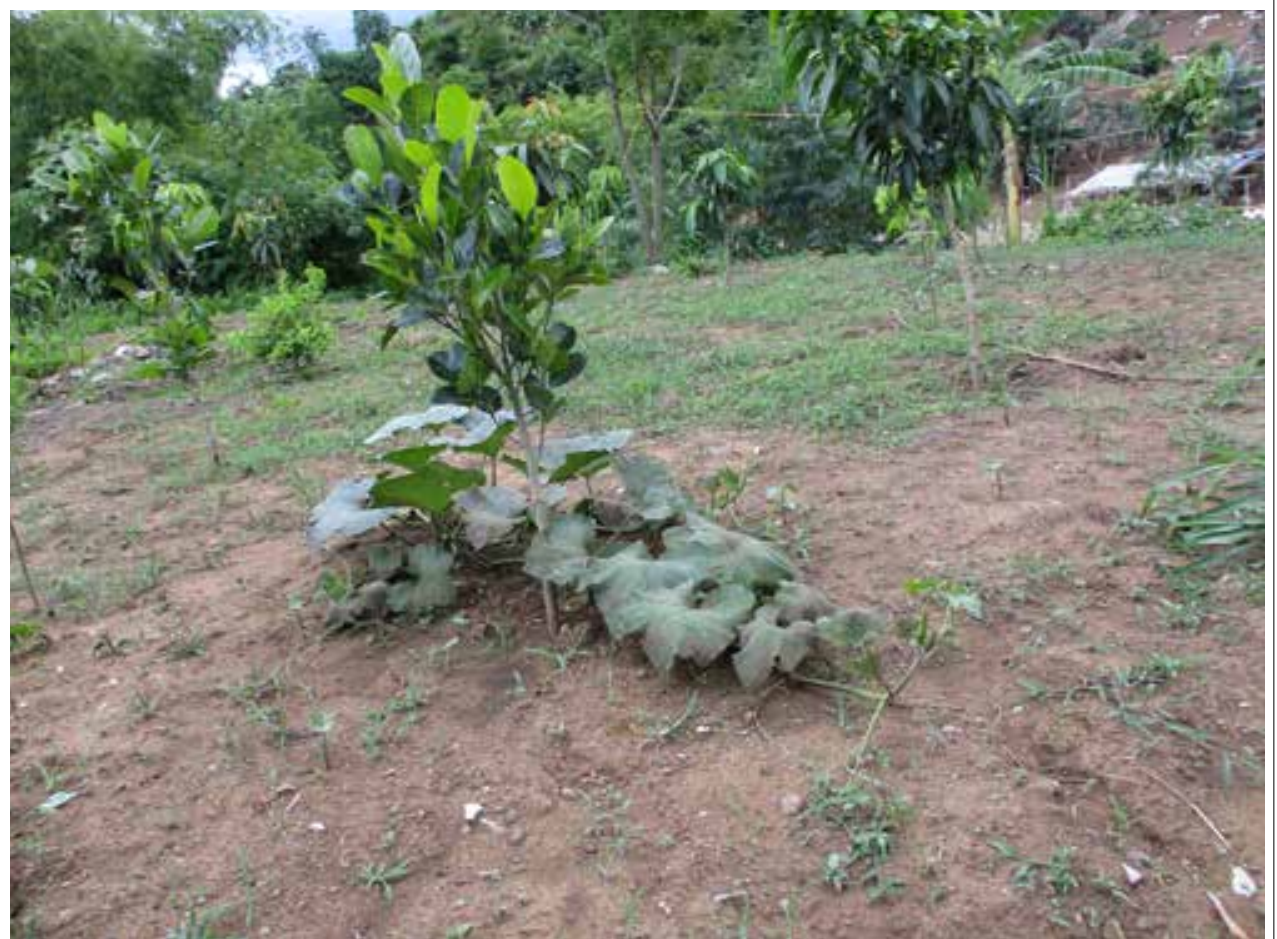

Figure 11. Agroforestry system with fruit trees and pumpkin. Photo: World Agroforestry 


\begin{tabular}{|c|c|}
\hline & 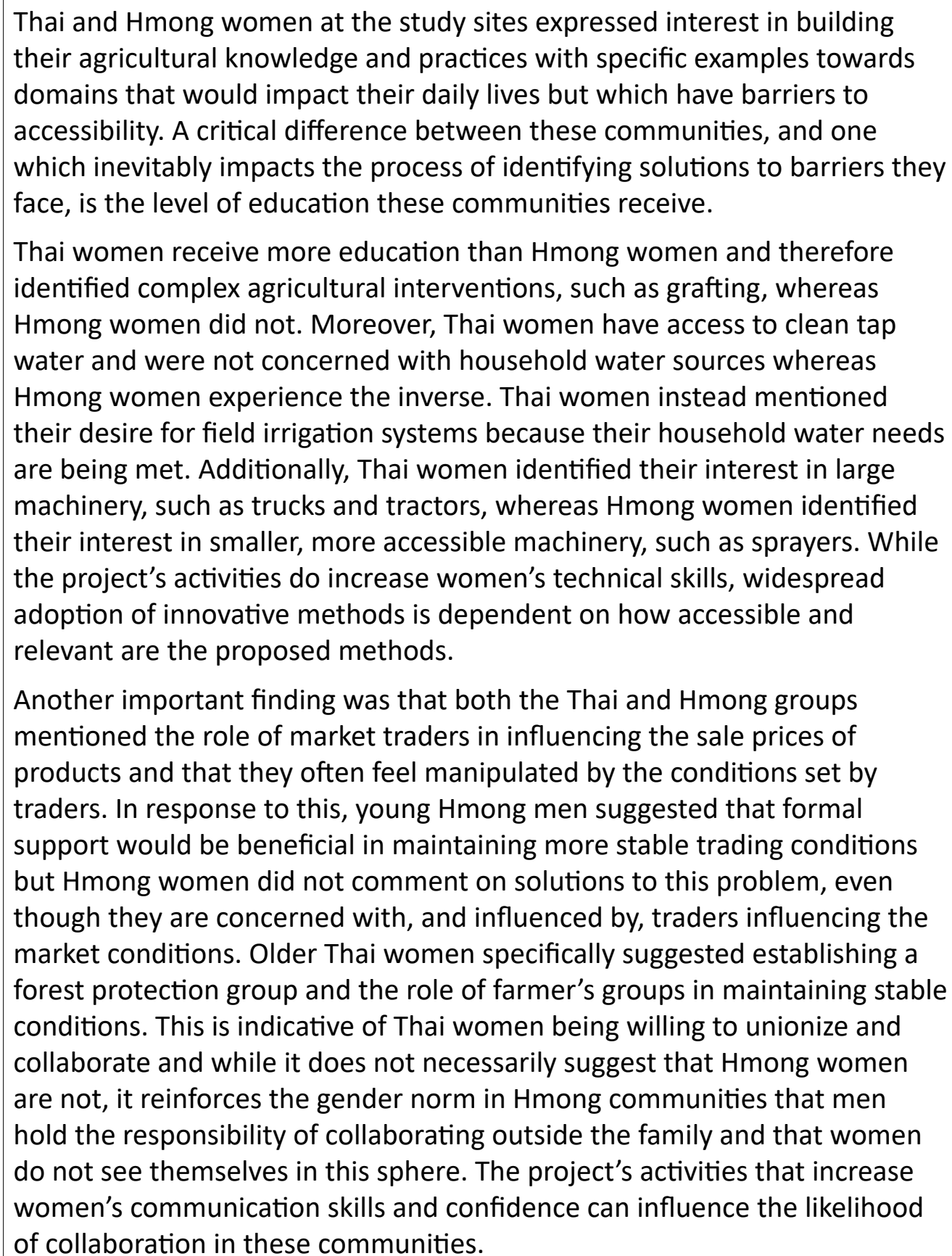 \\
\hline
\end{tabular}




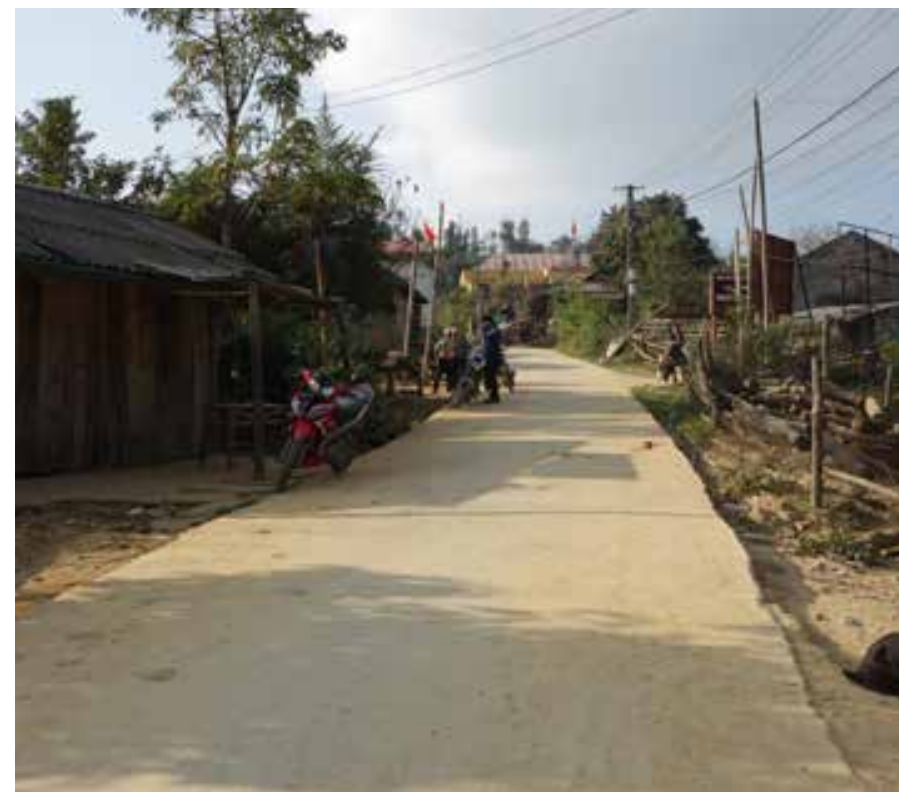

Older Hmong women like to have a paved road in their village.

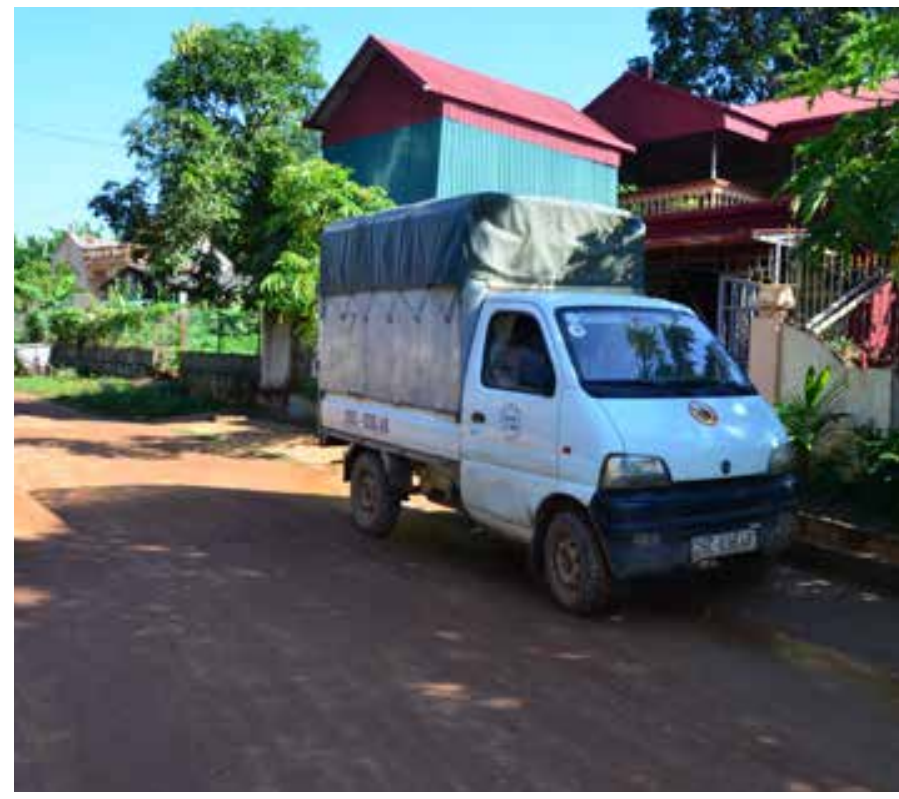

Older Thai women like trucks for doing business.

Figure 12. Hmong and Thai women's interests

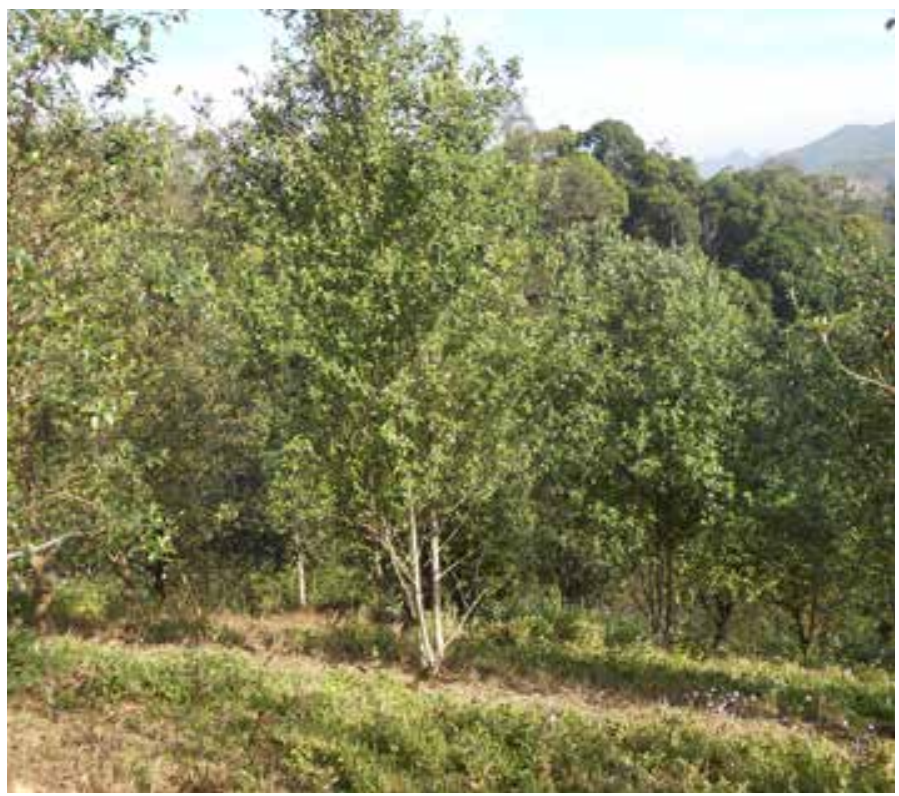

Younger Hmong women want to have good son tra tree like the ones in this photo.

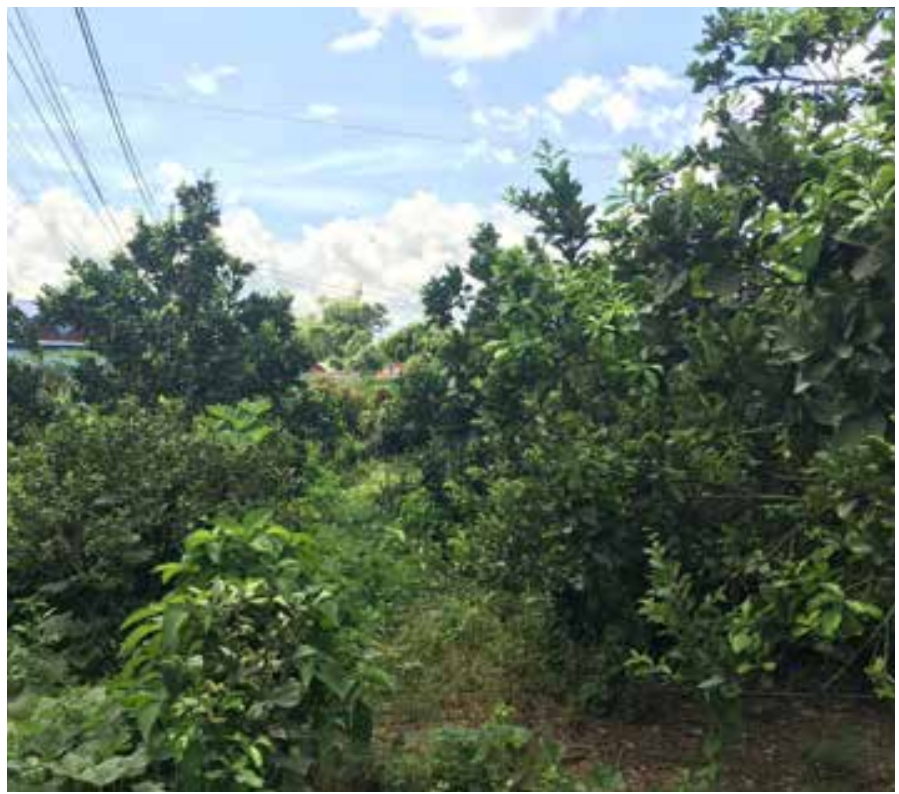

Younger Thai women like agroforestry systems to diversify their products. 


\section{Gendered constraints to project interventions: discussion}

\section{Highlights}

- Women's participation is constrained by social norms, time poverty and relative decision-making power.

- The project's activities need to respect women's time constraints, language abilities and domains of labour.

- Women disseminate knowledge through informal channels more so than men.

- Utilizing women's networks of collaboration can help the project reach more community members.

\subsection{Women's involvement in the project's activities}

Women face barriers to adopting new farming practices that are different from their male counterparts in any patriarchal society and this is absolutely the case in the Thai and Hmong ethnic minorities in Viet Nam. People in these communities, as a whole, are limited in their access to resources but a critical resource that is severely restricted, especially for women, is time. The gendered decisionmaking structure, labour allocation and access to resources sees women with very little autonomy and even less time to incorporate changes to their daily activities. Extension services that seek to include women specifically must take this into consideration when designing a project's activities.

In the Thai and Hmong communities under study, women's access to resources and decision-making were limited by common factors reported in other contexts, such as Kiptot \& Franzel's (2012) review in Africa, including land tenure, household dynamics, access to finance, labour, education, extension staff, lack of technology, local customs and decision-making dynamics. Intra-household decisionmaking power not only dictates how final decisions are made but also the ease with which women can make changes to their daily activities. In the Thai ethnic community, husbands and wives collaborate in making decisions though the husband generally has the final say; a finding consistent with Catacutan \& Naz (2015) in multiple communities whose male members are advantaged in education, training and contacts whereas female community members face limitations owing to low proficiency in the Vietnamese language and limited time due to their childcare tasks.

Though this varies within individual households in the Hat Lot Commune, women in this community, especially the younger generation, are more educated and their opinions are increasingly respected and heard. This contrasts with the Hmong group as even though men and women perceive their decision-making to be collaborative to some degree, the women are disproportionately less educated and therefore decision-making power is left to the husband; a power dynamic which, in addition to the effects of pervasive alcoholism and domestic violence in the community, affects women's confidence and empowerment in decision-making.

The prevailing sense of men's dominance over decisions and resources is reflected in each community's division of perceived ownership of resources, where Hmong women only hold dominant or equal ownership over the home garden and small livestock; domains which are almost completely their own in terms of labour expenditure. Thai women hold equal or autonomous ownership of the same domains as Hmong women. However, ownership of shared resources is split more equally in this community. Decision-making power is a key determinant in women's ease of involvement in the 
project's activities because this not only determines women's power to implement what they have learned, financially and as decision-makers, but also to re-schedule activities to accommodate women's commitments.

Women's domestic responsibilities are a drain on their time and ease of access to extension material. In both the Thai and Hmong communities, women invest an equal amount of time in agricultural activities as men in their daily lives but have less time due to their domestic responsibilities. Thai women indicated that they hold some space for leisure time in their days, which they invest in watching television or other hobbies, however, this does not necessarily indicate that their time is their own because childcare is an ongoing responsibility, one which is predominantly their own especially as their children grow older and Thai men help less and less with childcare. There is some expectation for Thai men to offer help in household domestic duties, which indicates a level of support for Thai women, however, the use of the word 'helping' by participants to describe men's involvement in domestic duties perpetuates the notion that it is a woman's duty and a man's choice if and when he participates. Hmong women are heavily constrained by domestic activities, even more so than Thai women, as Hmong men are less inclined to help. There was little indication of women's free time except for one submission to the photo activity of archery equipment and a young woman's expressed interest in this hobby. Hobbies and leisure time should be accessible to all but women face constraints due to childcare and domestic responsibilities, which are an obstacle that extends to participating in the project's activities as well. The Women's Empowerment in Agriculture Index describes the satisfactory availability of time for leisure activities as an indicator of empowerment, which women in these communities are notably lacking.

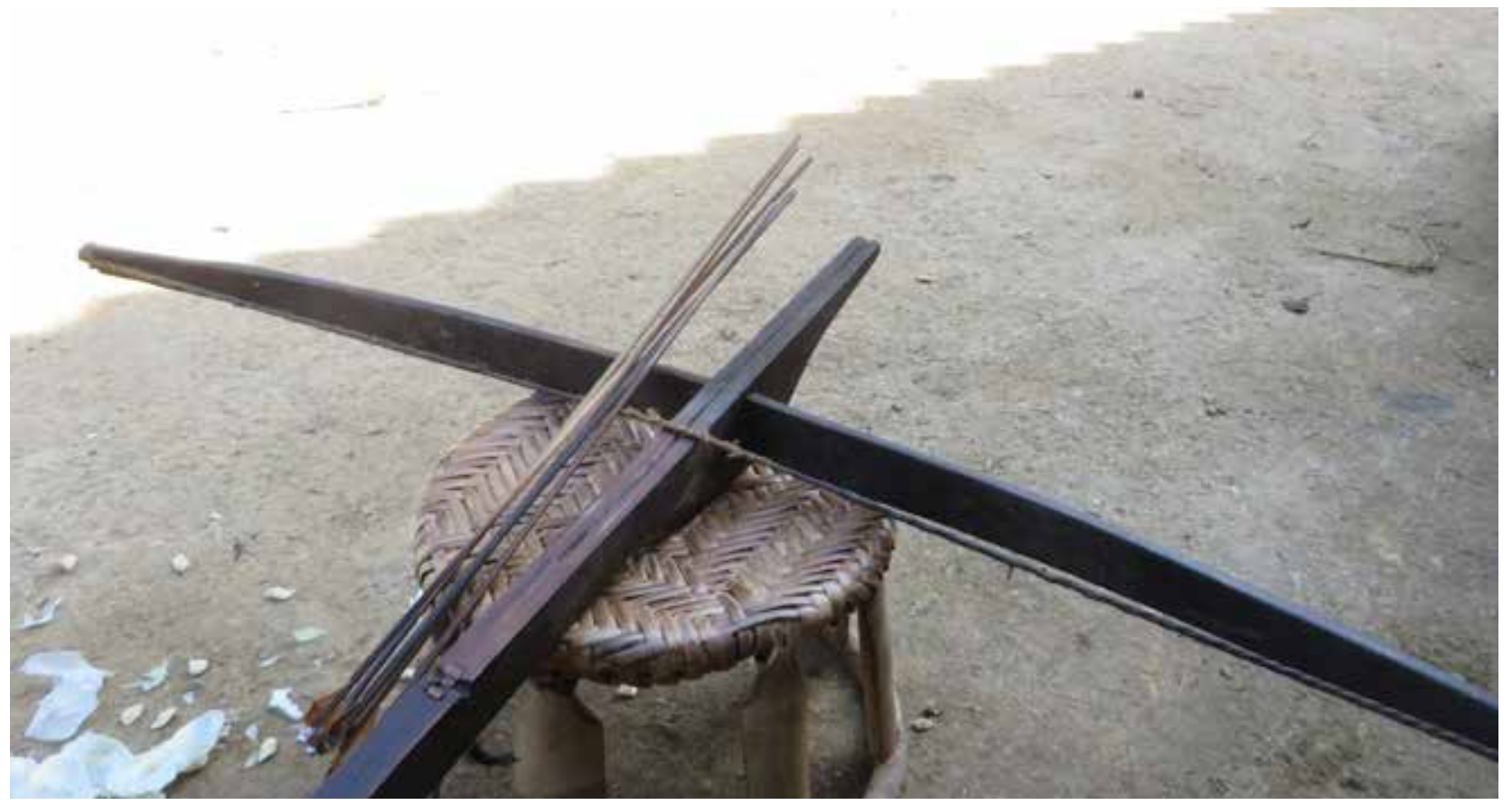

Figure 13. Young Hmong woman: 'Archery is my favourite sport. I hope I can go for competitions at district and provincial levels.' Photo: World Agroforestry

\subsection{Women's influence on the success of the project}

The project's activities are highly affected by women's participation, not least due to their channels of communication and willingness to collaborate. In the Thai community, though women did not use extension material to a high degree due to language and time constraints, nearly $80 \%$ of female participants expressed willingness to share the project's information with family and peers. Women's language barriers in the Thai and Hmong communities were similar to those reported by Catacutan \& Naz (2015), who found that ethnic-minority men in multiple contexts accessed extension information through television and radio that was presented in the official 
Vietnamese language, Kinh. Women were found to utilize informal channels of communication to obtain agricultural knowledge more than men in both communities, similar to the findings of Mamun-ur-Rashid et al (2017), indicating the potential of agricultural training to reach more community members if women are involved than if they are not. Transferring information to women will likely reach those who do not necessarily have time to participate in training and facilitating the establishment of community groups or posting information in an accessible way (including the use of appropriate language, length and visual presentation) in places where women congregate can help to effectively spread information. The role of men in disseminating information to women has been found unreliable by Mudege et al (2017), who reported that information exchange within families is influenced by power dynamics. Hmong women in the study community identified the dynamic of men being the holders of information and having their position elevated through training while women's knowledge has decreased in perceived value. Ensuring that women take on leadership roles within their communities and increasing their agency over knowledge dissemination by targeting them for training will elevate their positions in their communities; a recommendation similarly concluded by Mudege et al (2015).

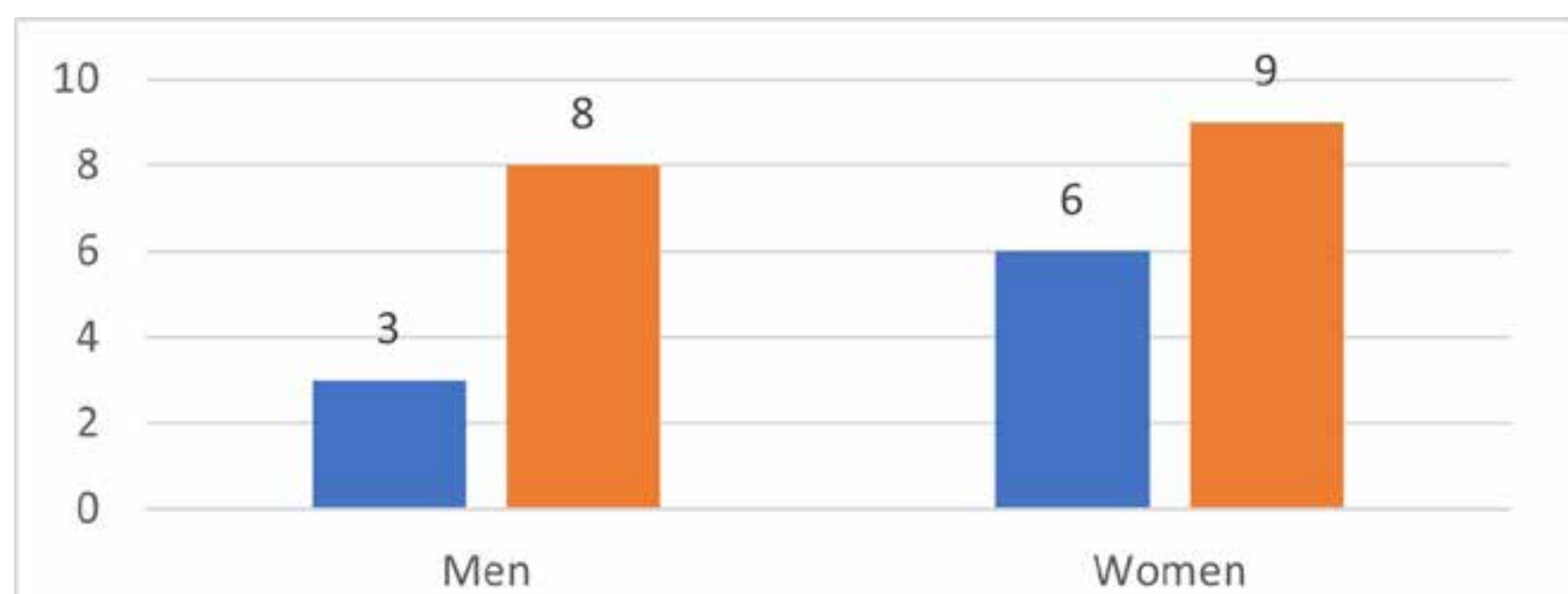

Figure 14. Number of men and women transferring project techniques to others

Women's inclusion in the project's activities is vital because they supply $50 \%$ of the agricultural labour force in the study communities. A lack of technical skills makes this investment of labour inefficient. Moreover, women have specialized domains with varying levels of autonomy and decision-making power and a lack of resources in these domains means that they are unlikely to gain efficiency. Extension staff can encourage a positive-feedback loop for women where reducing time inputs into their daily activities will lead to increased opportunities to attend training and spread information among community members. Ignoring the role of women in the agricultural labour force, and their tendency to diffuse information through informal channels, is detrimental to the success of outreach projects because it bypasses their autonomous domains and the cycle of poverty; timeconstrained and otherwise. Household technology, such as mobile phones, radio and television, are increasingly being used by extension services to disseminate information, especially, in response to the COVID-19 pandemic (Alvi et al 2021) but women reportedly have disproportionately low access to these technologies in cultural contexts outside of Vietnam (Alvi et al 2021, FAO 2019, Kiptot \& Franzel 2012, Mbo'o-Tchouawou \& Colverson 2014) as well as this study's context. Women's access to information is critical to the success of the project's activities and appropriate channels of information should be prioritised to increase their participation. 


\section{Key recommendations}

The following are key recommendations for extension staff to increase women's participation in the project's activities.

\begin{tabular}{|c|c|c|}
\hline Theme & Recommendation & Reasoning \\
\hline \multirow[t]{2}{*}{$\begin{array}{l}\text { Cultural } \\
\text { norms }\end{array}$} & $\begin{array}{l}\text { Facilitate men's involvement } \\
\text { and understanding of women's } \\
\text { roles in agroforestry adoption. }\end{array}$ & $\begin{array}{l}\text { Gendered cultural norms dictate women's } \\
\text { roles and responsibilities on the farm and at } \\
\text { home. Agricultural training that specifically } \\
\text { targets women runs the risk of creating tensions } \\
\text { between men and women who might already } \\
\text { have precarious relationships. Additionally, men } \\
\text { are the primary decision-makers in patriarchal } \\
\text { communities and so may block access to women's } \\
\text { activities if there is a misunderstanding of the } \\
\text { importance of women's roles. } \\
\text { Training should be given more frequently so } \\
\text { that women can more easily remember the } \\
\text { information, especially, in nursery management } \\
\text { to encourage women's participation in nursery } \\
\text { activities. }\end{array}$ \\
\hline & $\begin{array}{l}\text { Focus on domains where } \\
\text { women hold relative decision- } \\
\text { making power. }\end{array}$ & $\begin{array}{l}\text { Building women's confidence in their decision- } \\
\text { making skills is critical to empowerment. This will } \\
\text { be most accessible in domains in which women } \\
\text { are highly involved, such as fruit trees and home } \\
\text { vegetable gardens, or in domains where women } \\
\text { are relatively autonomous. This should also be } \\
\text { context-driven since geographical and social } \\
\text { contexts will dictate responsibilities and species } \\
\text { selected. }\end{array}$ \\
\hline \multirow[t]{2}{*}{ Accessibility } & $\begin{array}{l}\text { Design diverse, economically } \\
\text { sensitive practices. }\end{array}$ & $\begin{array}{l}\text { Access to financial resources, including household } \\
\text { monies or collateral for loans and financial } \\
\text { assistance, is predominantly a man's domain. } \\
\text { This will be dictated at household level so a } \\
\text { variety of options should be made available to } \\
\text { accommodate for individual constraints that are } \\
\text { sensitive to women's autonomous domains or lack } \\
\text { thereof. Preferential credit access should be made } \\
\text { available to women who are heads of households } \\
\text { or seeking innovation in their autonomous } \\
\text { domains. }\end{array}$ \\
\hline & $\begin{array}{l}\text { Ensure that project material is } \\
\text { accessible for all community } \\
\text { members. }\end{array}$ & $\begin{array}{l}\text { Ensuring women's use of extension material } \\
\text { and participation in training is sensitive to their } \\
\text { proficiency with the language used, their skills and } \\
\text { needs, and the presentation of material. Short } \\
\text { material that is presented in places where women } \\
\text { frequent, such as the market for Hmong women or } \\
\text { community centres for Thai women, and translated }\end{array}$ \\
\hline
\end{tabular}




\begin{tabular}{|c|c|c|}
\hline & & $\begin{array}{l}\text { into their own languages will be much more effective } \\
\text { than extension packages with large amounts of } \\
\text { wording that are time-consuming to read. An } \\
\text { additional language consideration should be } \\
\text { with local dialects where it is not appropriate } \\
\text { to assume that communities of the same ethnic } \\
\text { minority use the same jargon or colloquialisms. }\end{array}$ \\
\hline \multirow[t]{3}{*}{$\begin{array}{l}\text { Time } \\
\text { poverty }\end{array}$} & $\begin{array}{l}\text { Consider the time constraints } \\
\text { of women and propose project } \\
\text { interventions that are sensitive } \\
\text { to this and include support } \\
\text { services such as childcare in } \\
\text { tandem. }\end{array}$ & $\begin{array}{l}\text { As the primary practitioners of domestic } \\
\text { responsibilities and childcare, women are } \\
\text { constrained by time and freedom of movement } \\
\text { in patriarchal societies. The project's activities } \\
\text { should not only accommodate women's schedules } \\
\text { by offering short, regular meetings that occur at } \\
\text { different times as dictated by members of the } \\
\text { community but should also include resources to } \\
\text { assist women in addressing their responsibilities, } \\
\text { such as childcare or meal services when activities } \\
\text { overlap with meal preparation. }\end{array}$ \\
\hline & $\begin{array}{l}\text { Identify and address time- } \\
\text { consuming constraints to } \\
\text { communities. }\end{array}$ & $\begin{array}{l}\text { Women's interests in this study were closely } \\
\text { related to food, water and infrastructure to } \\
\text { varying degrees. Hmong women are vulnerable to } \\
\text { household water and food insecurity, which is an } \\
\text { obstacle to higher-level activities in the hierarchy } \\
\text { of needs. Thai women have access to clean tap } \\
\text { water but are constrained by time spent on } \\
\text { irrigation of crops. Both Thai and Hmong women } \\
\text { are negatively affected by poor road conditions, } \\
\text { which consume time in their day-to-day activities. } \\
\text { Time-consuming practices are nuanced and will } \\
\text { differ between communities but have an impact } \\
\text { on women's access to resources all the same. }\end{array}$ \\
\hline & $\begin{array}{l}\text { Implement in-field training } \\
\text { sessions with individuals. }\end{array}$ & $\begin{array}{l}\text { Teaching by doing is an effective way of ensuring } \\
\text { that women are trained in practical as well } \\
\text { as theoretical knowledge. Training in which } \\
\text { individuals are met during their daily activities } \\
\text { does not require a substantial time commitment } \\
\text { from women who are time-constrained and, in } \\
\text { the case of training for time-saving practices, can } \\
\text { reduce time spent in the field on a particular day. }\end{array}$ \\
\hline $\begin{array}{l}\text { Holistic } \\
\text { adaptation }\end{array}$ & $\begin{array}{l}\text { Implement agricultural } \\
\text { training which targets women } \\
\text { into a wider community } \\
\text { project base that addresses all } \\
\text { of women's time-poverty and } \\
\text { empowerment needs. }\end{array}$ & $\begin{array}{l}\text { Investing in agricultural training is difficult for } \\
\text { women who are time-impoverished, not least due } \\
\text { to the time commitment involved in participating } \\
\text { but also because of prevailing cultural norms, } \\
\text { education and infrastructure. A holistic approach } \\
\text { to community intervention that offers training } \\
\text { not just in agriculture but in language acquisition, } \\
\text { finance and mechanisation offers women the } \\
\text { chance to develop their sense of empowerment } \\
\text { and confidence, which contributes to a positive } \\
\text { feedback loop of increased decision-making and } \\
\text { participation in the project's activities. Additional } \\
\text { initiatives that would benefit communities and } \\
\text { reduce time-poverty are loan-support schemes and } \\
\text { investment in local infrastructure, such as roads. }\end{array}$ \\
\hline
\end{tabular}




\begin{tabular}{|c|c|}
\hline $\begin{array}{l}\text { Identify indicators of time- } \\
\text { poverty and constraints on } \\
\text { women and implement them } \\
\text { into the project's framework } \\
\text { on an on-going basis. }\end{array}$ & $\begin{array}{l}\text { Though the project's activities themselves are } \\
\text { constrained by access to resources, extension } \\
\text { services that do not provide on-going support } \\
\text { during community transformation are likely to miss } \\
\text { critical factors to women's access as they arise. }\end{array}$ \\
\hline $\begin{array}{l}\text { Encourage women to lead in } \\
\text { community development. }\end{array}$ & $\begin{array}{l}\text { Women employ informal networking channels } \\
\text { through which to disseminate information. } \\
\text { This is a unique opportunity in which extension } \\
\text { activities can encourage women to utilize these } \\
\text { channels and share information that pertains to } \\
\text { their autonomous domains and encourages time- } \\
\text { saving practices. Creating spaces where women } \\
\text { can identify their needs and collaborate with } \\
\text { other families and encouraging women to take } \\
\text { on community leadership and responsibility for } \\
\text { disseminating information in their own spheres } \\
\text { and around their schedules can empower them } \\
\text { to have confidence in their knowledge and spread } \\
\text { information effectively between themselves, } \\
\text { especially for those who do not have time to } \\
\text { attend regular training. Extension support can } \\
\text { similarly be supplied in tandem with the work of } \\
\text { existing women's associations. } \\
\text { Ensure that extension workers are representative } \\
\text { of the people they are trying to reach, meaning } \\
\text { female extension workers should be highly } \\
\text { present in women's project activities. }\end{array}$ \\
\hline $\begin{array}{l}\text { Provide adaptive training that } \\
\text { is sensitive to the climate crisis } \\
\text { and community evolution. }\end{array}$ & $\begin{array}{l}\text { Extension services need to include adaptive } \\
\text { training that is responsive to changing climatic } \\
\text { conditions, focusing on women's domains } \\
\text { and changing agricultural contexts. Adaptive } \\
\text { measures should additionally consider policy- } \\
\text { support projects to ensure women's rights and } \\
\text { empowerment from government agencies. } \\
\text { Adaptation to unprecedented situations like the } \\
\text { cOVID-19 pandemic should include measures such } \\
\text { as physically distanced training and the inclusion } \\
\text { of gender-sensitive and accessible technologies for } \\
\text { training purposes. Maintaining on-going support } \\
\text { that considers changing socio-cultural conditions } \\
\text { is highly important in ensuring continual } \\
\text { empowerment for communities. Extension plans } \\
\text { should include support services, repeat activities } \\
\text { and refresher courses, and evaluation procedures } \\
\text { to ascertain changing community contexts. }\end{array}$ \\
\hline
\end{tabular}




\section{Conclusion}

Access to resources, including time and decision-making power, is highly gendered in patriarchal societies and among the most predominant constraints on women's ability to participate in agricultural innovations, such as adopting agroforestry.

Project interventions must compensate for gendered social norms, requiring a holistic representation of women's needs, for women to be free to participate. If women's basic needs are not being met, it is unlikely and unreasonable to assume that offering services that do not accommodate women's responsibilities and time constraints will lead to widespread adoption.

The ethnic minorities of Viet Nam live on a 'ladder' of degrees of freedom that is derived from their resources and which places appropriate project activities adjacent to the needs of individual communities. Thai and Hmong women are at different stages in agricultural empowerment and access to education and resources, so intervention into these communities needs to be highly locally nuanced and community-driven. There are 53 ethnic minorities in Viet Nam differing in cultural contexts and spread among geographic contexts that affects mobility and environmental conditions between communities even of the same ethnic background.

The differences observed between the Thai and Hmong communities under study highlight the importance of cultural and geographic contexts on community-level access of just two of these communities. On-going support systems are invaluable to the success of a project's activities, including stages of re-evaluation similar to the following.

1. Preparatory stage: identify community needs and local contexts.

2. Planning stage: create a set of criteria and indicators for successful interventions and seek resources and support from government and others.

3. Support stage: begin offering supporting services (for example, finance and training services).

4. Participatory stage: implement training and livelihoods' interventions (for example, road building and water infrastructure).

5. Evaluation stage: evaluate the success of criteria and indicators.

6. Repeat $1-5$.

Further research into a framework that focuses on the stages of community transformation through a 'gender lens' in this context would be instrumental in ensuring that women are able to participate in the project's activities by ensuring that activities are sensitive to their needs and invested in their on-going education and empowerment. This goes beyond agricultural interventions and could include, for example, support in trading for those women who sell produce at markets or in language and jargon for those who are not proficient in Vietnamese. Further research into an adaptive framework that can be applied in a variety of contexts is recommended. This framework should prioritise time-saving activities for women and include material, such as a checklist, highlighting key considerations to maintain accountability among the project's support staff. 


\section{Appendix}

Information from the photo activity to understand different points of view of men and women (young and old groups) on time spent, most valuable things or persons, sources of information, challenges in cultivation and desired farming systems.

Question 1: Where do women/men spend much of their time? With whom? What do they do?

\section{HMONG GROUP}

\section{Younger Hmong men}
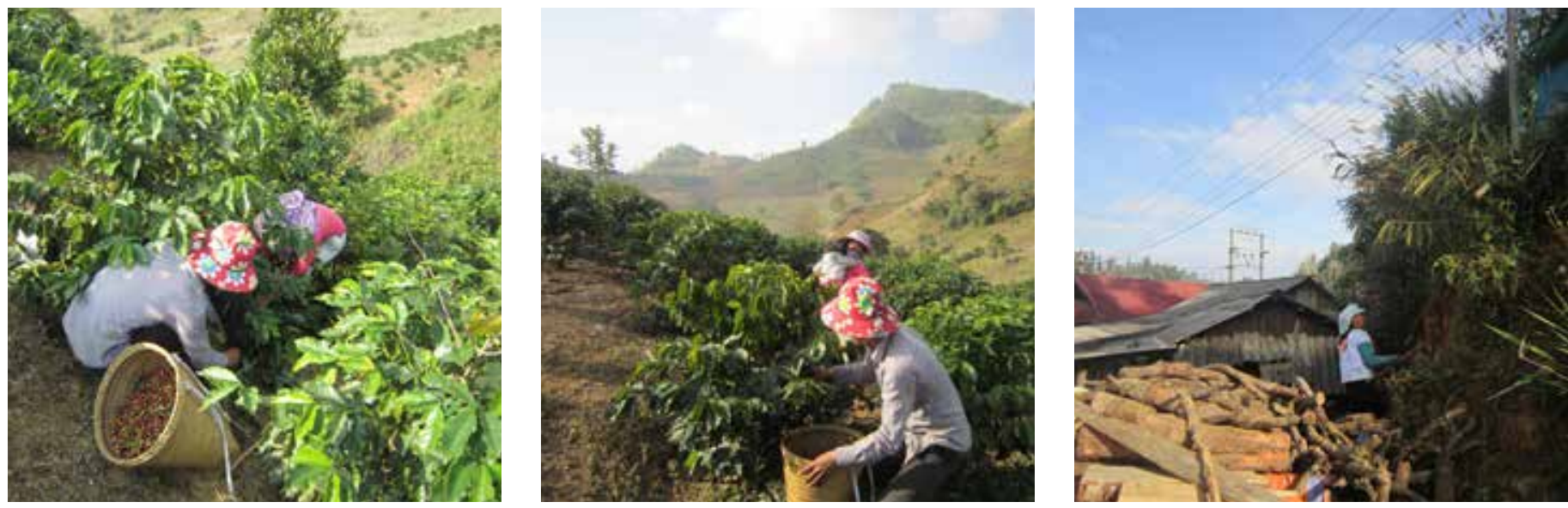

Young men spend much of their time working in the field, including harvesting coffee, weeding, spraying herbicides/pesticides, planting coffee, rice, maize, fertilizing with their family.

\section{Older Hmong men}

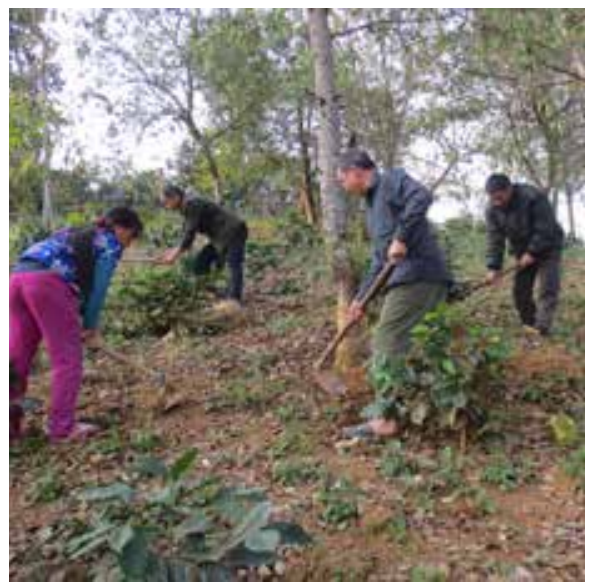

Familymembers weeding together in a son tra plantation.

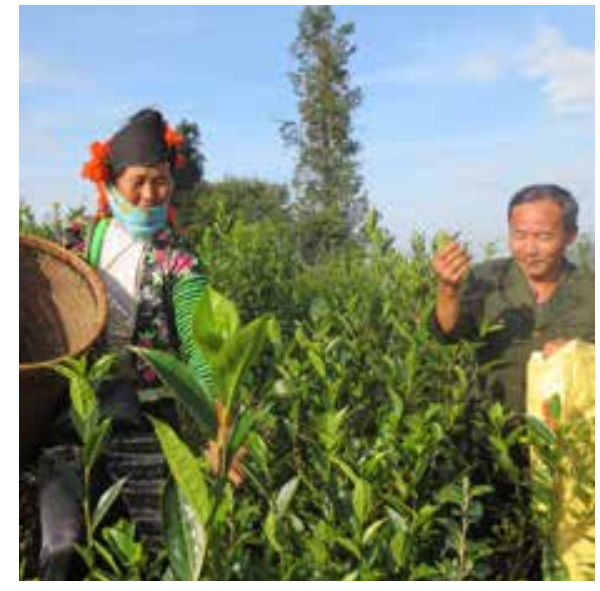

It takes a long time to harvest tea. Farmers harvest every 2 weeks and usually exchange labour with 6-7 neighbours.

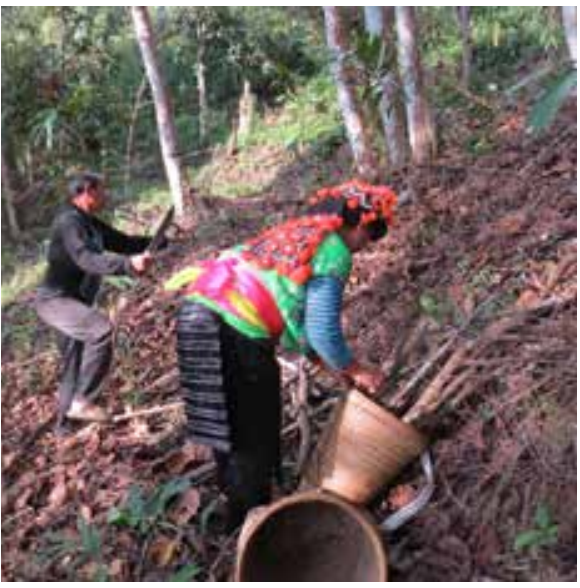

After the harvest season, husbands and wives usually go to the forest to collect fuelwood and store to use in the rainy season. 


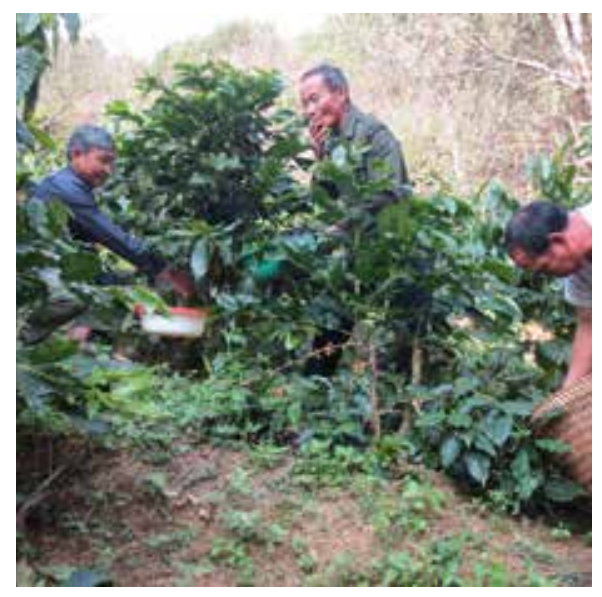

It takes farmers a long time to harvest, including coffee cherries.

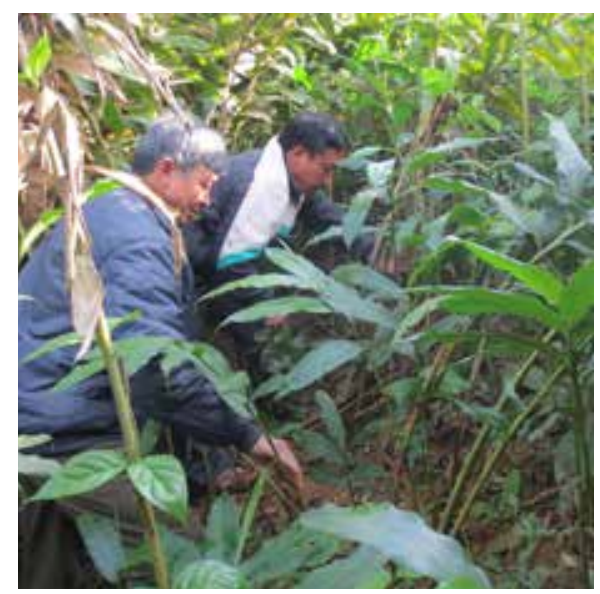

The period from July to October is the time when farmers harvest 'amomum' ('sa nhan'(Amomum spp.))

\section{Younger Hmong women}

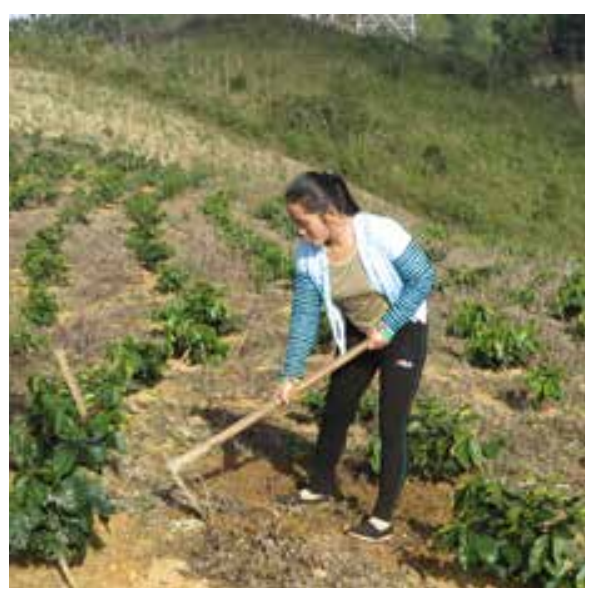

They spend most of their time in the field.

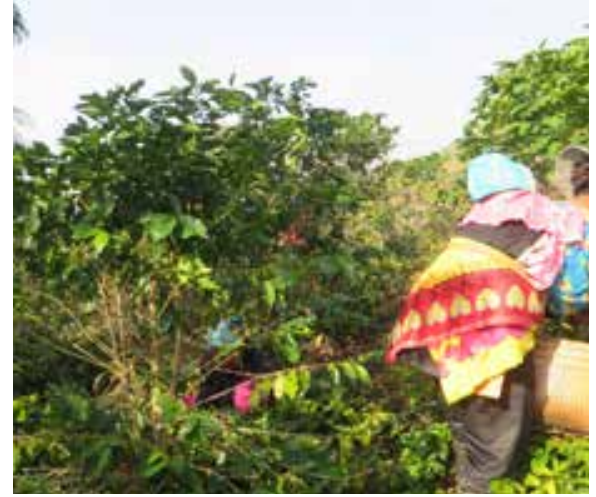

Picking coffee consumes a lot of time.

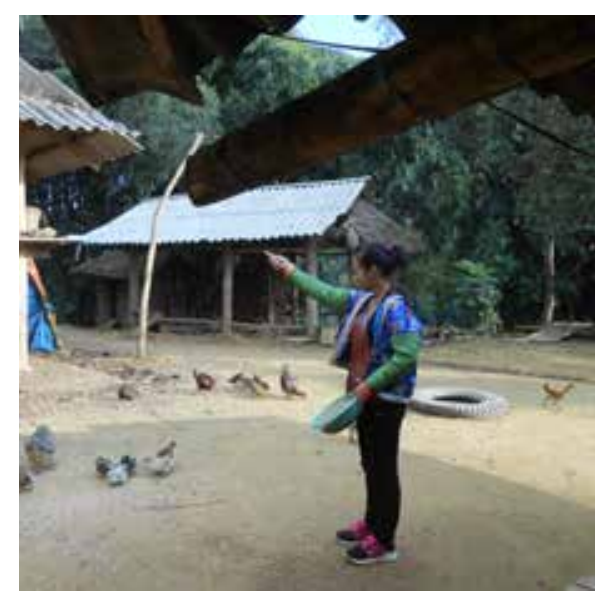

Feeding chickens also takes a lot of time.

\section{Older Hmong women}

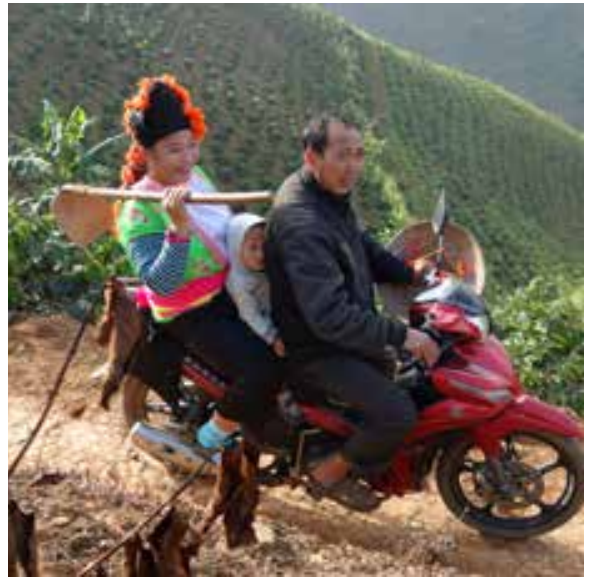

Thao and her husband are going to the fields with their grandchild.

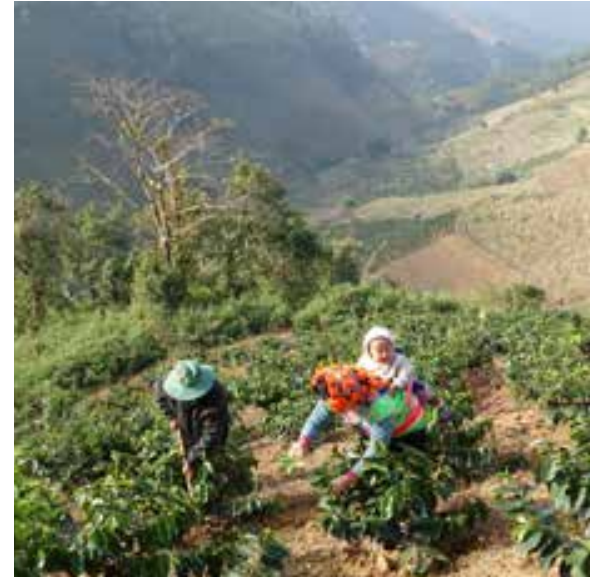

Thao and her husband weeding their coffee plot.

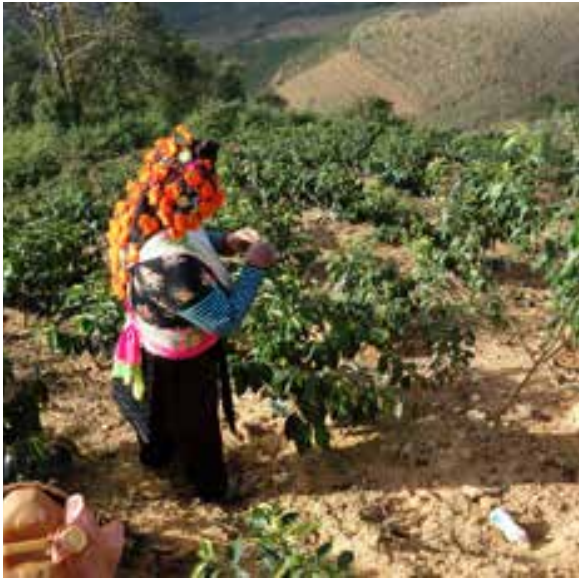

Huong checks for pests and diseases in her coffee plot. 


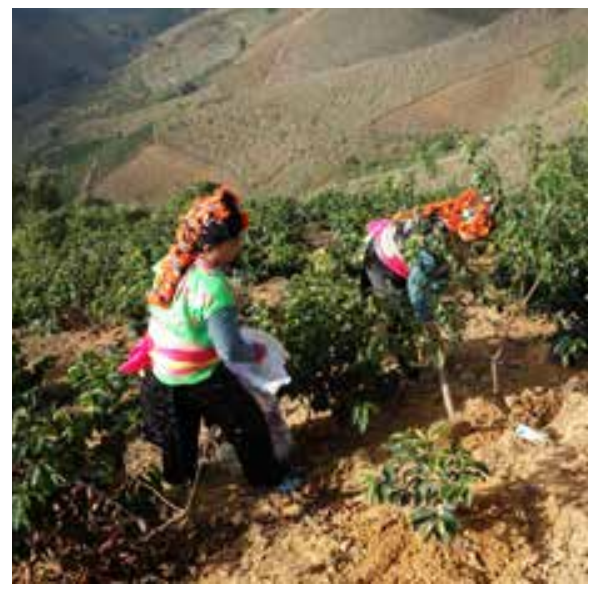

Thao and Huong apply fertilizers to coffee.

\section{THAI GROUP}

\section{Younger Thai men}

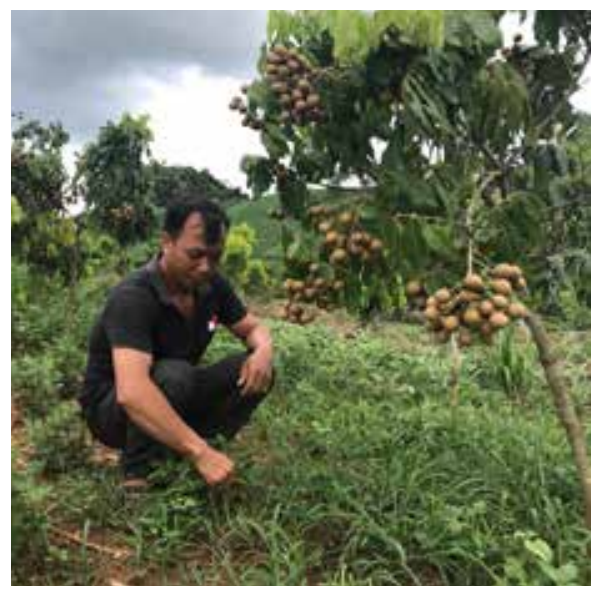

I spend most of my time in the longan garden or sugarcane plantation.

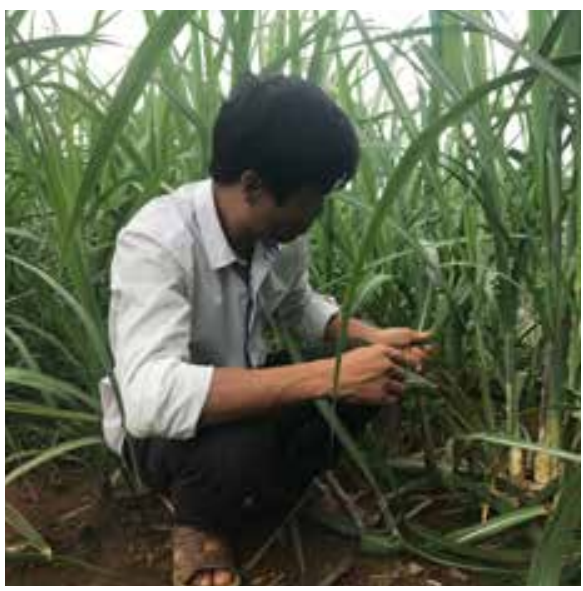

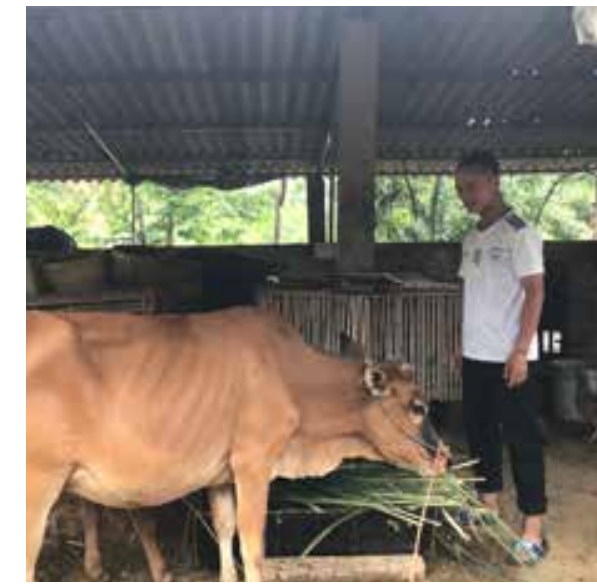

Raising livestock (cattle or chicken) takes most of my time.

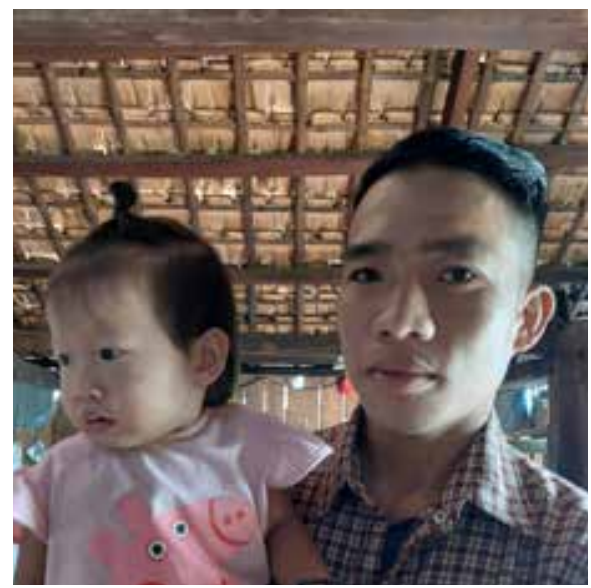

I spend time to take care of my daughter. 


\section{Older Thai men}
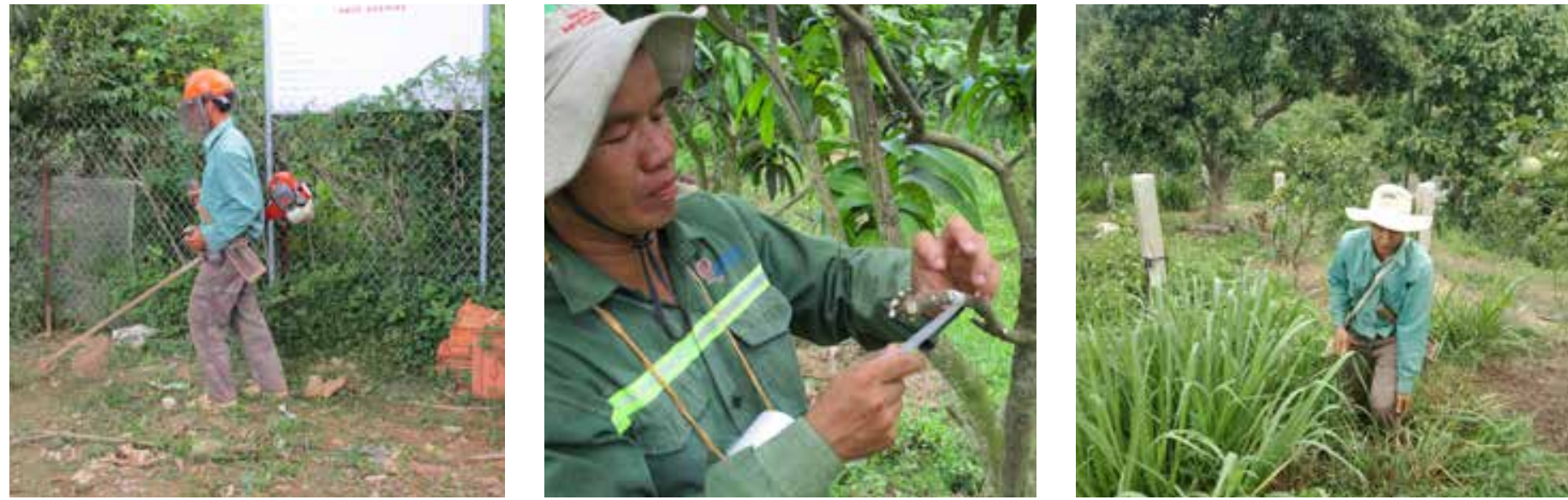

The older men spend most of their time managing their farms, such as weeding, grafting, checking and treating pests and diseases, harvesting grass.

\section{Younger Thai women}

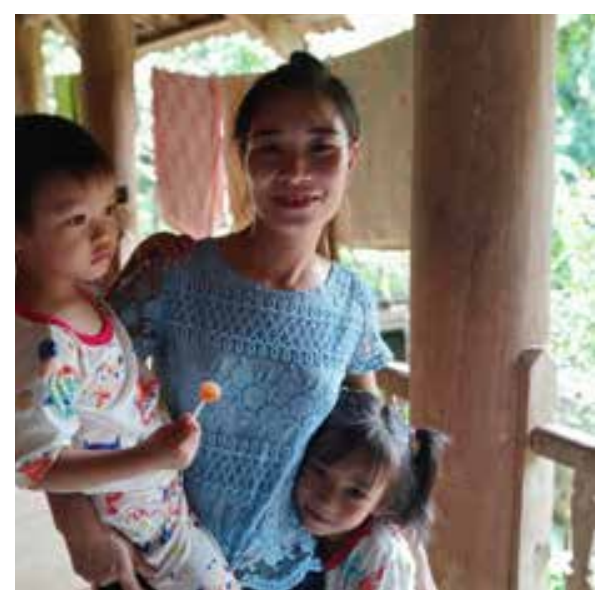

I spend most of my time taking care of the children.

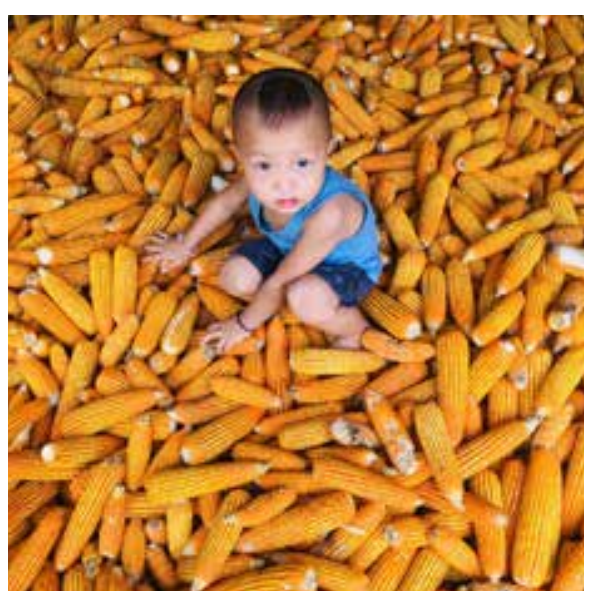

I dry the maize while looking after my child.

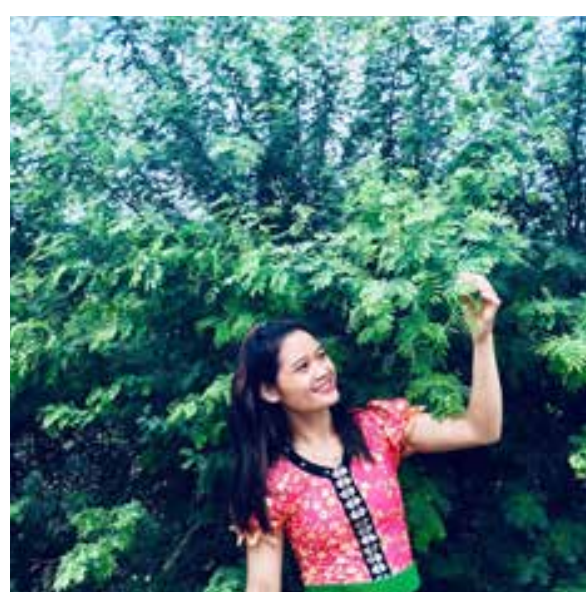

I spend time to take care of myself.

\section{Older Thai women}

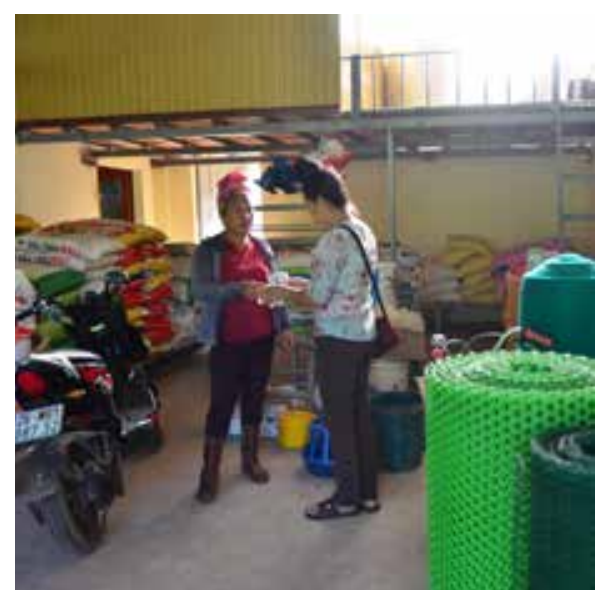

I run the input shop at home.

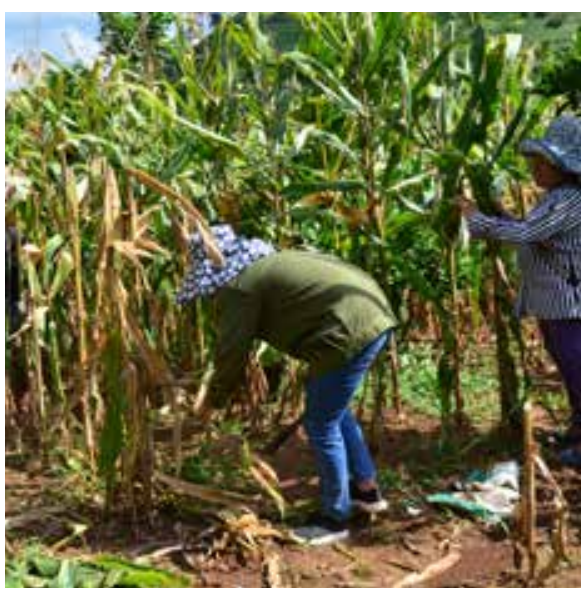

I harvest maize and manage the other fields.

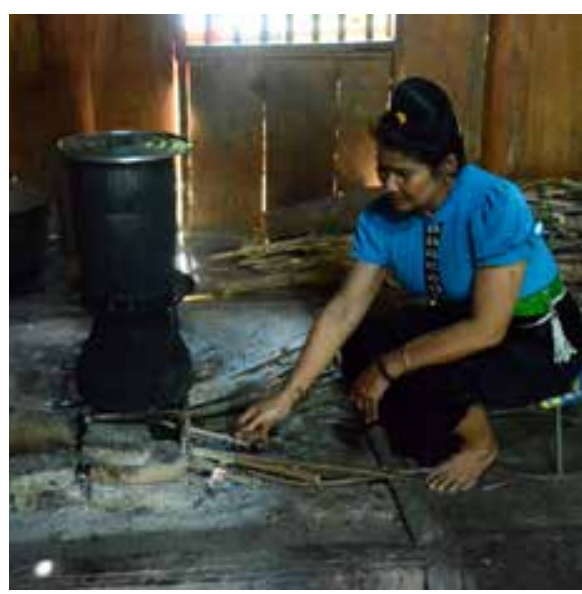

I cook for my family. 


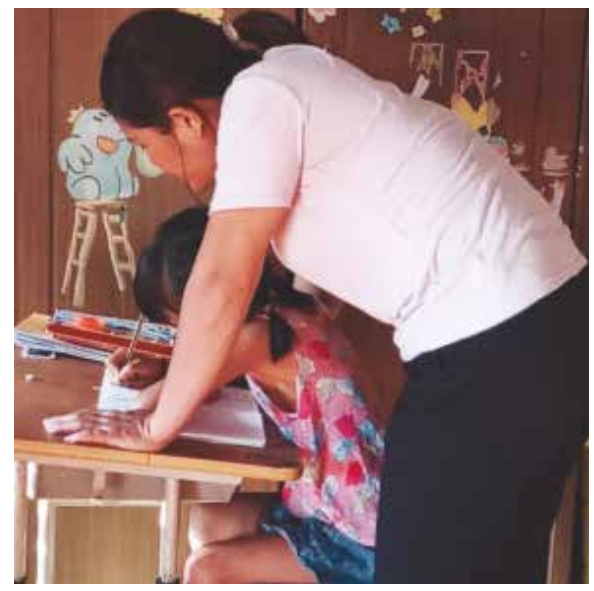

I help my children do homework.

Question 2: What are important and valuable things for women/men or who is the most important person in the Hmong/Thai group?

\section{HMONG GROUP}

\section{Younger Hmong men}

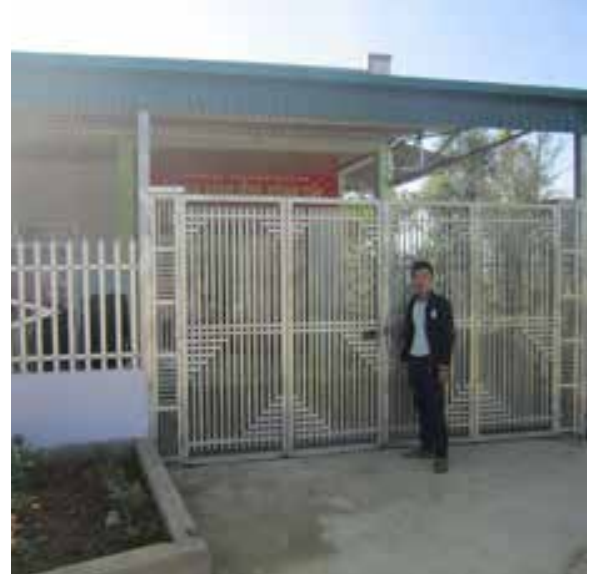

The house is important because it is the place for the whole family where they can take a rest and relax with all family members.

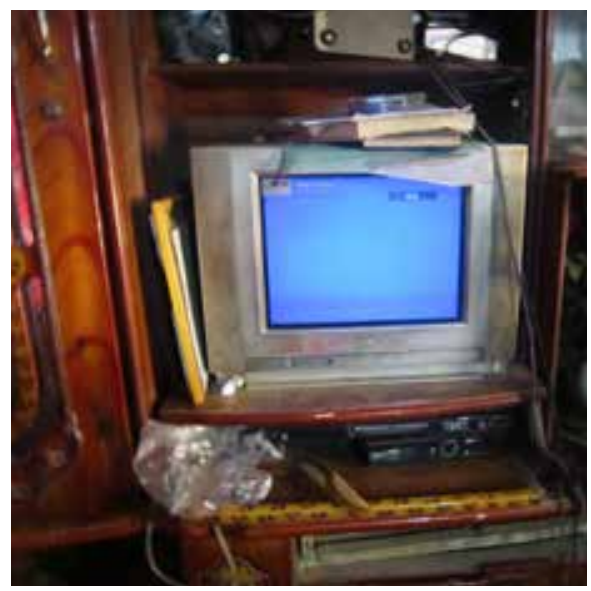

The television is important because it serves entertainment purposes and provides agricultural and technical information.
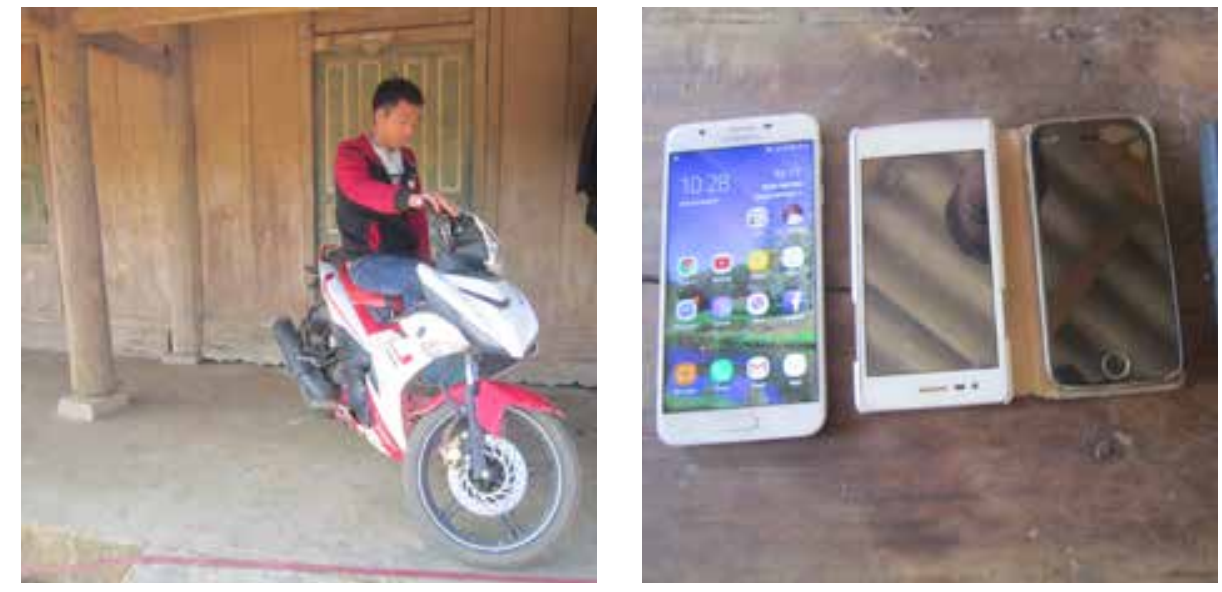

A motorbike is important because it is very convenient to travel and can be used to carry goods.

The phone is important because it is veryconvenient for communicating and entertainment. 


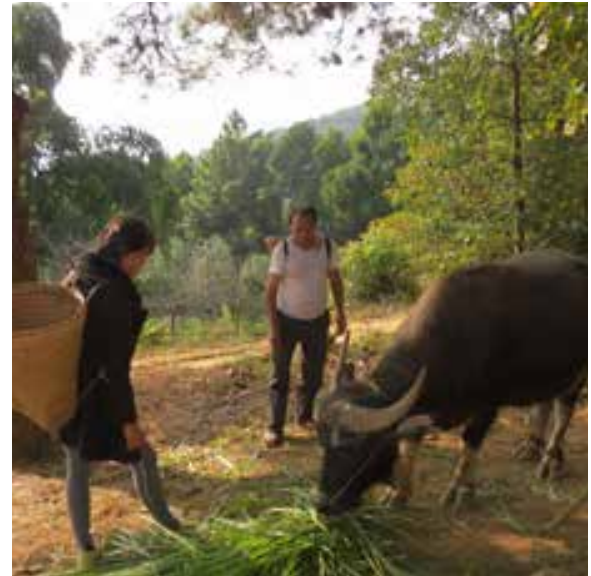

The buffalo is an important asset because it is used for cultivation (ploughing) and it is valuable.

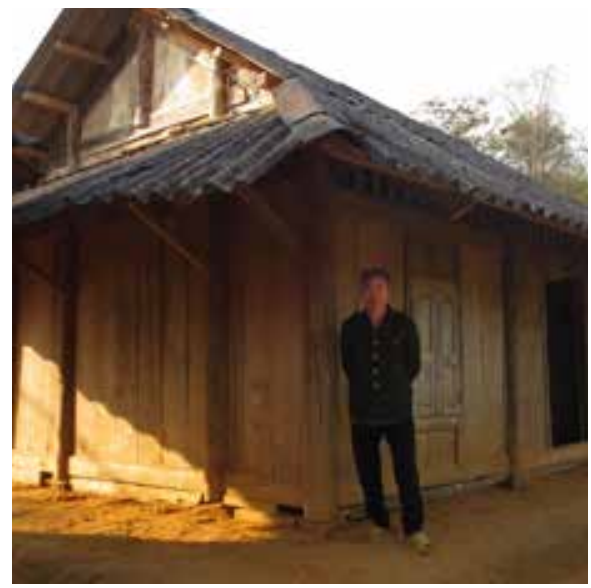

The house is the most important thing with Mong's family.

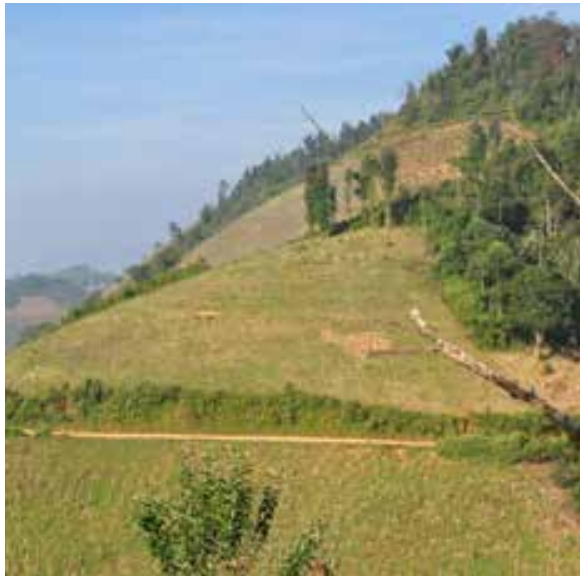

Land is a very important asset of the Hmong family because It brings products and cash for farmers through cultivation.

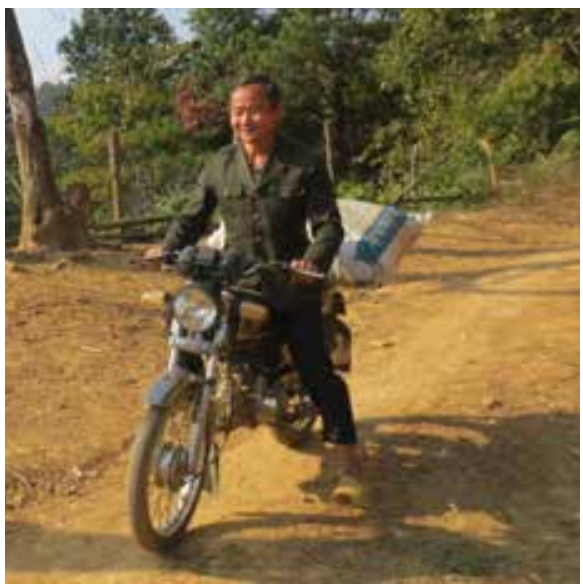

A motorbike is an important asset for travelling and transporting agricultural products.

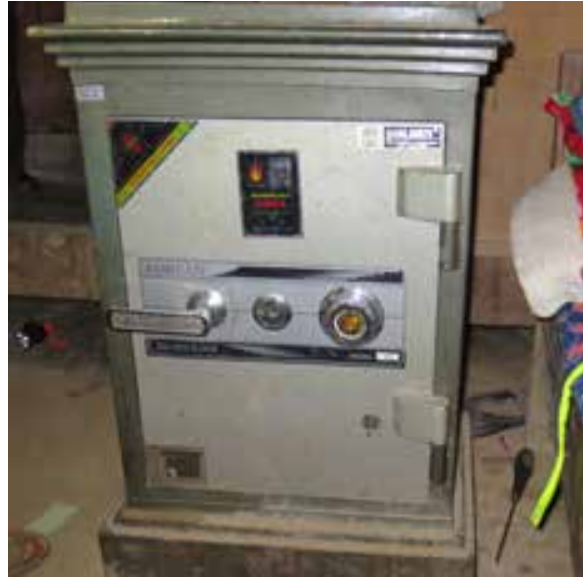

Farmers usually keep money and valuable assets in the safe.

\section{Younger Hmong women}

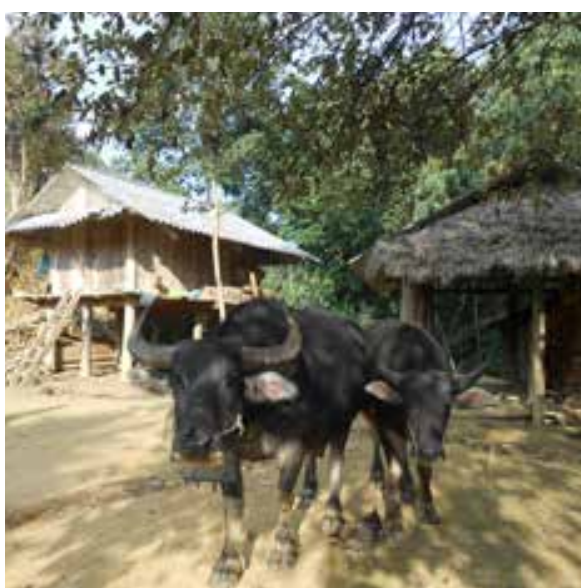

A young farmer said she could not do prepare the land without this ${ }_{46}$ buffalo.
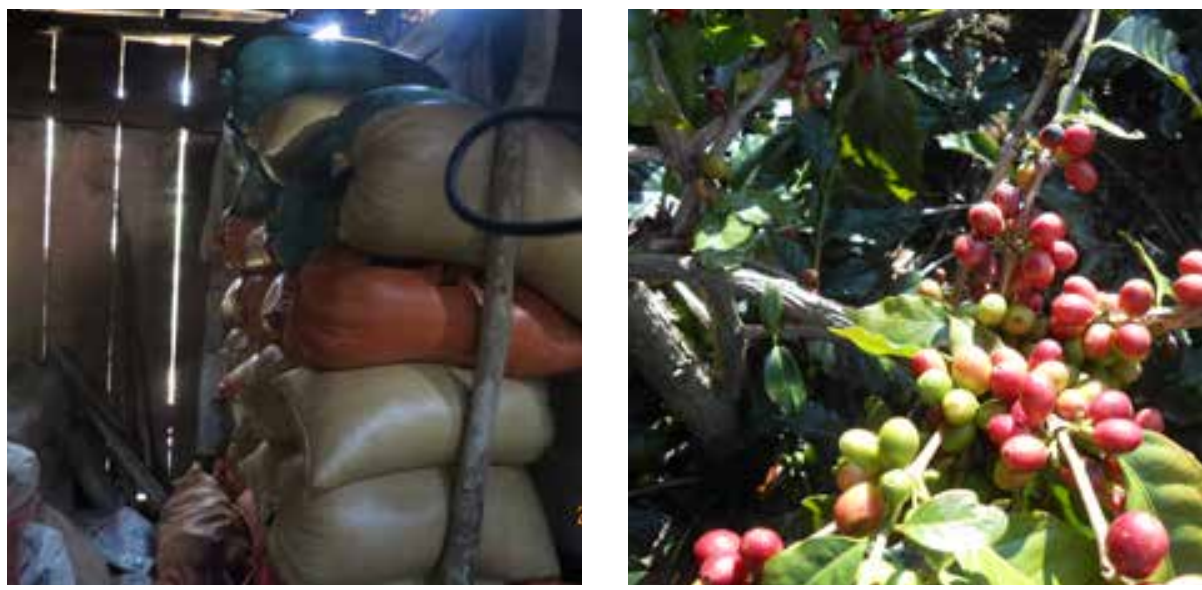

Rice and grain are very important. Good and fresh coffee seeds are very valuable to farmers. 


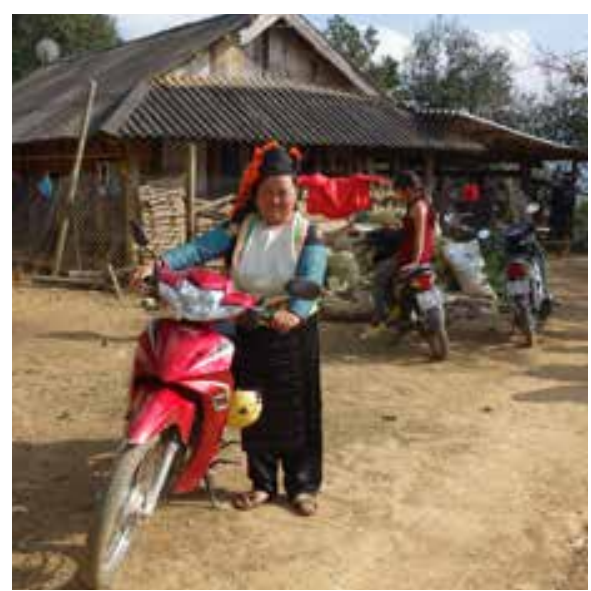

A motorbike is the most important thing for May.

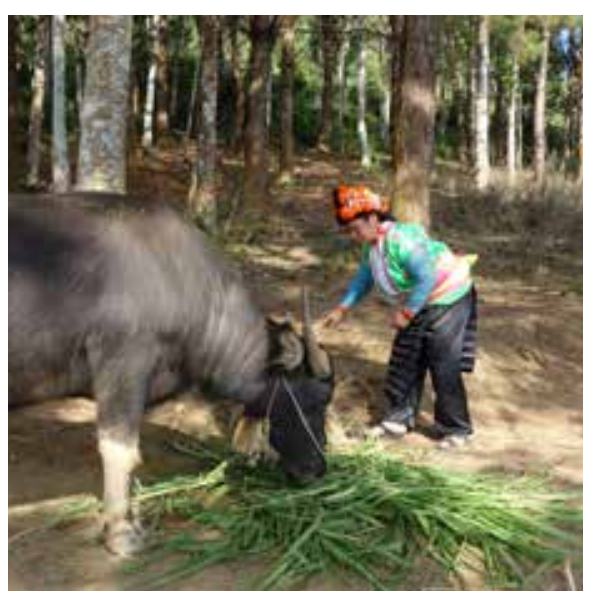

A buffalo is the most important thing because she can't do ploughing.

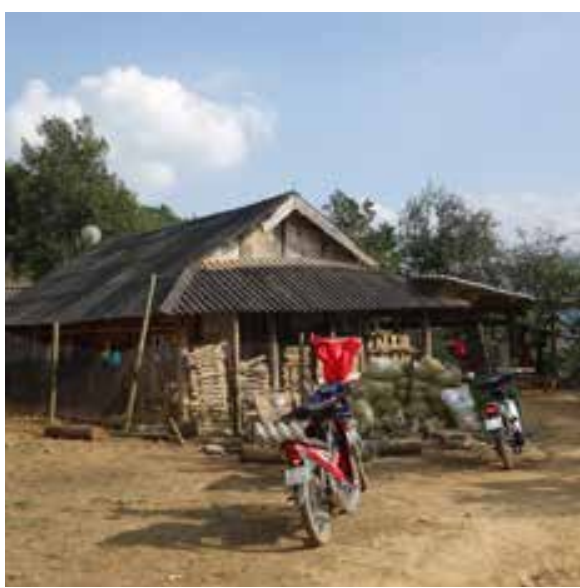

The house is the most important thing for Thao because it is where she lives with her family.

\section{THAI GROUP}

\section{Younger Thai men}
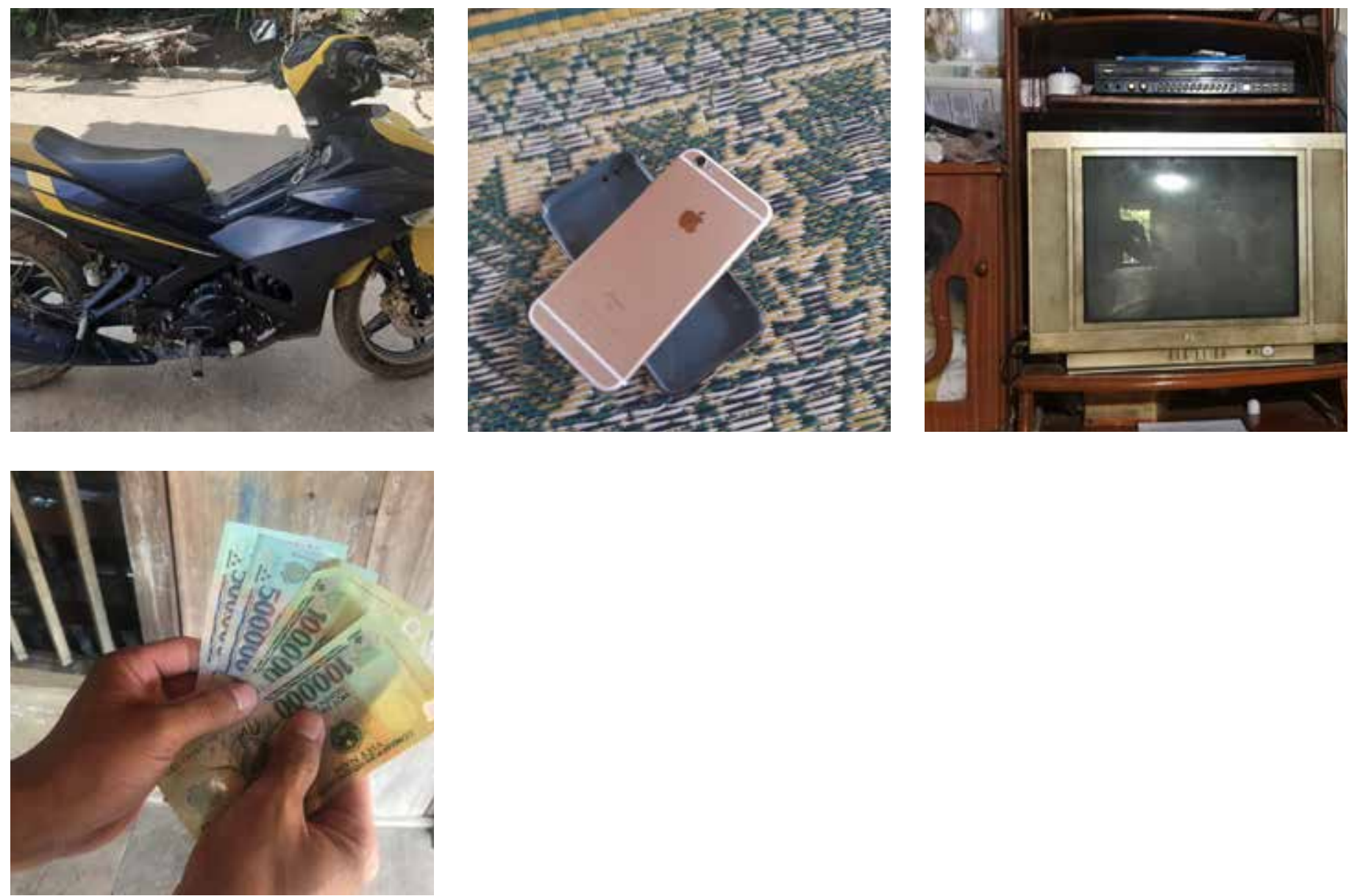

Motorbike, mobile phone, television and money are the most important things. 

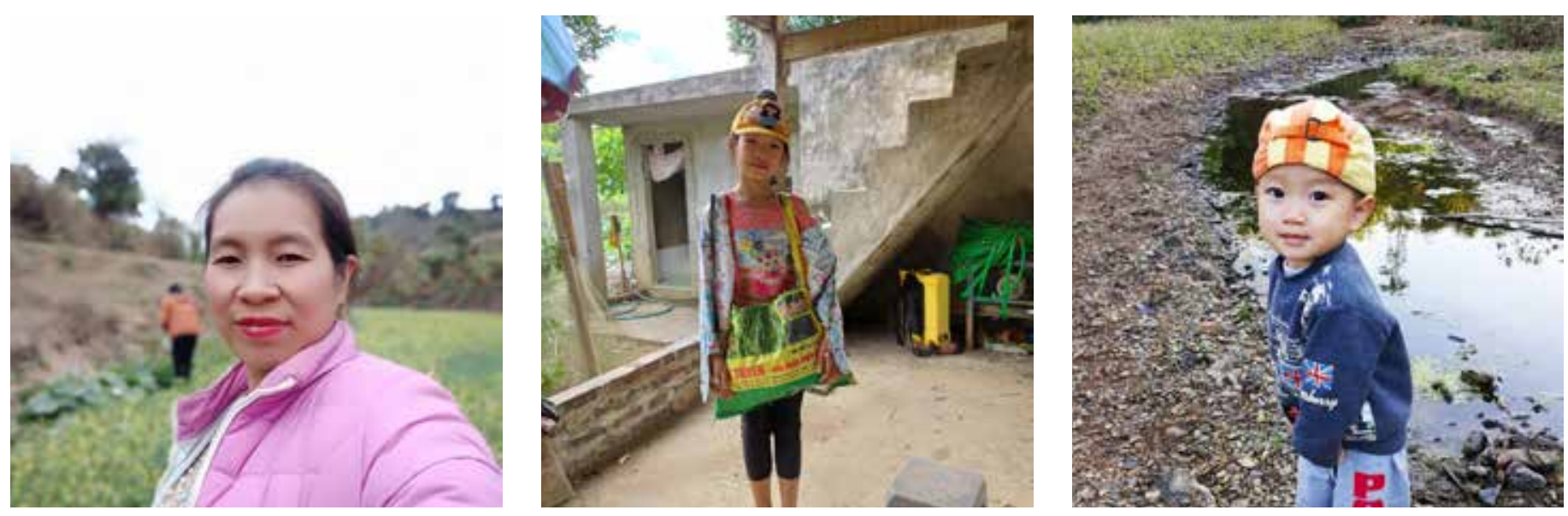

Wives and children are the most important people.

\section{Younger Thai women}
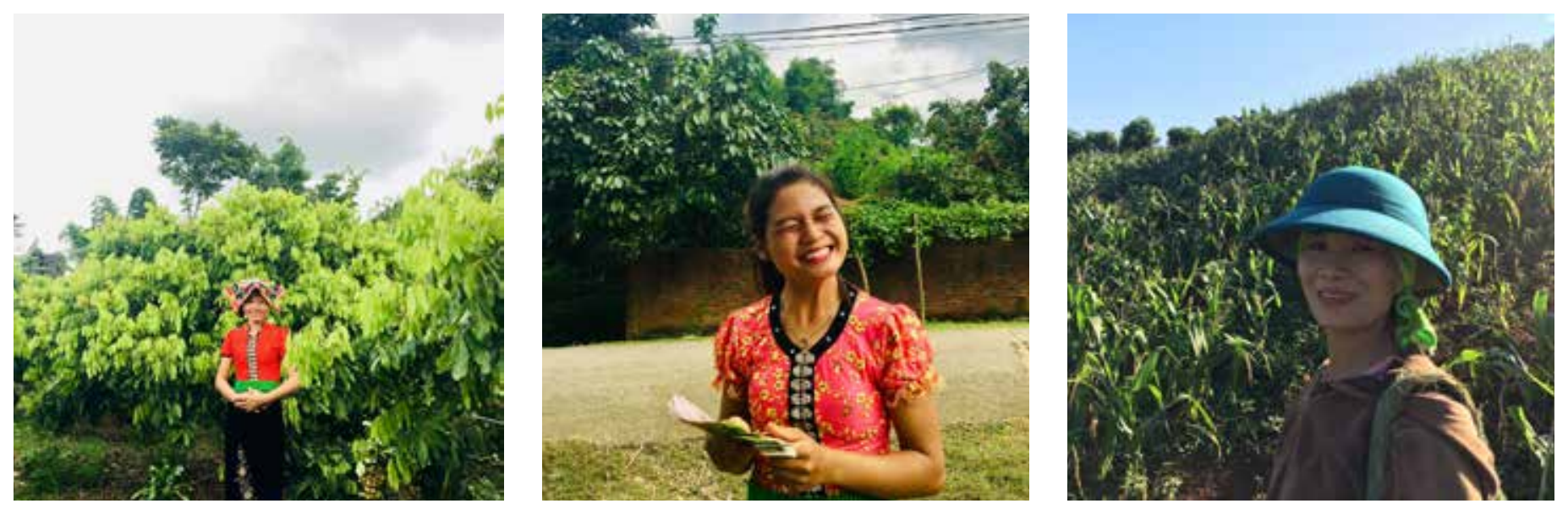

I love myself the most.

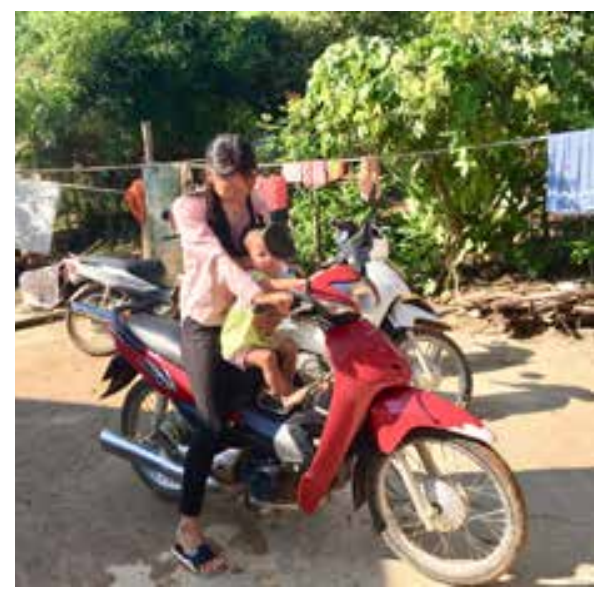

My child is the most important person. 


\section{Older Thai women}

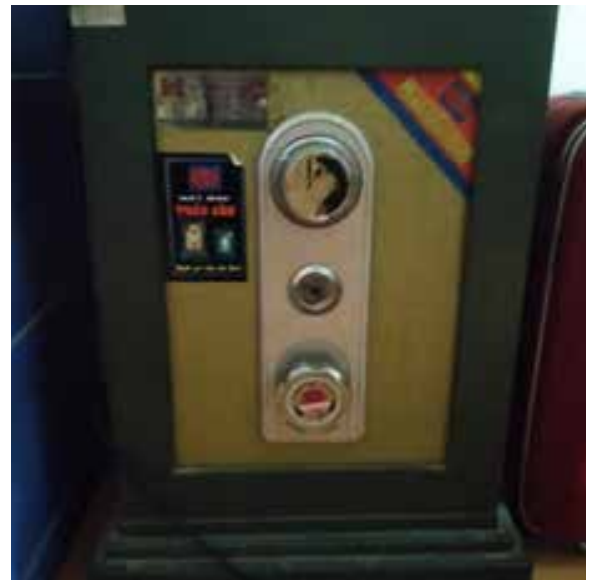

Money safety box.

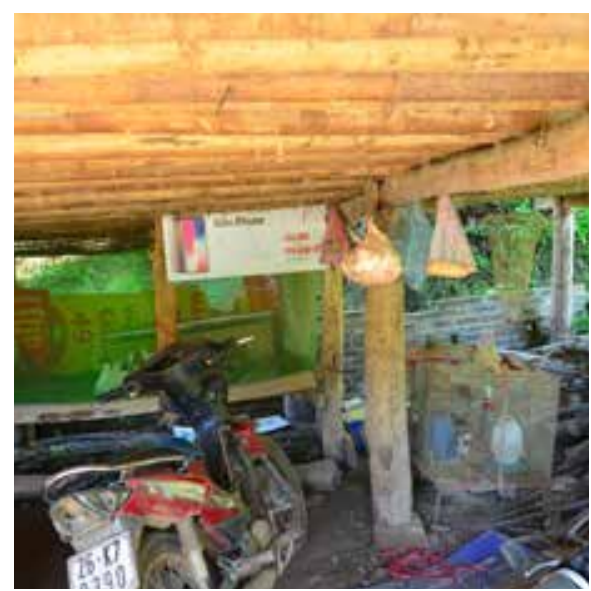

My motorbike is the most important thing as it helps me transport agricultural products and inputs to and from the fields.
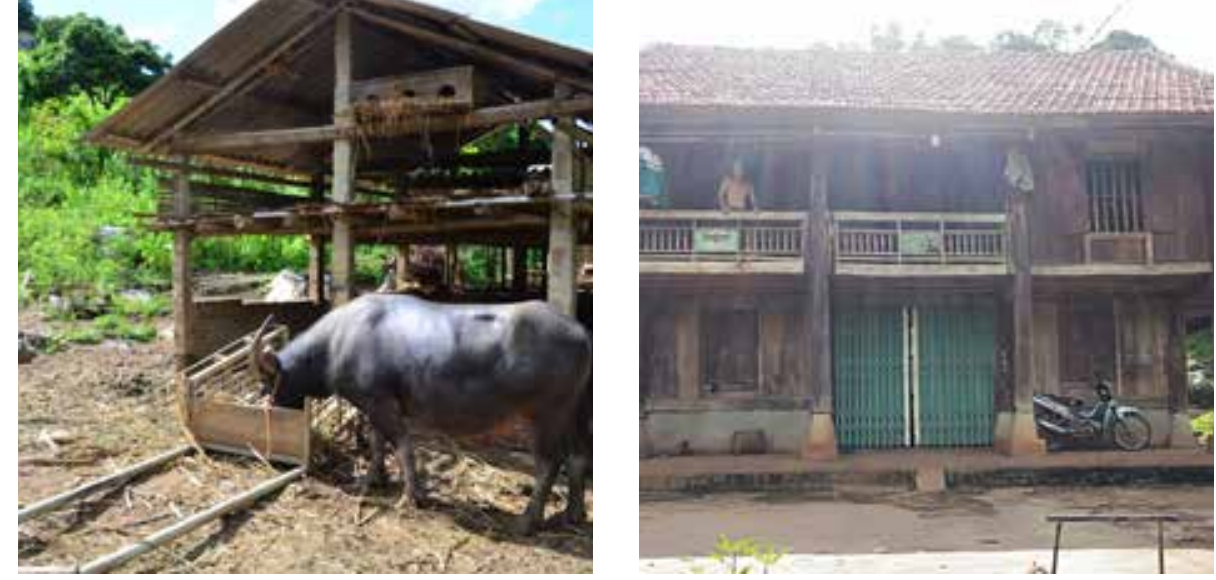

Buffalo is the most important I love my house the most. thing. 
Question 3: To whom/from what material do you learn new things/technologies and why? (material, persons/innovators)?

\section{HMONG GROUP}

\section{Younger Hmong men}

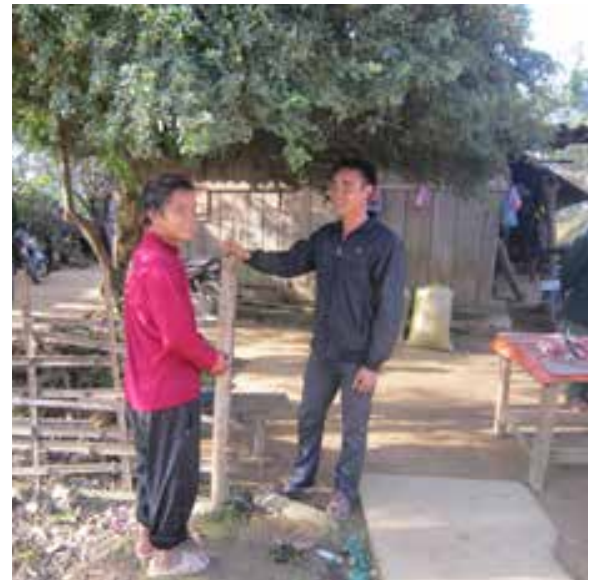

Learning new knowledge and techniques from neighbours.

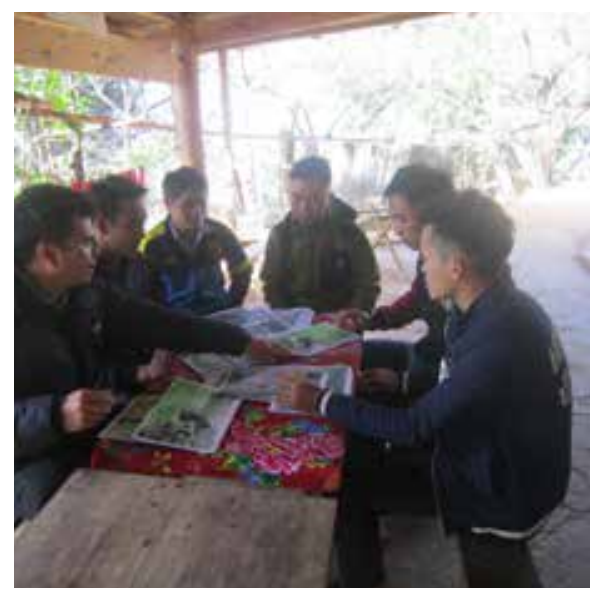

Learning new knowledge and techniques through training and meetings.

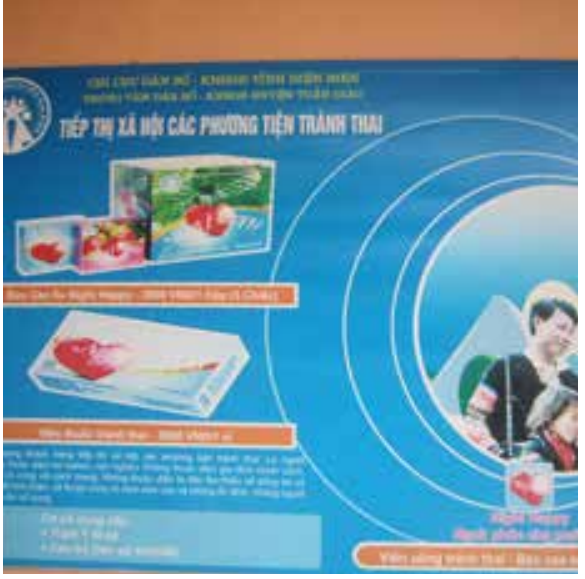

Learning new knowledge and techniques from the poster because it is easy to understand.

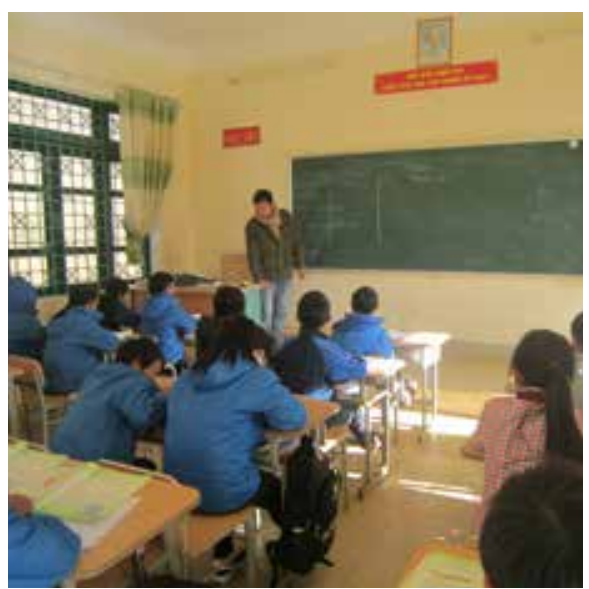

Learning new knowledge and techniques from the teacher who can provide techniques.

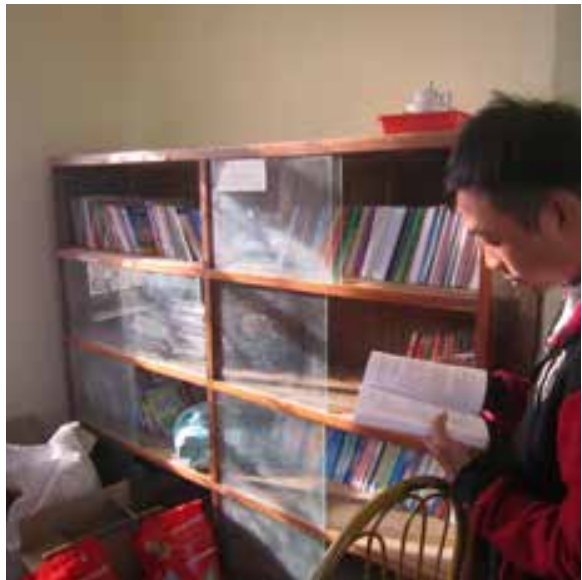

Learning new knowledge and techniques from books and training material.

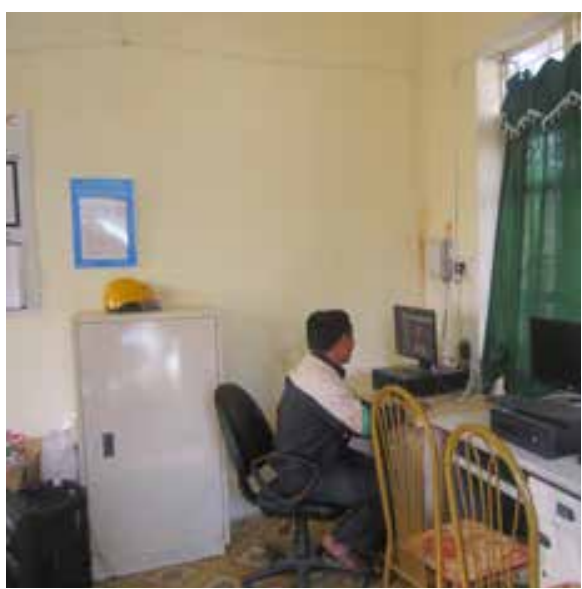

Learning new knowledge and techniques through the internet. 


\section{Older Hmong men}

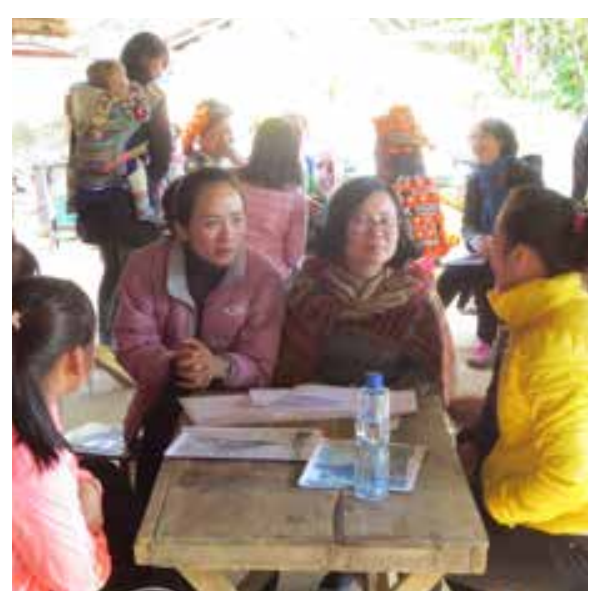

A training course about raising livestock for farmers.

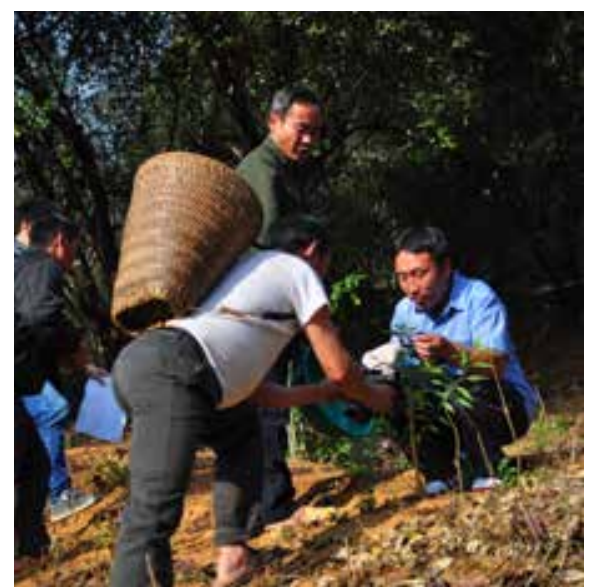

Discussing and learning from neighbours.

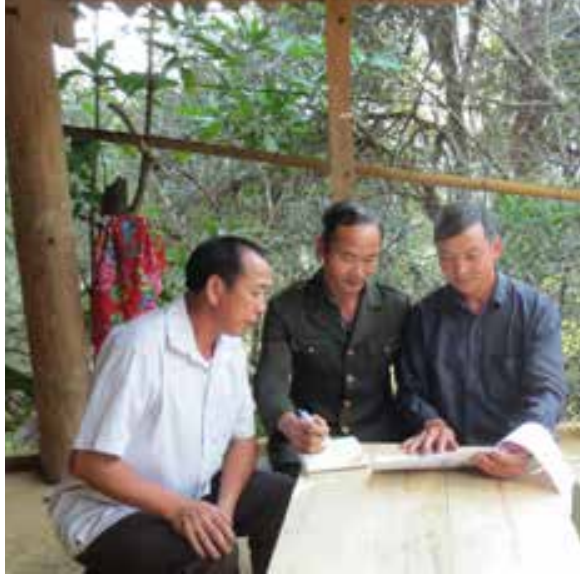

Farmers reading guidelines.

technical

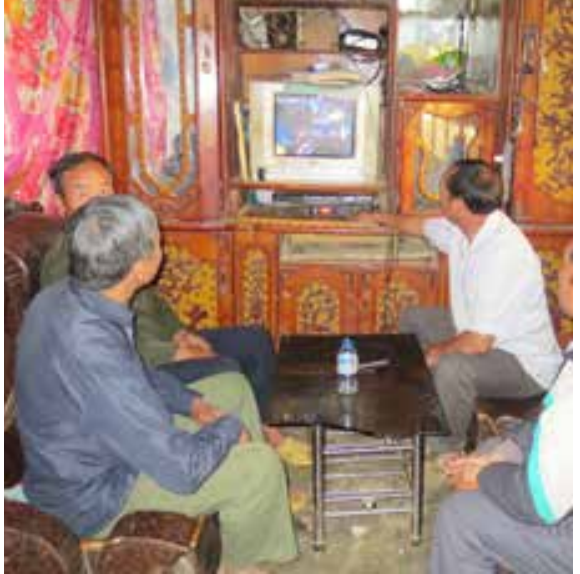

$T V$ is an information source for Hmong farmers.

\section{Younger Hmong women}

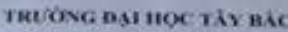

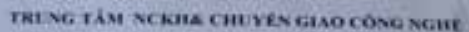

\section{TẢI LIỆU TẬP HUẤN}

THUẠT GÂY TRÒNG CHĀM SÓC SC

A training material indicating that a female farmer has learnt techniques and methods of tree management. 


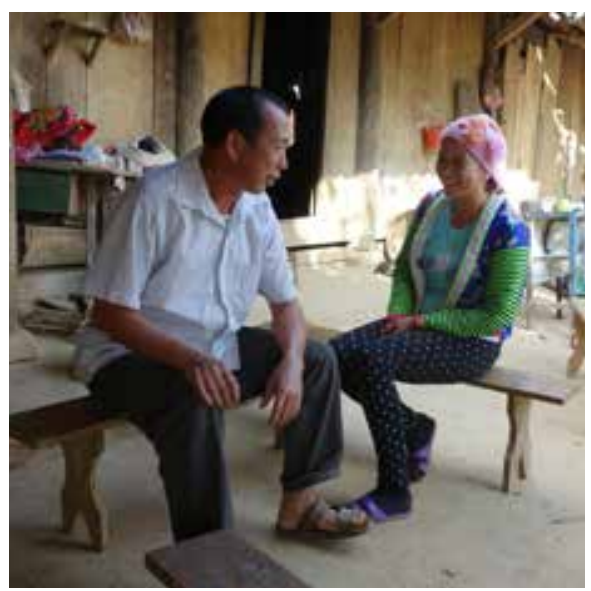

The village head is the source of information.

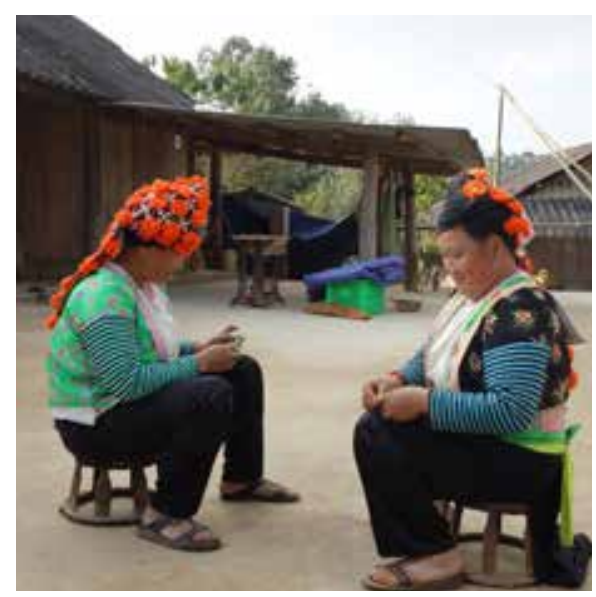

Cuc - Huong's neighbour - is the source of information about coffee planting and management.

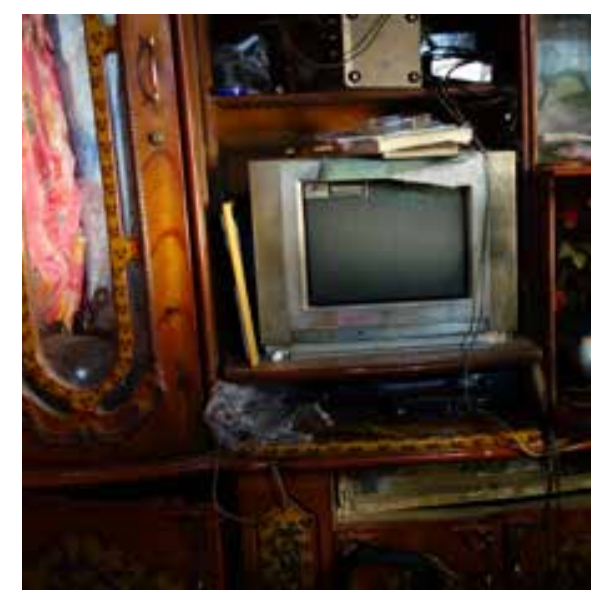

VT16 and VTV5 on television are the sources of information.

\section{THAI GROUP}

\section{Younger Thai men}

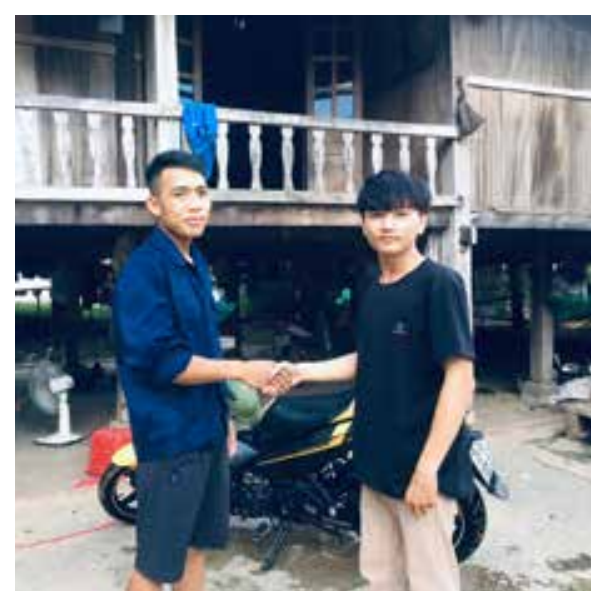

My friends.

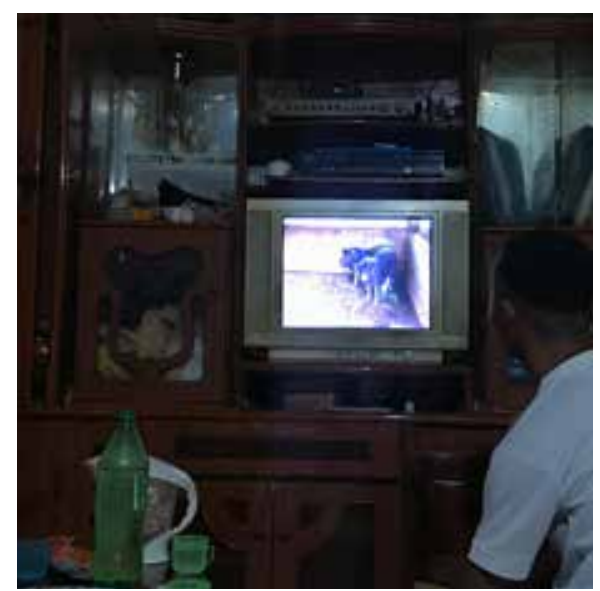

Television and mobile phone.

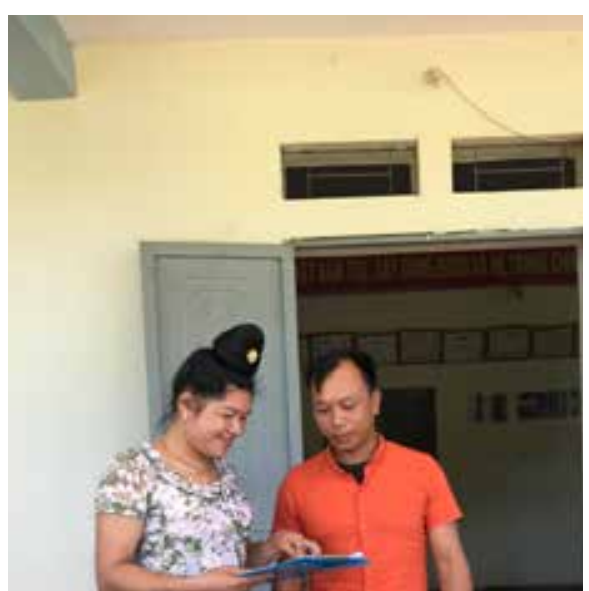

Extension worker.

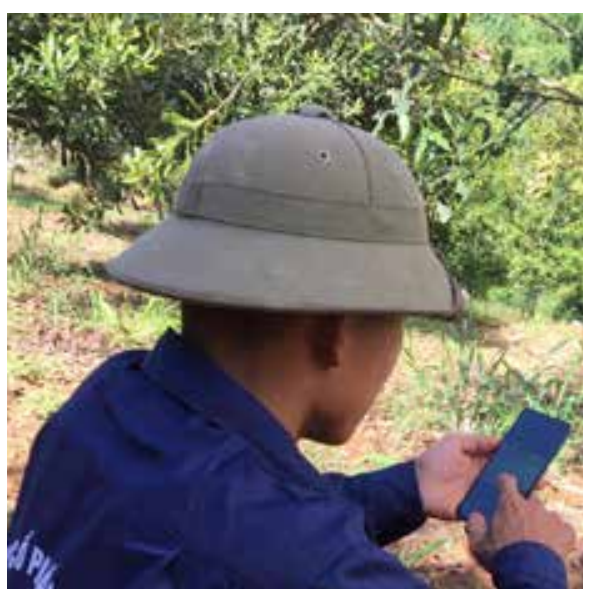

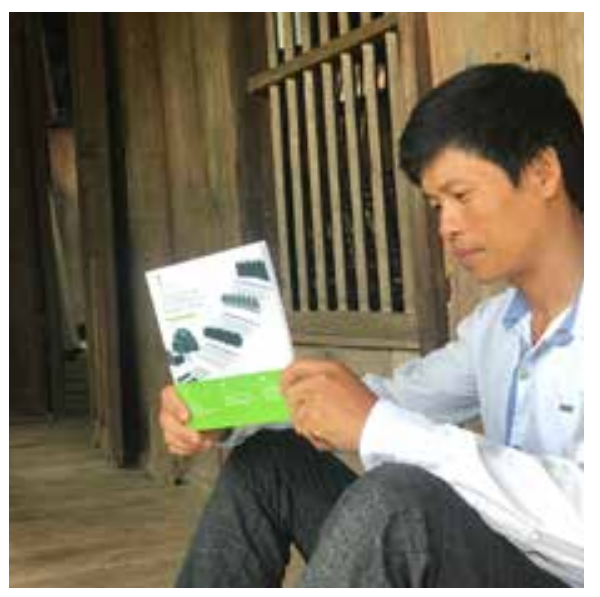

Training material (from project). 


\section{Older Thai men}

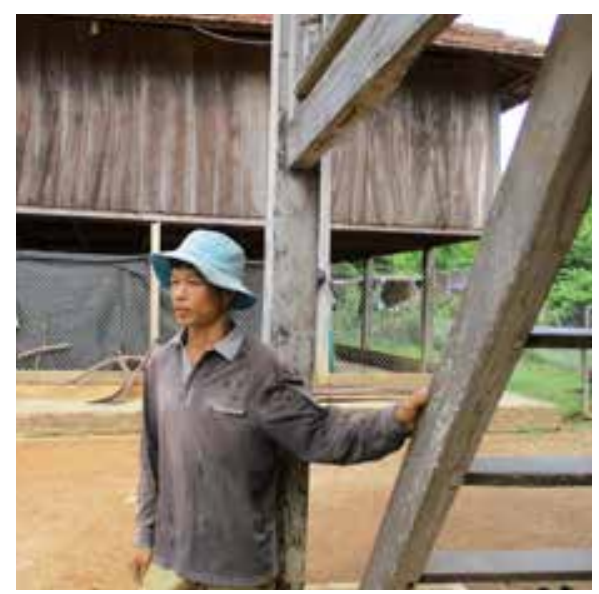

My neighbour.

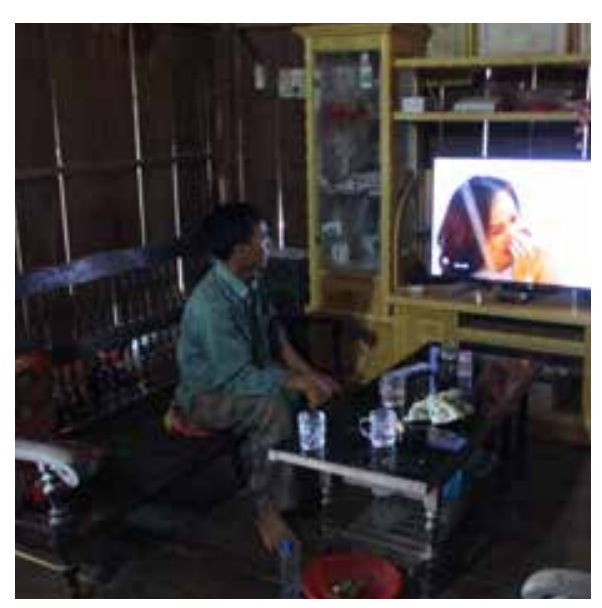

Television.

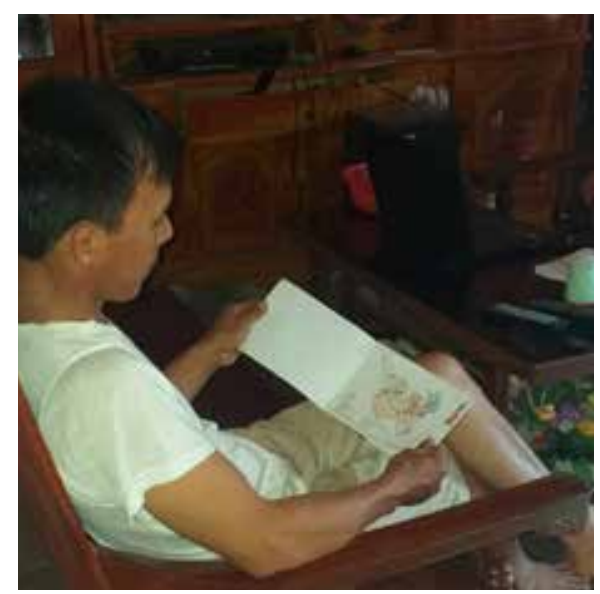

Training material.

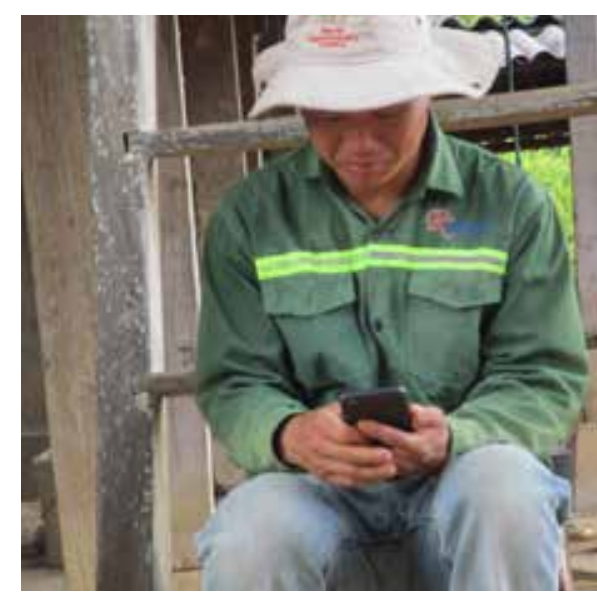

Mobile phone.

Television.

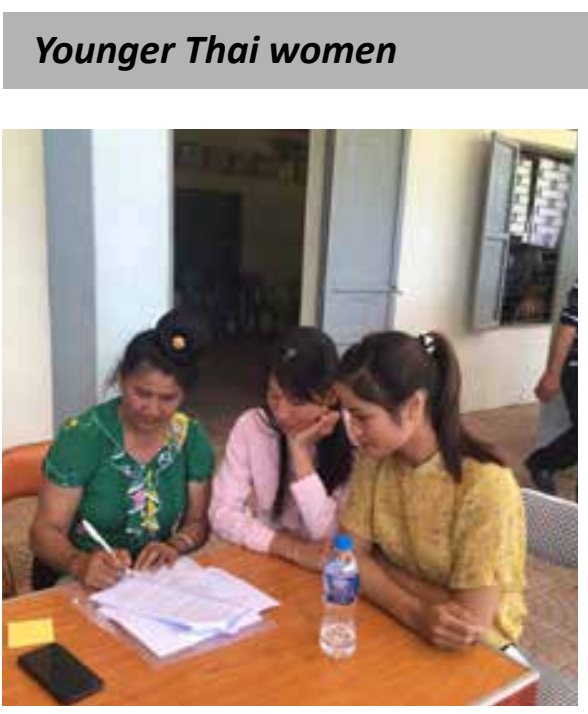

Friends and neighbours.

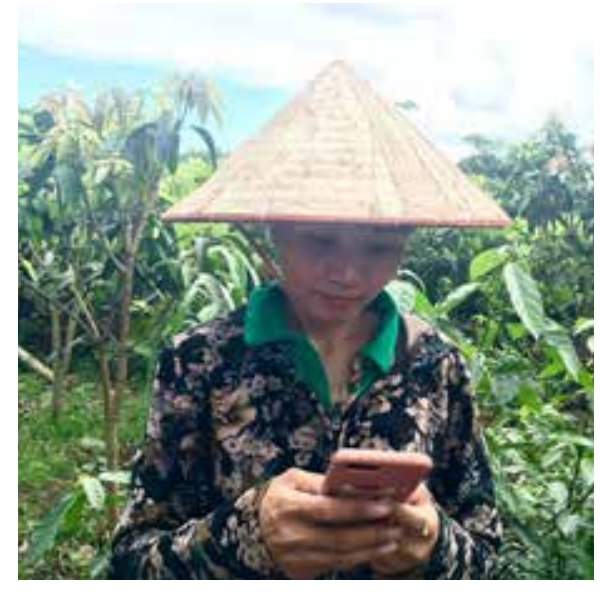

Mobile phone (through internet).

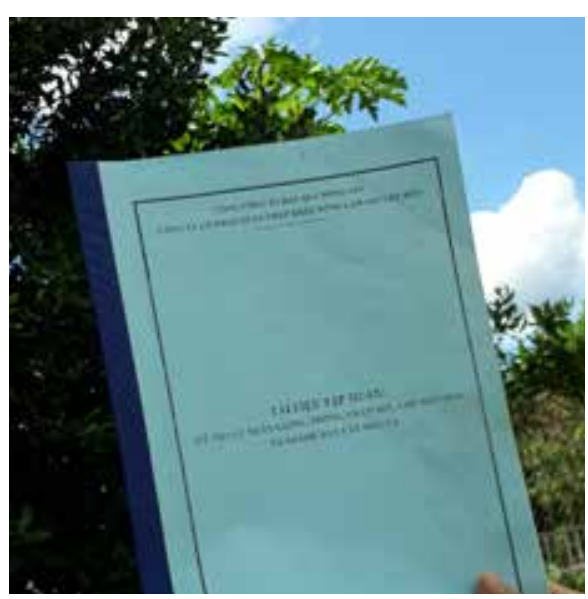

Extension material. 


\section{Older Thai women}

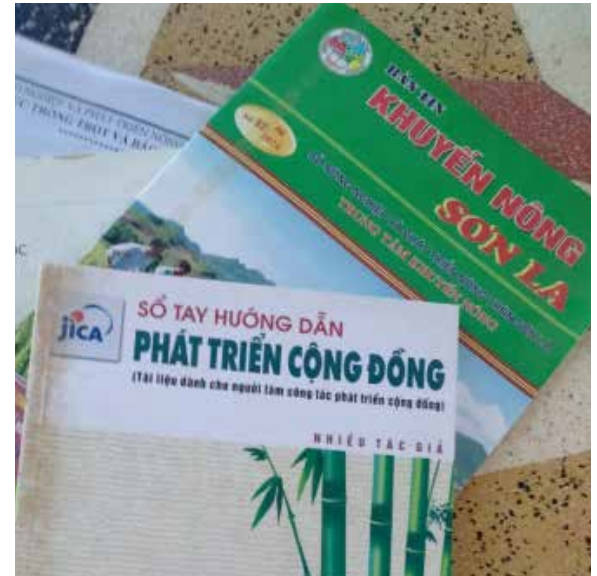

Extension material and extension workers.

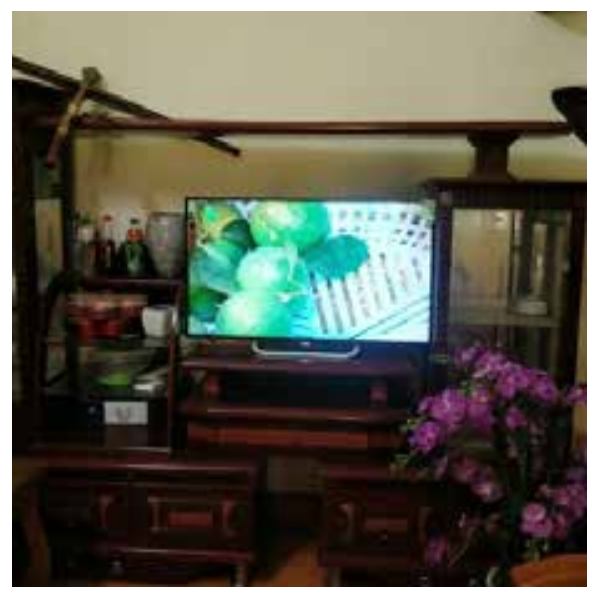

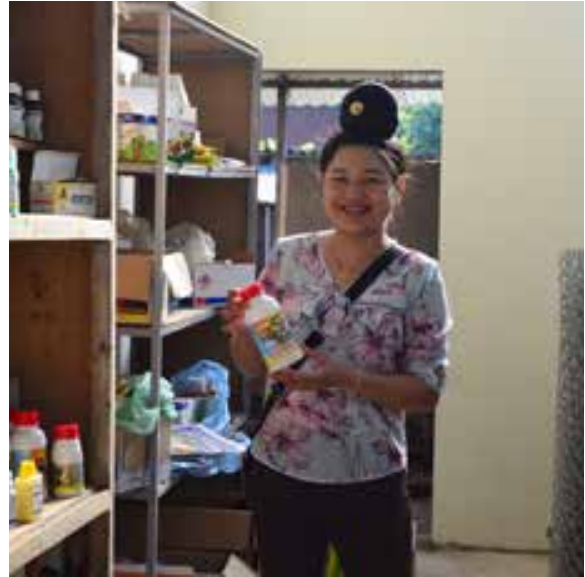

Agri-input shop.

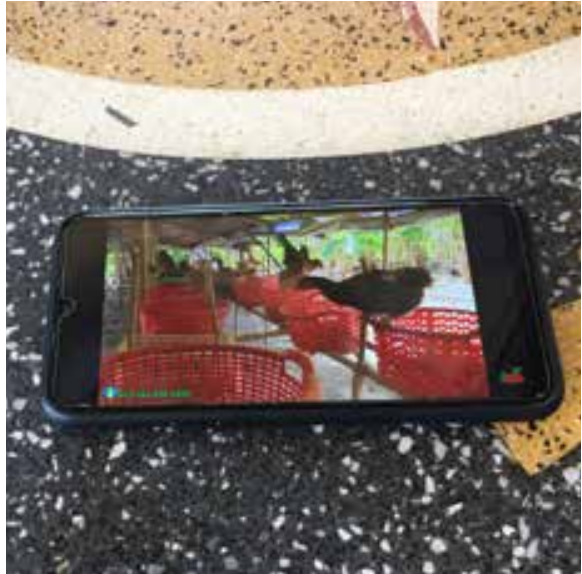

Mobile phone.

Television.

Question 4: What are the challenges in farming and why?

\section{HMONG GROUP}

\section{Younger Hmong men}

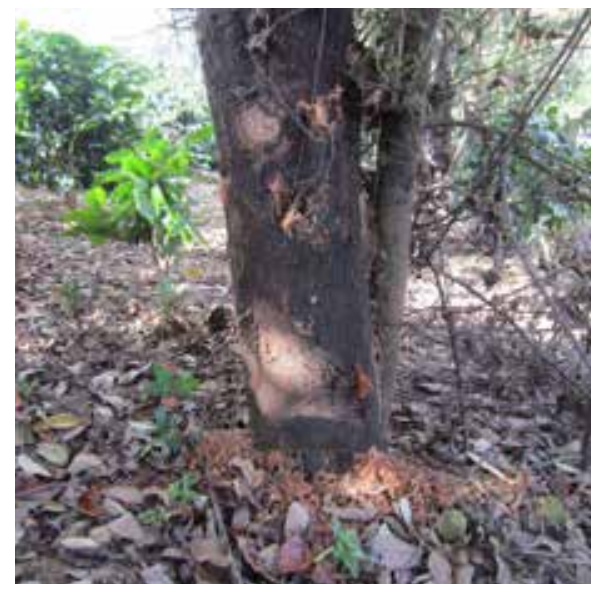

Stem borer affects son tra: stem, Lack of money. branches and fruit. It affects the growth of trees and reduces yields.

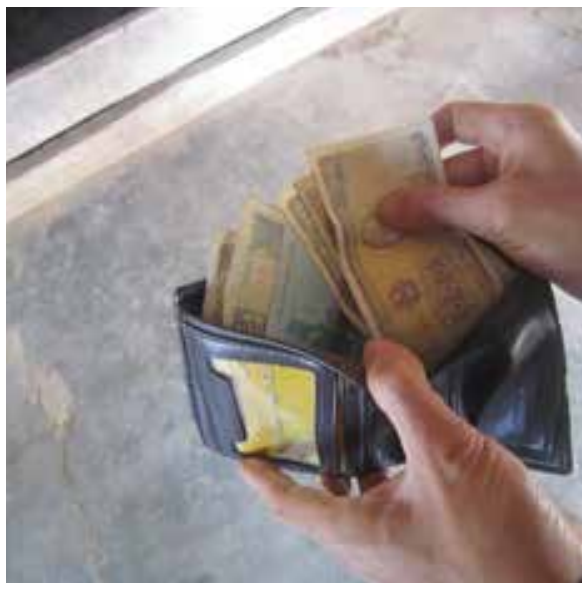

Landside/erosion: affect trees and crops, destroy fields and roads. 


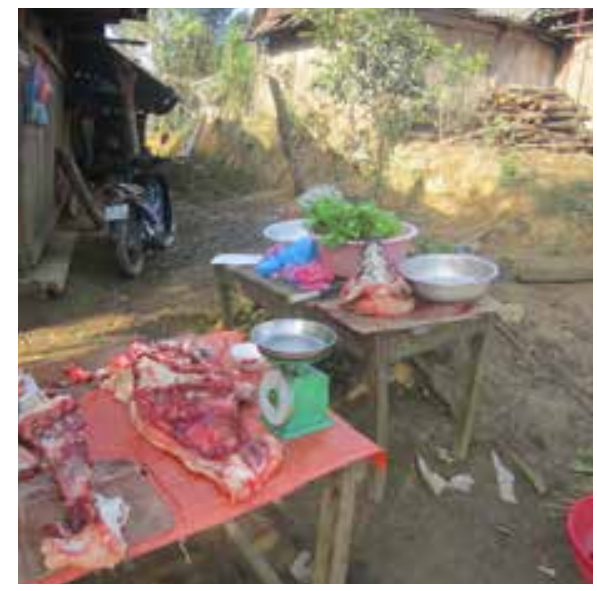

Low sale price of products: because almost all products are retail and market price is fluctuating.

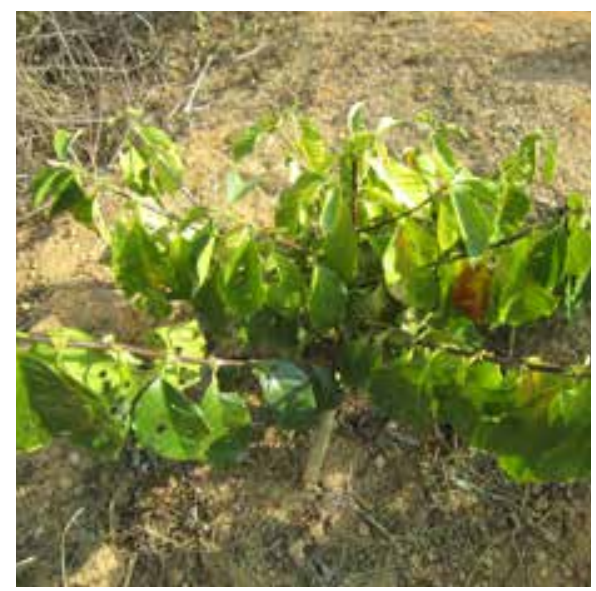

Diseases affect coffee: yellow leaves, they affect the growth of trees and reduce yields.

\section{Older Hmong men}

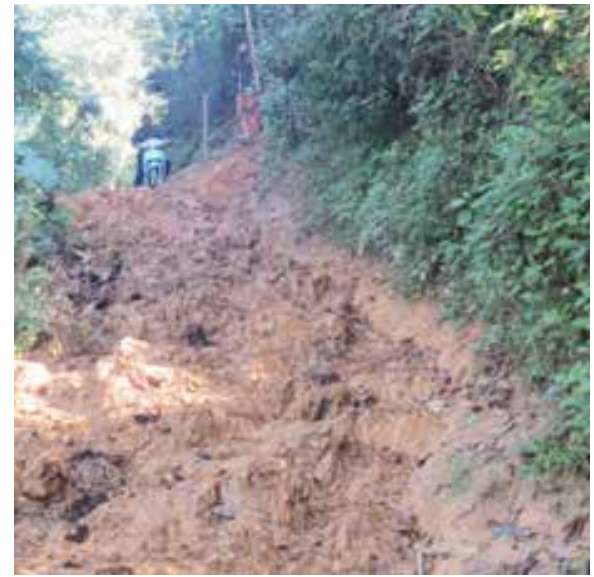

Bad road.

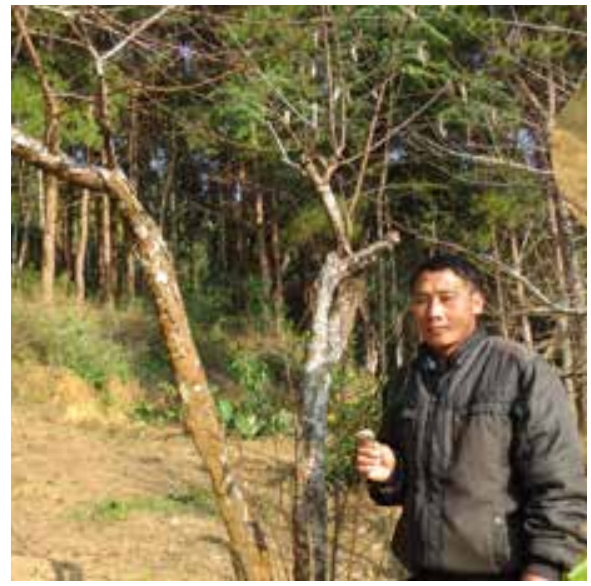

Pest-affected peach reduced fruit yield.

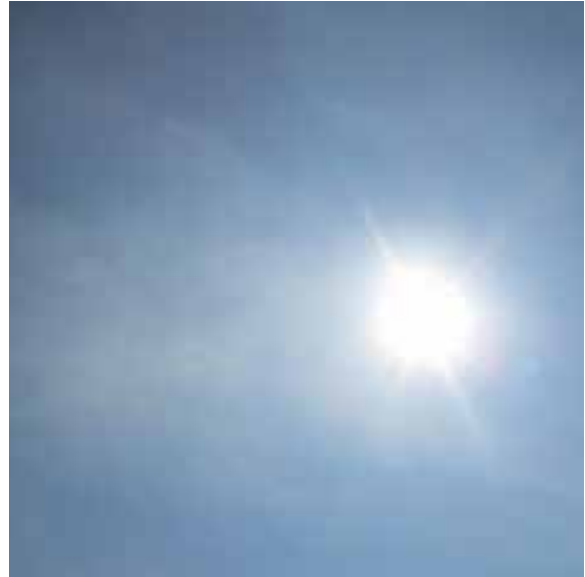

The prolonged drought resulted in a lack of water.

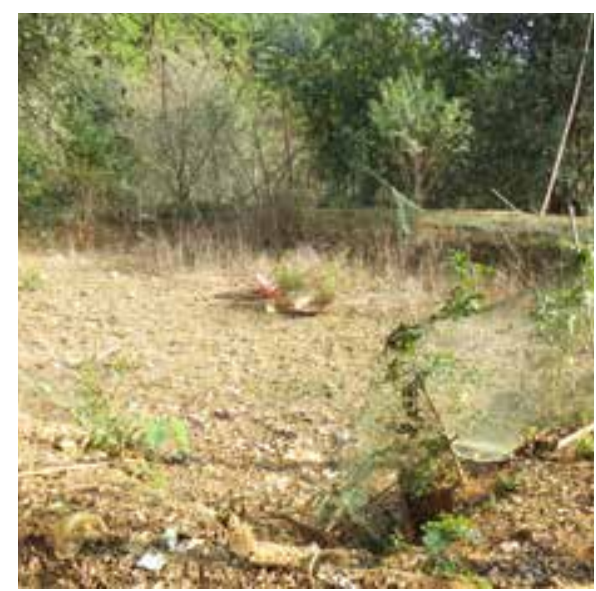

tree and Lack of irrigation water.

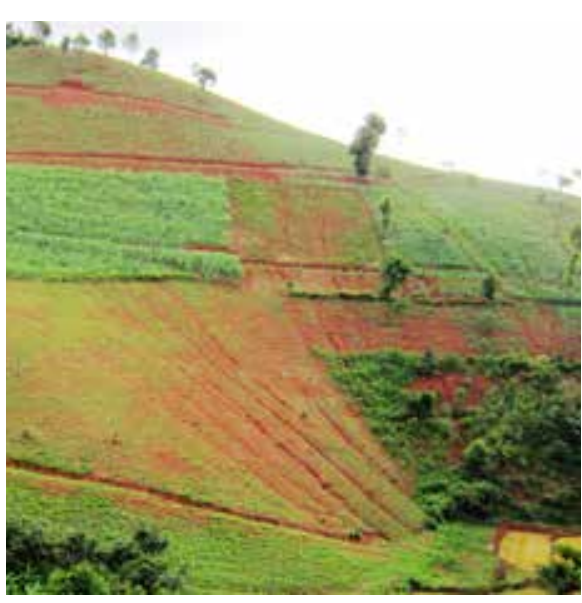

The steep slope causes soil erosion and difficulty of cultivation. 


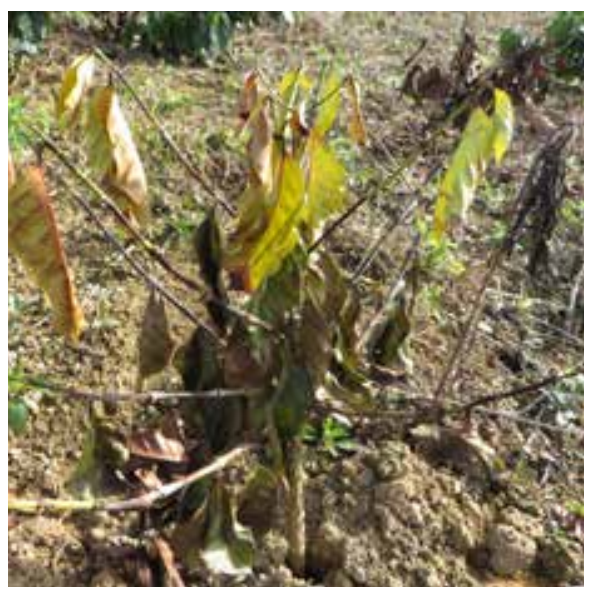

Coffee is destroyed by stem borer.

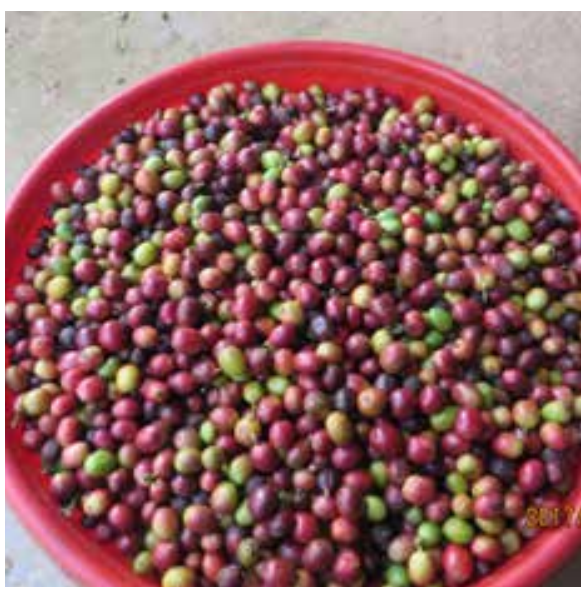

Fluctuating coffee price is always a concern to farmers.

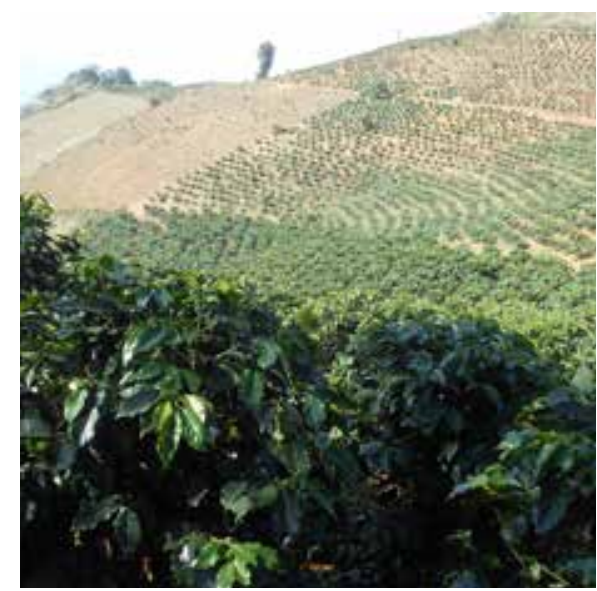

Sloping land is a challenge for farmers in agricultural cultivation.

\section{Older Hmong women}

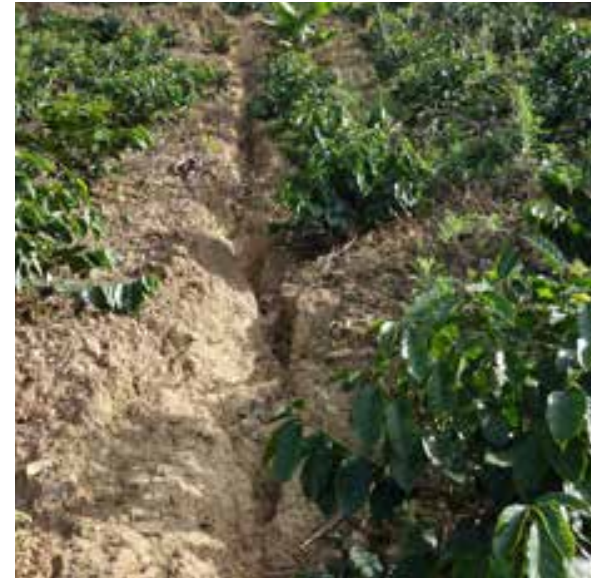

Soil erosion forms small channels (or gullies) in the coffee plot.

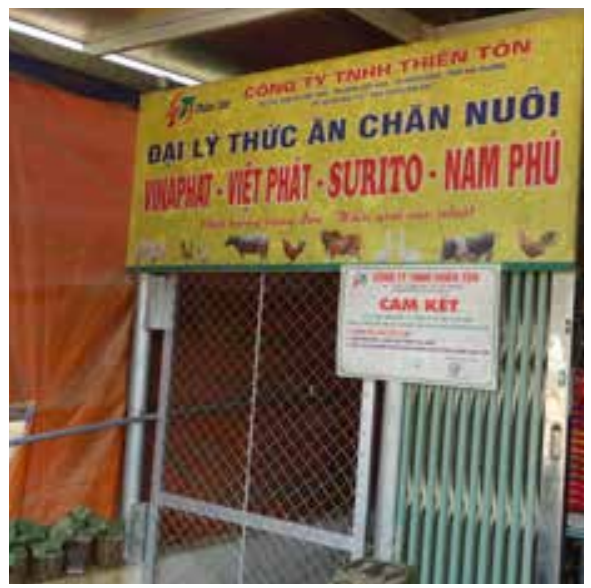

Lack of money to buy fertilizer.

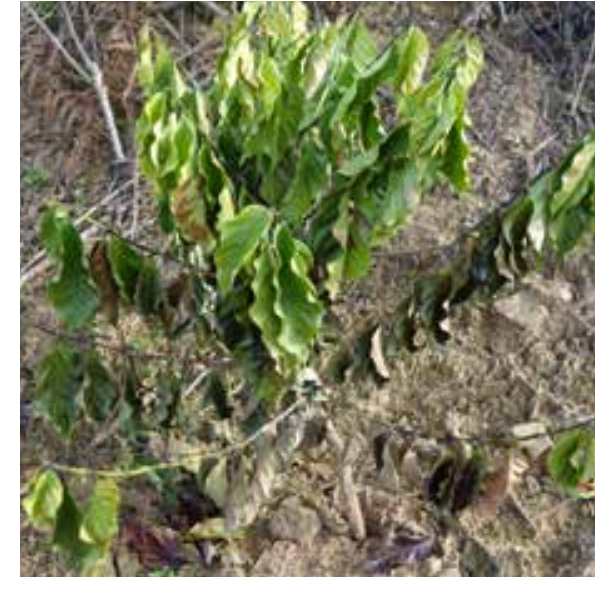

Disease on coffee: coffee leaves dry and then tree dies.

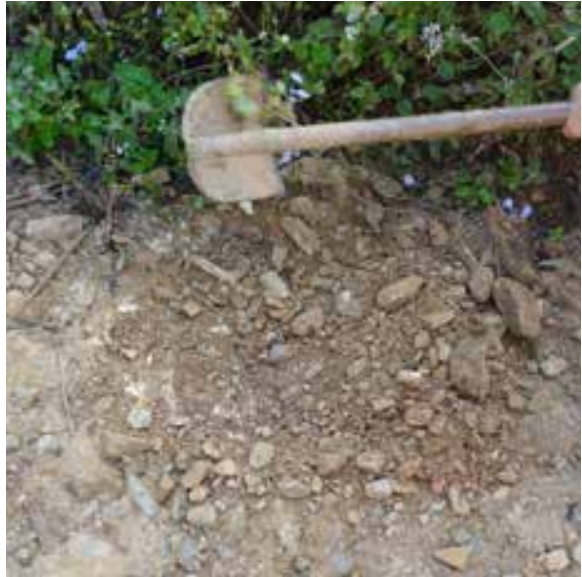

Digging holes for planting coffee requires lots of labour. 
THAI GROUP

\section{Younger Thai men}

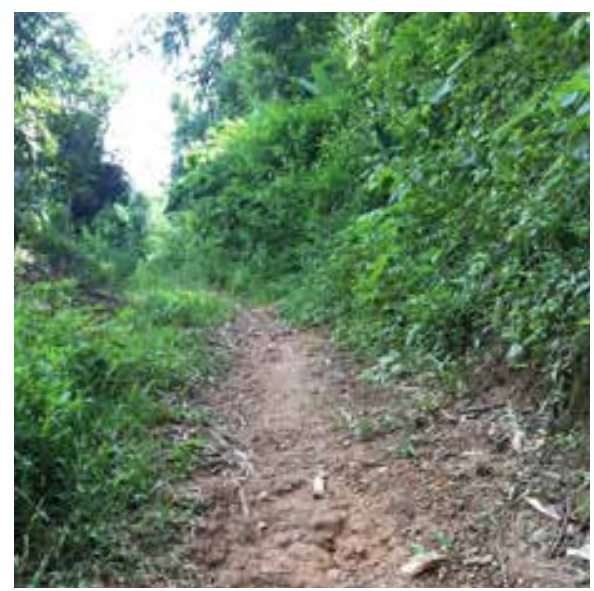

Bad road.

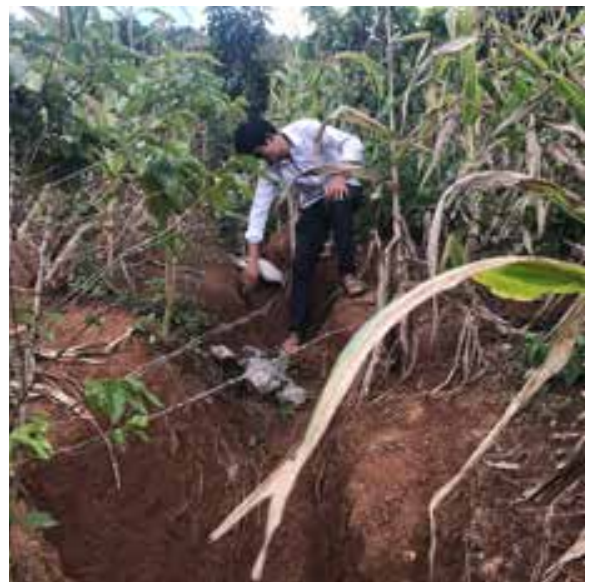

Soil erosion.

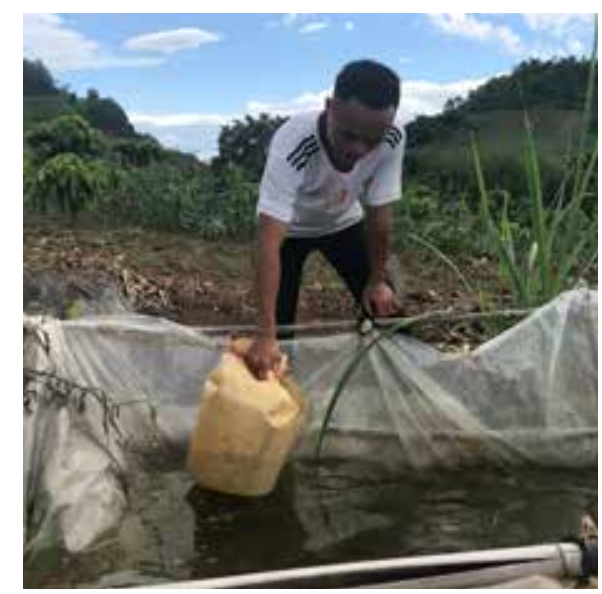

Lack of water.

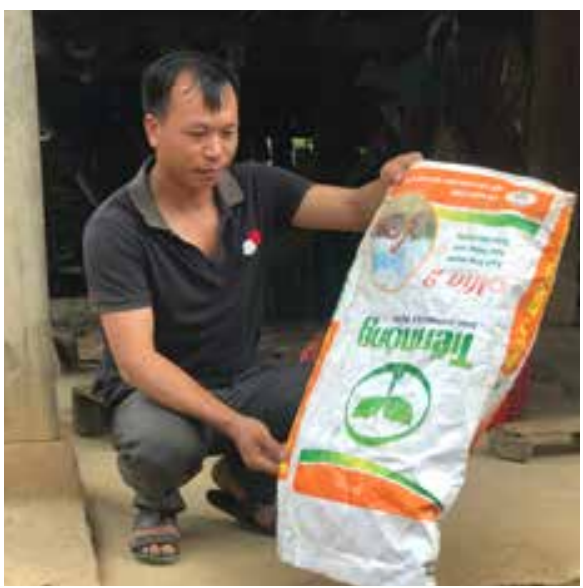

Lack of fertilizer.

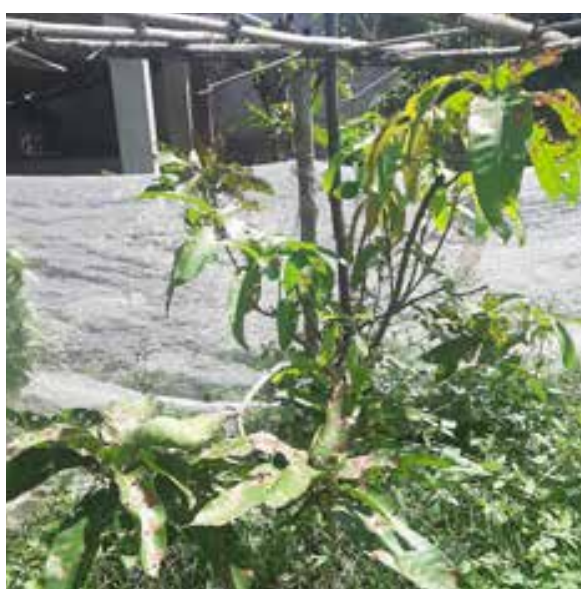

Pests and diseases.

\section{Older Thai men}

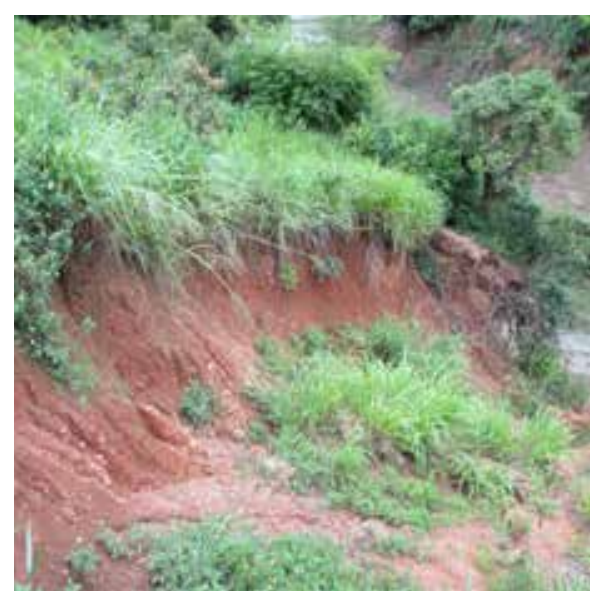

Soil erosion.

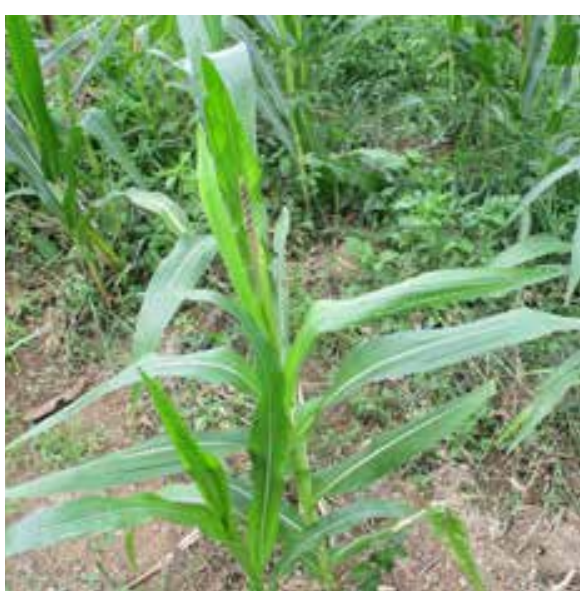

Drought impact on maize.

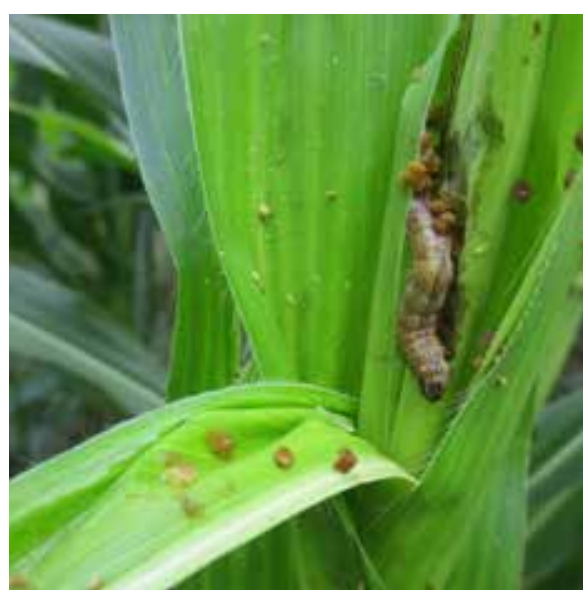

Maize pests. 


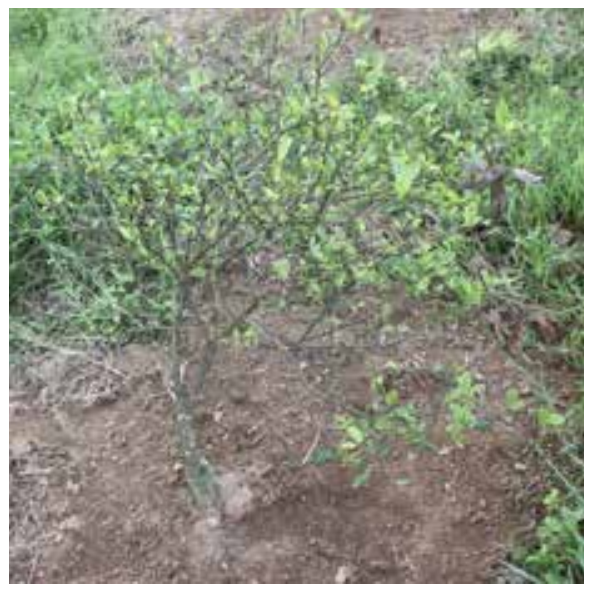

Poor soil.

\section{Younger Thai women}

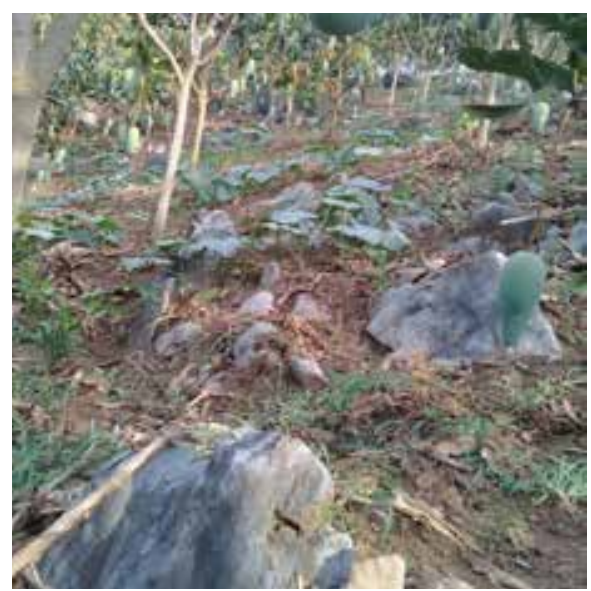

Soil with lots of rock.

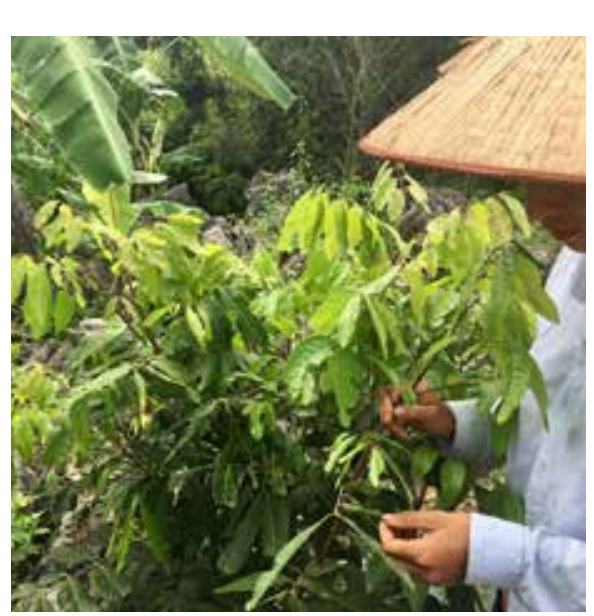

Fruit-tree pests and diseases.

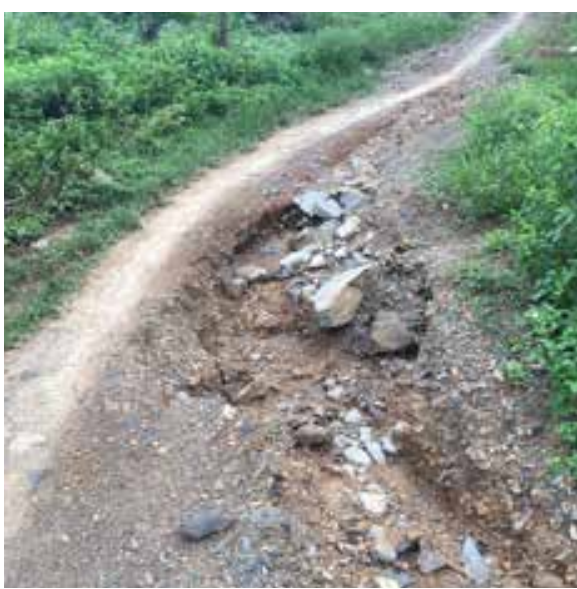

Bad road in the village.

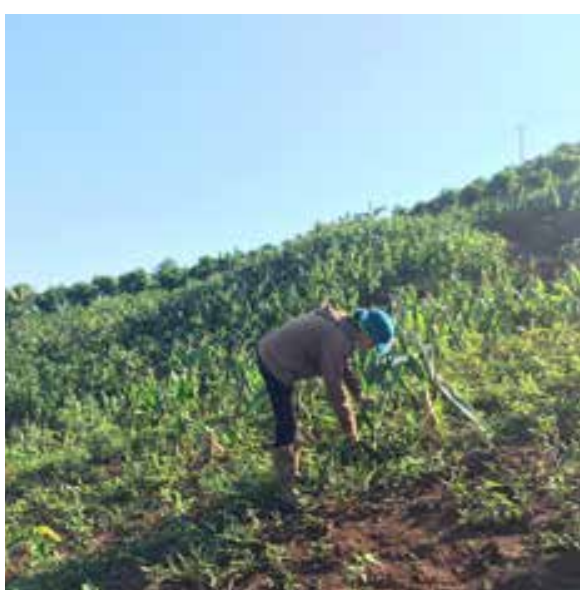

Steep slope in the field. 


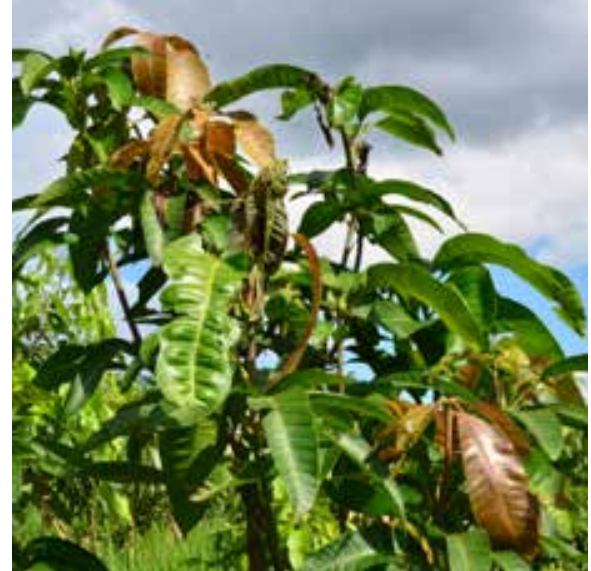

Mango pest.

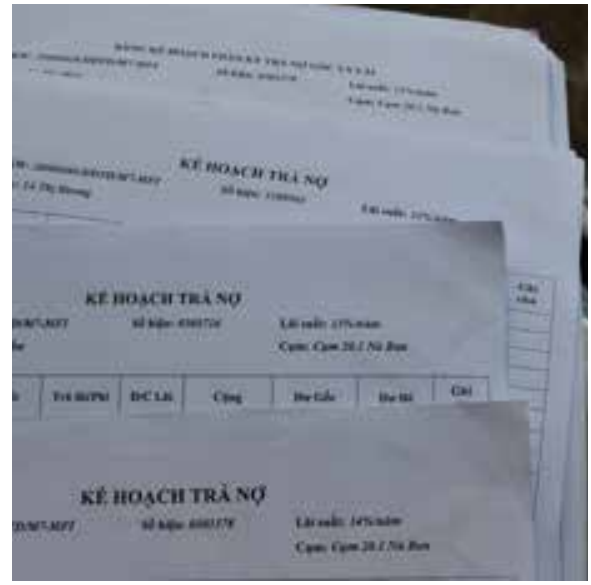

Loan from private credit.

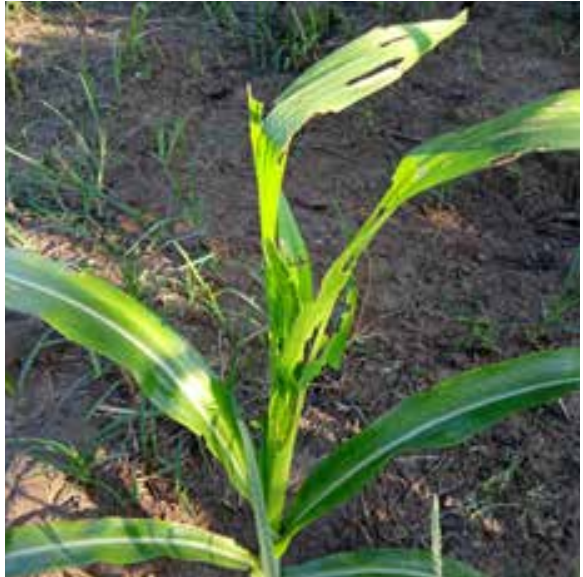

Maize pest.

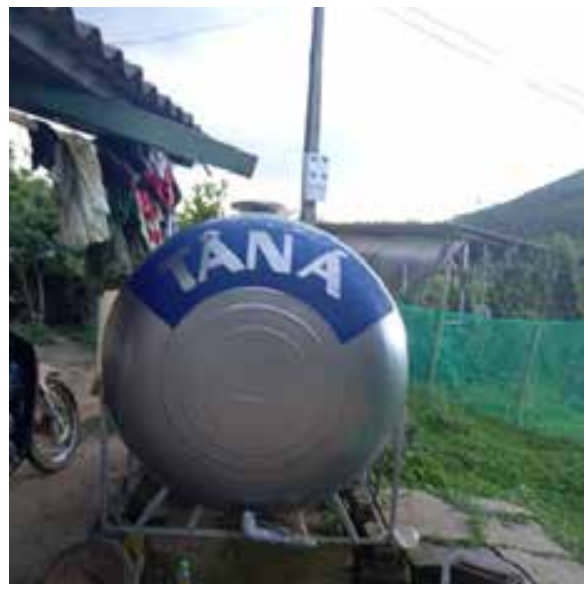

Lack of water, cement tank.

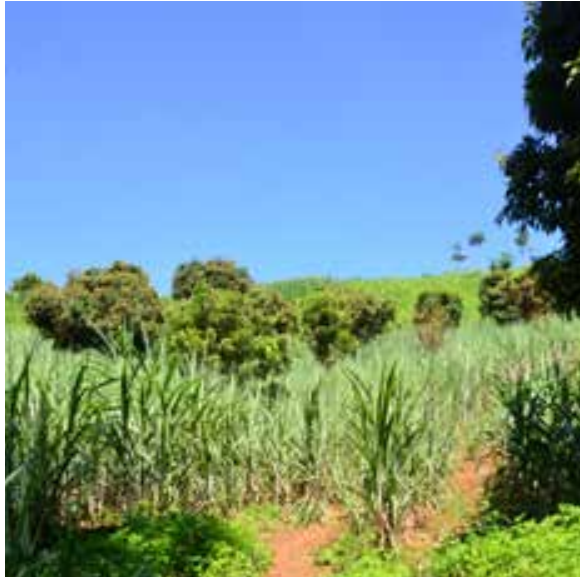

Bad road in the field, cannot travel by motorbike in the rain.

Question 5: What is your wish to improve the cultivating system?

\section{HMONG GROUP}

\section{Younger Hmong men}

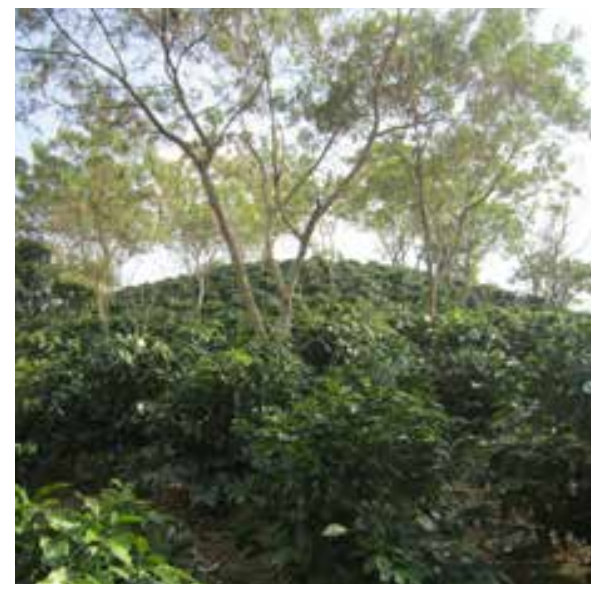

Coffee intercropped with shade trees (Leucaena leucocephala).

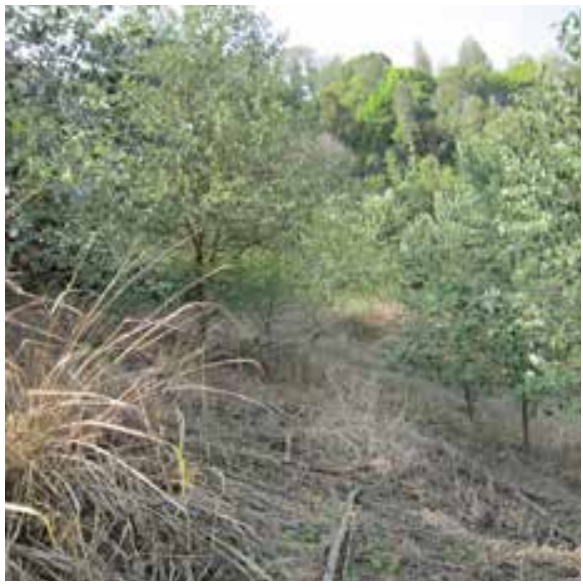

Son Tra field: Son Tra trees are planted with a tree distance of $6 m \times 6 m$.

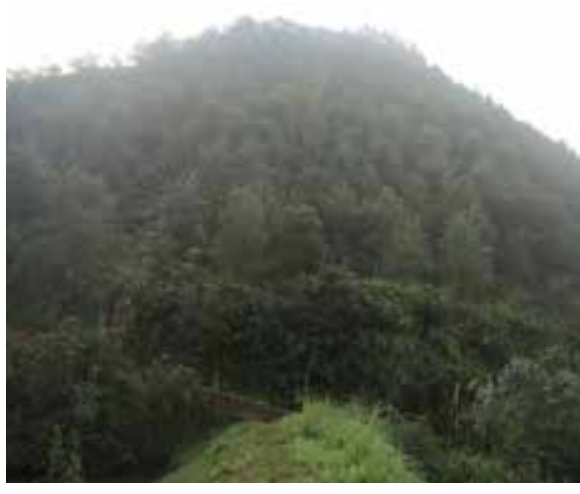

Wishing to have son tra fields with a lot of trees and fruits. 


\section{Older Hmong men}

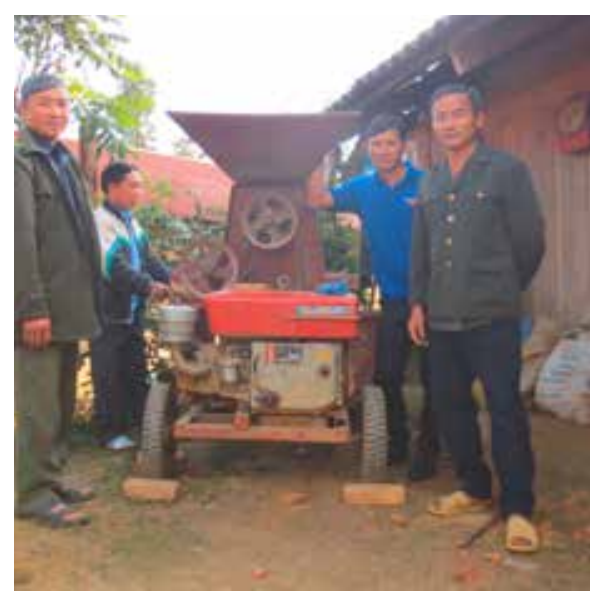

Milling machine could help farmers reduce labour time for Hmong farmers.

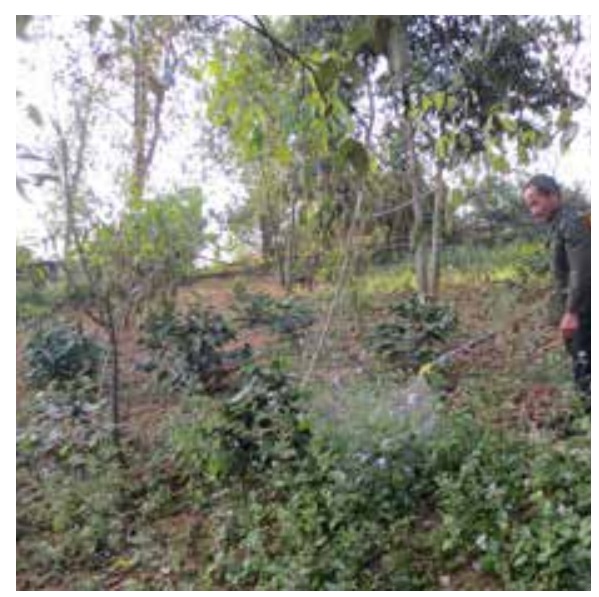

Using pesticide spraying, but it is highly toxic.

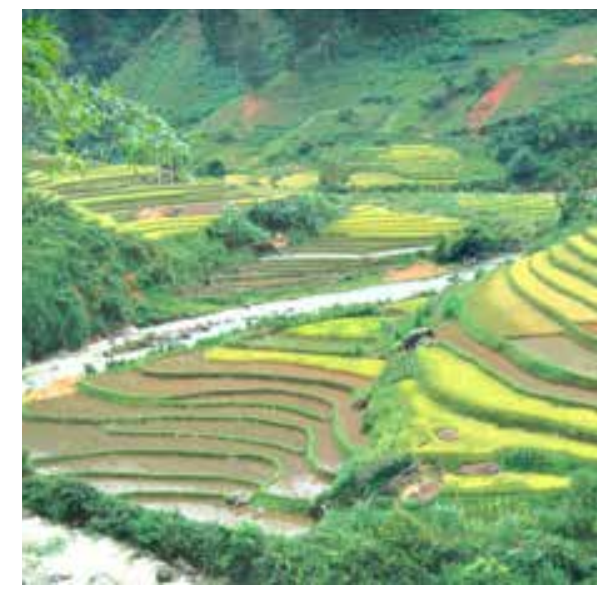

Terrace can prevent soil erosion.

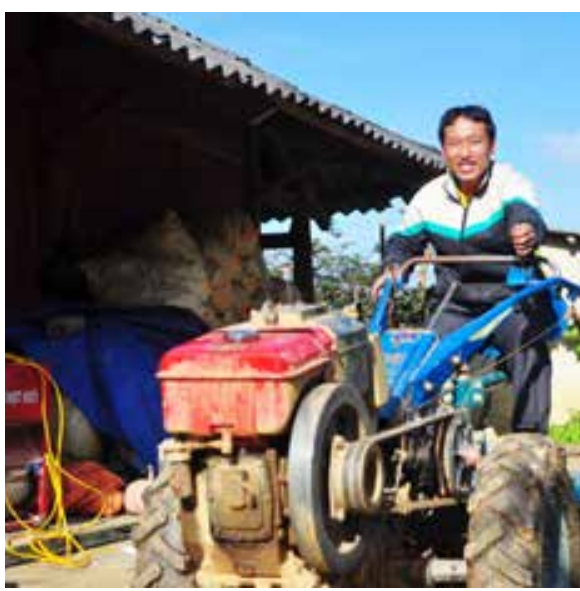

Agri-motor helps reduce time and labour for farmers.

\section{Younger Hmong women}

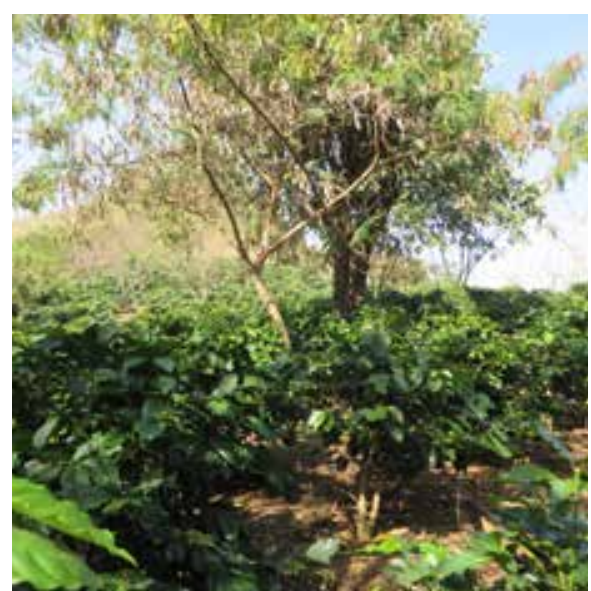

I want a coffee plant like this.

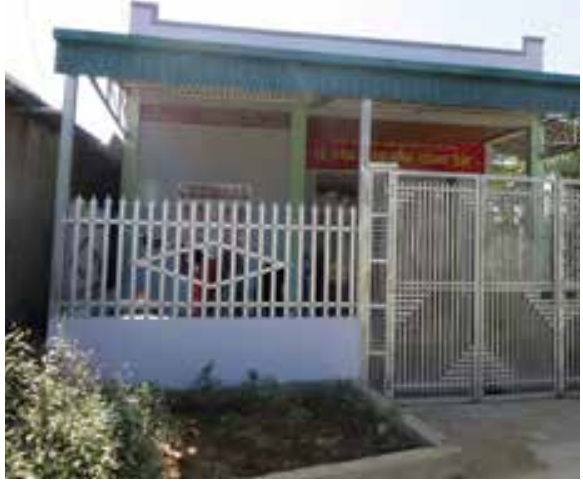

This is my dream house.

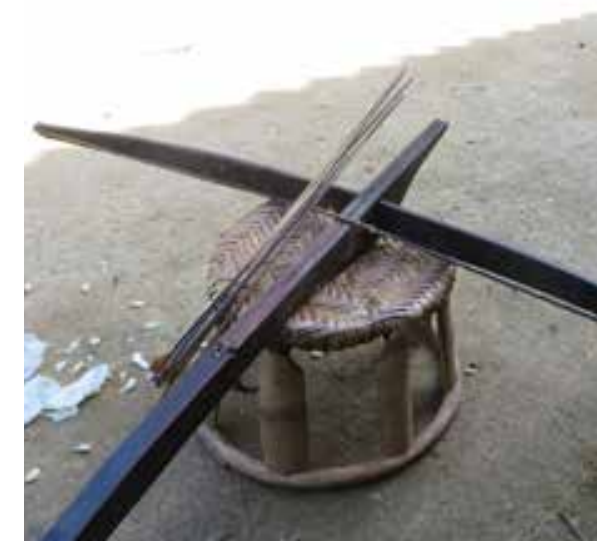

Archery is my favourite sport. I hope I could go for competitions at district and province level. 


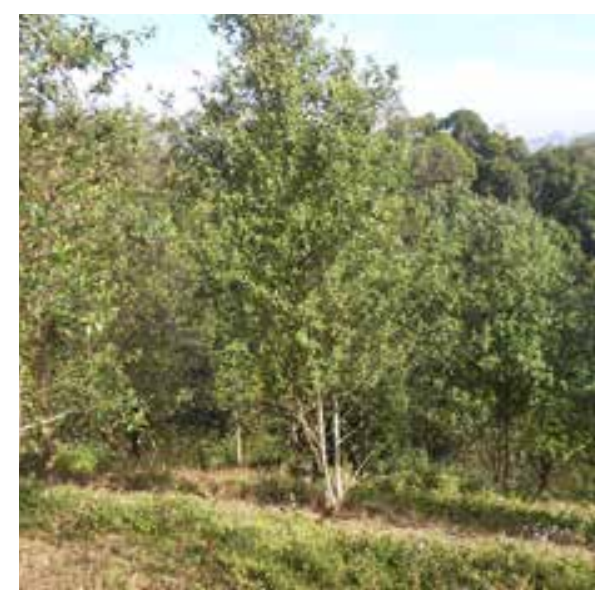

My dream is to have a good son tra field like this.

\section{Older Hmong women}

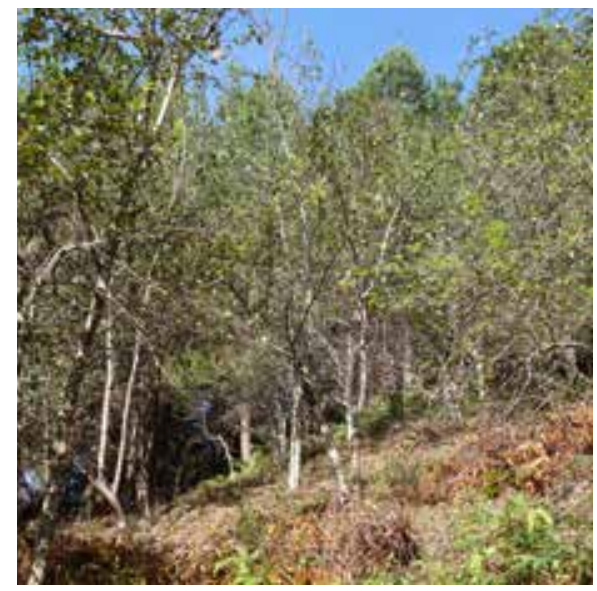

Good son tra field: not too steep, Paved road. trees grow big, leaves are green, trees bear lots of fruits.

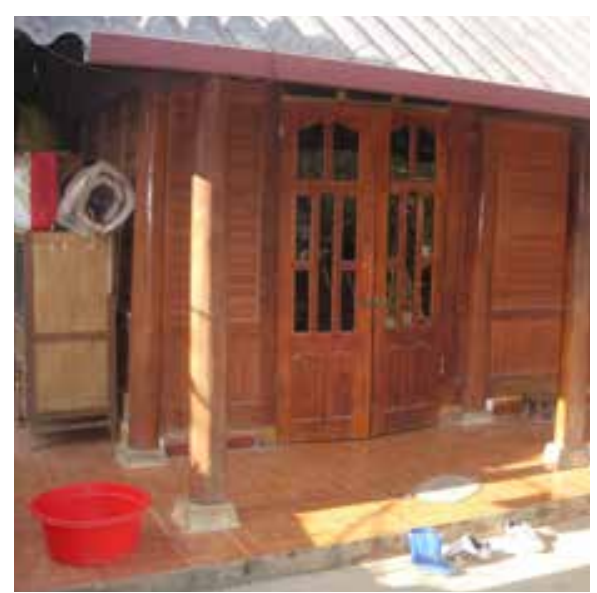

Nice house.

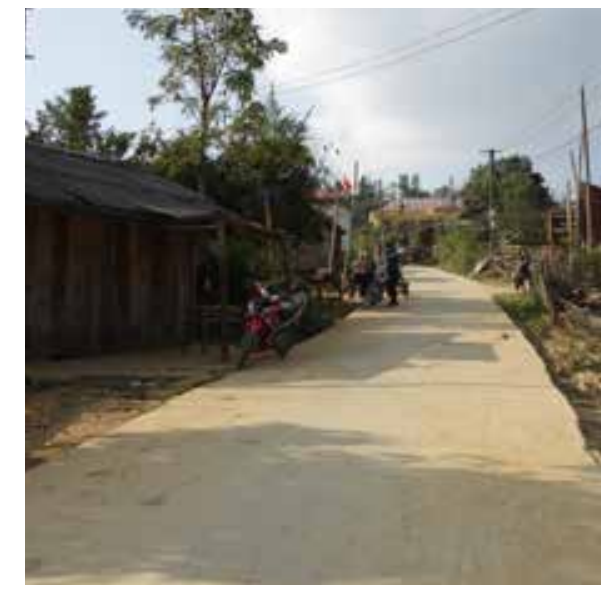




\section{THAI GROUP}

\section{Younger Thai men}
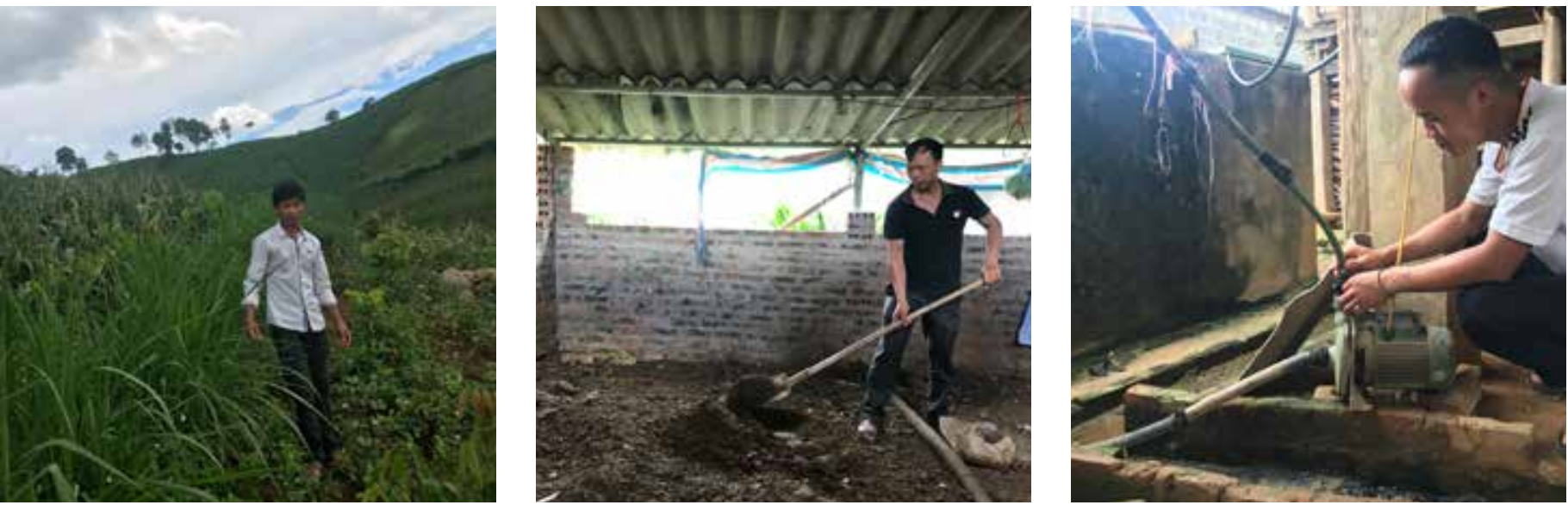

Planting grass to reduce soil loss. Making organic fertilizer.

Installing pumping water system.

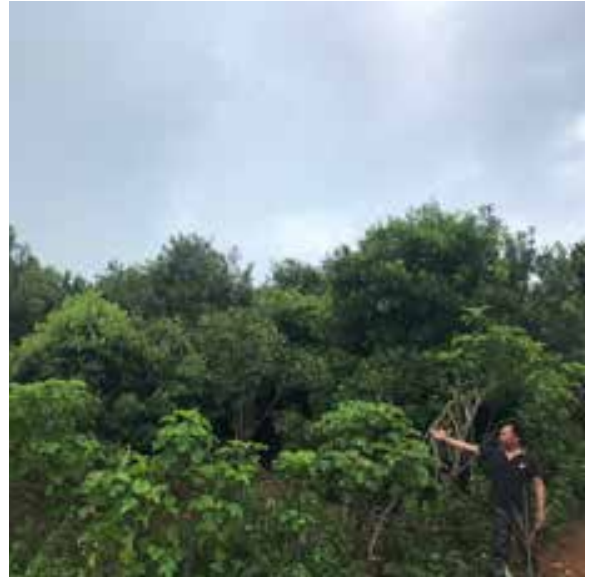

Agroforestry system (macadamia and longan).

\section{Older Thai men}

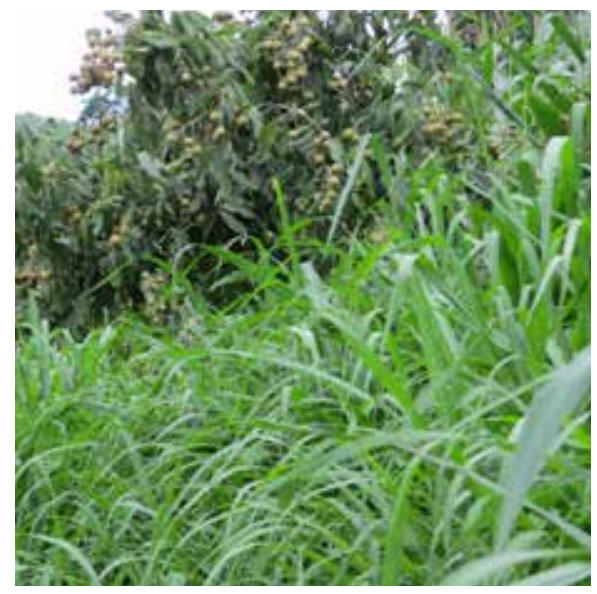

Planting grass to prevent soil erosion.

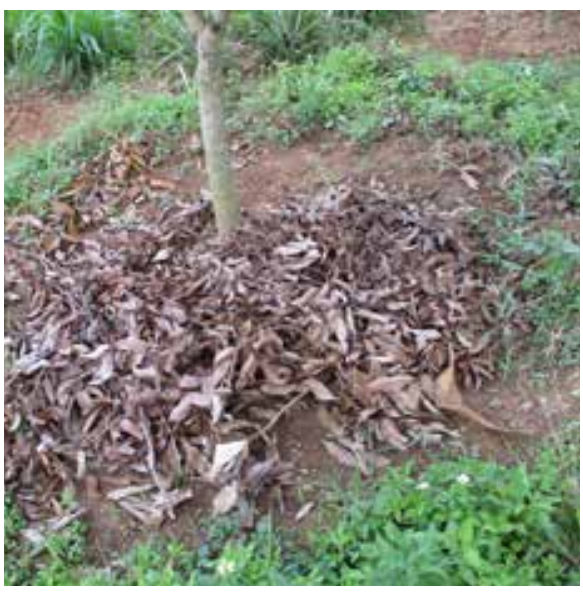

Leaving residue in the field after pruning.

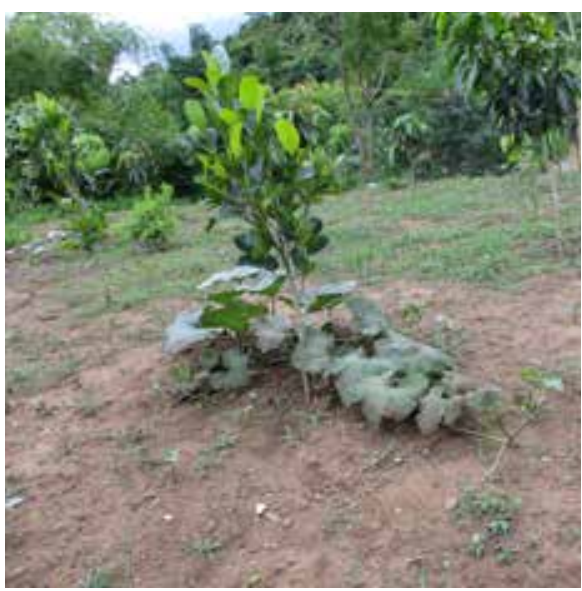

Intercropping pumpkin with fruit trees. 


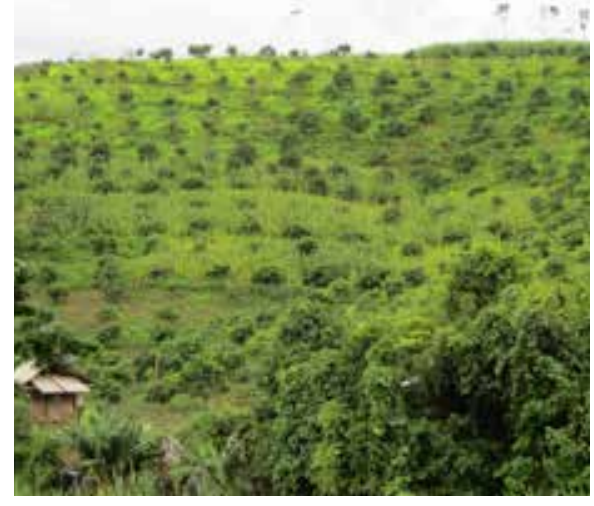

Agroforestry landscape with fruit trees.

\section{Younger Thai women}

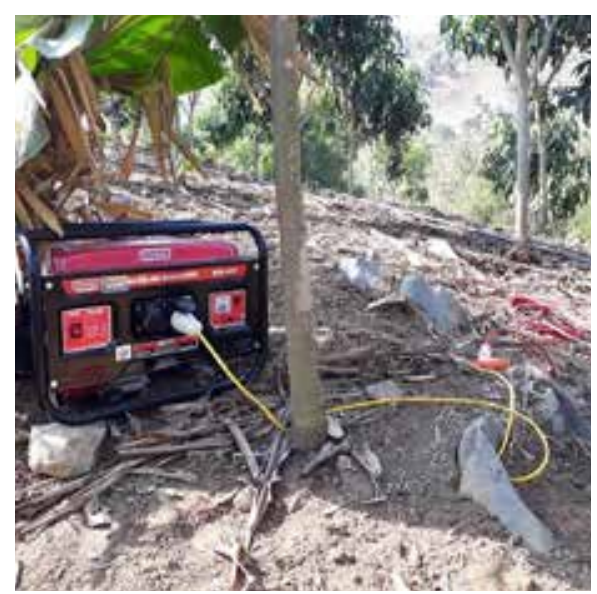

Water pumping machine for irrigation up the hill.

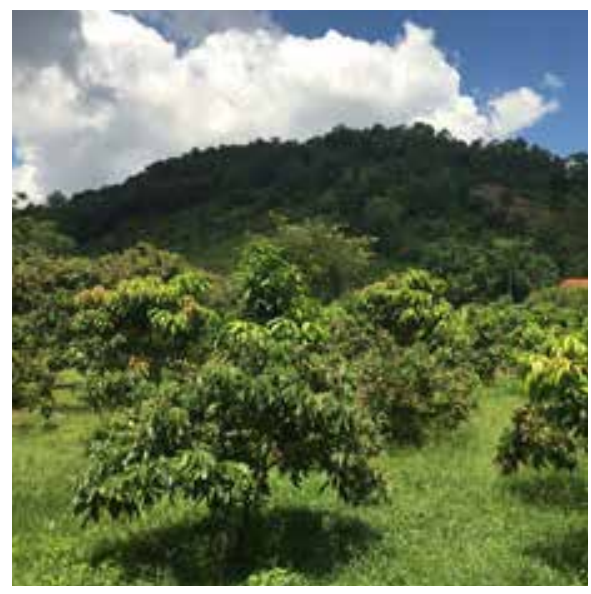

Not too steep and diverse species in the field.

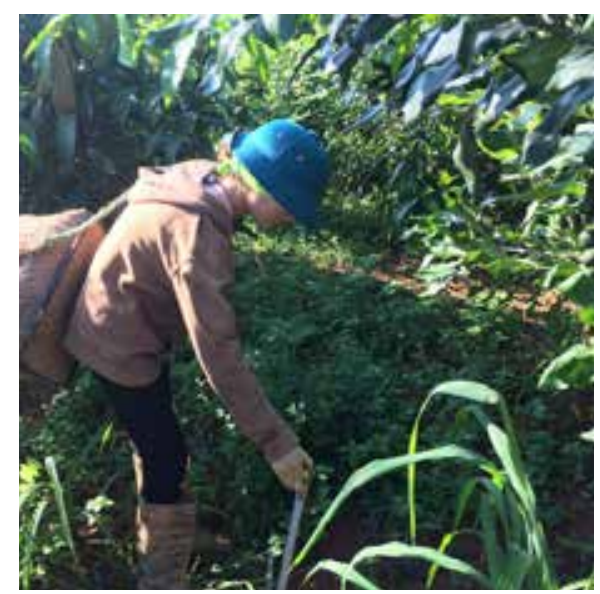

Planting elephant grass to reduce soil loss.

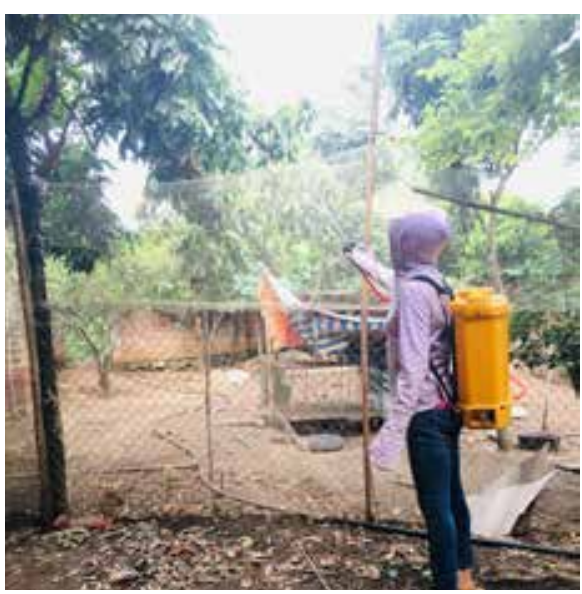

Spraying fuel mixed with water as pesticide. 


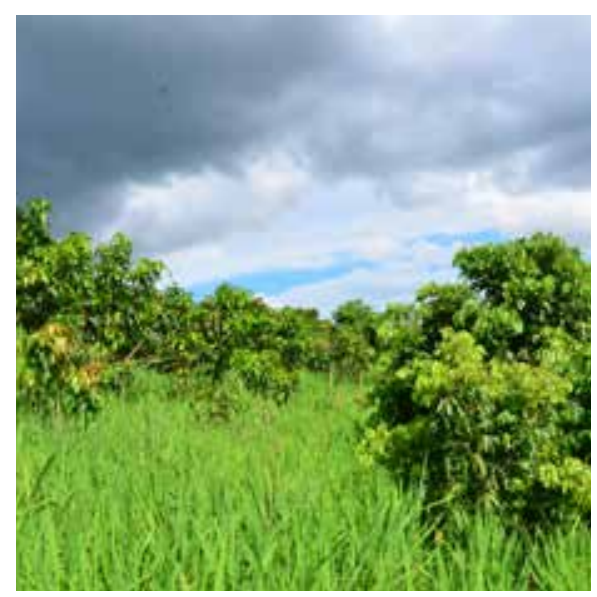

Converting maize to fruit trees.

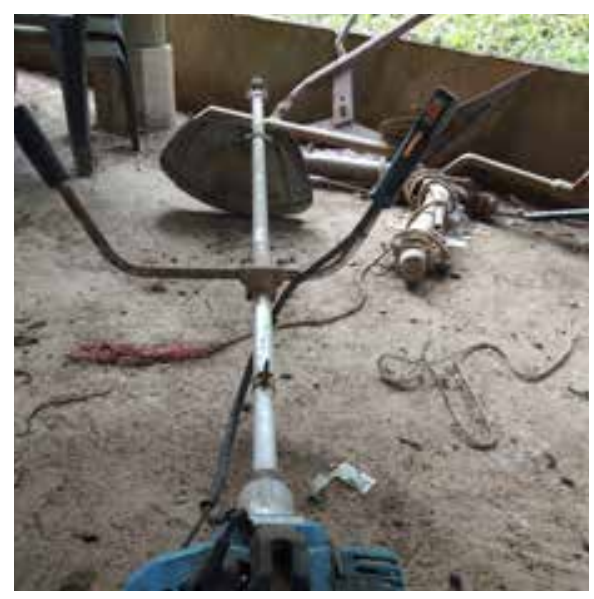

Weeding machine to save time.

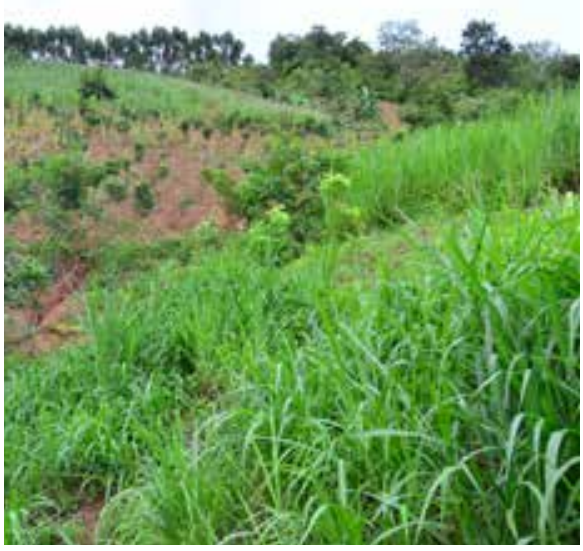

Planting guinea grass to prevent soil erosion.

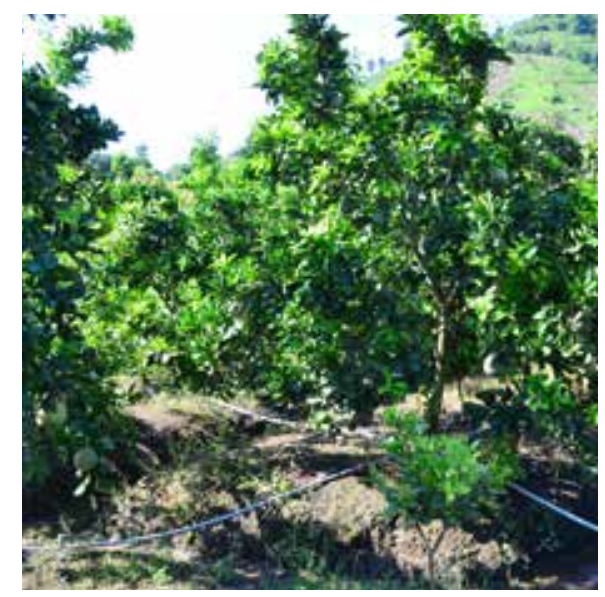

Pomelo garden with automatic irrigation system. 


\section{References}

Alkire S, Meinzen-Dick R, Peterman A, Quisumbing A, Seymour G, Vaz A. 2013. The Women's Empowerment in Agriculture Index. World Development 52:71-91.

Alvi M, Barooah P, Gupta S, Saini S. 2021. Women's access to agriculture extension amidst COVID-19: Insights from Gujarat, India and Dang, Nepal. Agricultural Systems 188(2021):103035.

Brandth B. 2002. Gender identity in European family farming: a literature review. Sociologia Ruralis 42(3):181-200.

CARE International. 2017. Social Analysis \& Action (SAA). Global implementation manual. Geneva, Switzerland: CARE International.

Catacutan D, Naz R. 2015. Gender roles, decision-making and challenges to agroforestry adoption in Northwest Vietnam. International Forestry Review 17(4):22-32.

Chikoko MG. 2002. A comparative analysis of household owned woodlots and fuelwood sufficiency between female and male headed households: a pilot study in rural Malawi, Africa. PhD dissertation. Corvallis OR, USA: Oregon State University.

Dang H. 2012. Vietnam: a widening poverty gap for ethnic minorities. SSRN Electronic Journal. DOI: $10.2139 /$ ssrn.2346307.

Diawuo F, Kosoe EA, Doke DA. 2019. Participation of women farmers in agroforestry practices in the Jaman South Municipality, Ghana. Ghana Journal of Development Studies 16(2):267-289.

Doss C, Meinzen-Dick R, Quisumbing A, Theis S. 2017. Women in agriculture: four myths. Global Food Security 16(2018):69-74.

[FAO] Food and Agriculture Organization of the United Nations. 2019. Country gender assessment: of agriculture and the rural sector in Viet Nam. Ha Noi, Viet Nam: Food and Agriculture Organization of the United Nations.

[FAO] Food and Agriculture Organization of the United Nations. 2015. Understanding women's participation in forestry in Vietnam. Bangkok, Thailand: Food and Agriculture Organization of the United Nations; RECOFTC.

Green Climate Fund. 2020. Gender assessment: FP125: strengthening the resilience of smallholder agriculture to climate change-induced water insecurity in the Central Highlands and SouthCentral Coast regions of Vietnam. Ha Noi, Viet Nam: United Nations Development Programme.

Kawarazuka N, Prain G. 2019. Gendered processes of agricultural innovation in the Northern uplands of Vietnam. International Journal of Gender and Entrepreneurship 11(3):210-226.

Kiptot E, Franzel S. 2012. Gender and agroforestry in Africa: a review of women's participation. Agroforestry Systems 84(1):35-58.

Lee GY. 2005. The shaping of traditions: agriculture and Hmong society. Hmong Studies Journal 6:1-33.

Malone P, Akbar SU, Bell M, Bohn AB. 2013. Report on the status of ICT for agricultural extension in Bangladesh: MEAS ICT Support Project. Agrilinks. http://www.agrilinks.org. 
Mamun-ur-Rashid M, Kamruzzaman M, Mustafa E. 2017. Women participation in agricultural extension services in Bangladesh: current status, prospects and challenges. Bangladesh Journal of Extension Education 29(1\&2):93-107.

Manfre C, Rubin D, Allen A, Summerfield G, Colverson K, Akeredolu M. 2013. Reducing the gender gap in agricultural extension and advisory services: how to find the best fit for men and women farmers. Urbana IL, USA: Modernizing Extension and Advisory Services. http://www.meas. illinois.edu.

Mbo'o-Tchouawou M, Colverson KE. 2014. Increasing access to agricultural extension and advisory services: how effective are new approaches in reaching women farmers in rural areas? ILRI Project Report. Nairobi, Kenya: International Livestock Research Institute.

Meinzen-Dick R, Quisumbing A, Behrman J, Biermayr-Jenzano P, Wilde V, Noordeloos M, Ragasa C, Beintema N. 2010. Engendering agricultural research: IFRI Discussion Paper 00973. Washington DC, USA: International Food Policy Research Institute.

Menon N, Rodgers Y, Nguyen H. 2014. Women's land rights and children's human capital in Vietnam. World Development 54:18-31.

Mudege NN, Mdege N, Abidin PE, Bhatasara S. 2017. The role of gender norms in access to agricultural training in Chikwawa and Phalombe, Malawi. Gender, Place and Culture 24(12):1689-1710.

Mudege NN, Chevo T, Nyekanyeka T, Kapalasa E, Demo P. 2015. Gender norms and access to extension services and training among potato farmers in Dedza and Ntcheu in Malawi. The Journal of Agricultural Education Extension 22(3):291-305.

Nellemann C, Verma R, Hislop L, eds. 2011. Women at the frontline of climate change: gender risks and hopes: a rapid response assessment. Nairobi, Kenya: United Nations Environment Programme; Arendal, Norway: GRID-Arendal.

Peterman A, Behrman J, Quisumbing AR. 2014. A review of empirical evidence on gender differences in nonland agricultural inputs, technology, and services in developing countries. In: Quisumbing AR, Meinzen-Dick R, Raney TL, Croppenstedt A, Behrman JA, Peterman A. Gender in agriculture: closing the knowledge gap. Dordrecht, Netherlands: Springer. pp 145-186.

Petesch P, Badstue L, Prain G. 2018. Gender norms, agency, and innovation in agriculture and natural resource management: The GENNOVATE methodology. El Batan, Mexico: Centro Internacional de Mejoramiento de Maíz y Trigo.

Qian N. 2008. Missing women and price of tea in China: the effect of sex-specific earnings on sex imbalance. Quarterly Journal of Economics 123(3):1251-85.

Raghunathan K, Kannan S, Quisumbing AR. 2018. Can women's self-help groups improve access to information, decision-making, and agricultural practices? The Indian case. Agricultural Economics 50(5):567-580.

Rose G. 1993. A politics of paradoxical space. Feminism and Geography: The Limits of Geographical Knowledge 137(60):184-202.

Sraboni E, Quisumbing AR, Ahmed AU. 2014. How empowered are Bangladeshi women in agricultural setting? Empirical evidence using a new index. Bangladesh Development Studies 138(3):1-25.

Sulaiman R, Reddy TSV. 2014. Assessment of extension and advisory methods and approached to reach rural women: examples from India. Urbana IL, USA: Modernizing Extension and Advisory Services. http://www.meas.illinois.edu.

Luke N, Munshi K. 2011. Women as agents of change: female income and mobility in India. Journal 
of Development Economics 94(1):1-17.

[UN Women] United Nations Entity for Gender Equality and the Empowerment of Women. 2017. Figures on ethnic minority women and men in Viet Nam 2015. Ha Noi, Viet Nam: United Nations Entity for Gender Equality and the Empowerment of Women.

Voegele J, Villarreal M, Cooke R. 2009. Gender in agriculture: sourcebook module 1. Washington DC USA: The World Bank.

World Agroforestry (ICRAF). 2017. Gender-responsive participatory tools: a guide for facilitators. Nairobi, Kenya: World Agroforestry (ICRAF).

World Bank. 2019. Vietnam: ethnic minority children are disproportionately undernourished. Washington DC USA: The World Bank. https://www.worldbank.org. 


\section{Recent titles in the working paper series}

\section{9}

292: Los árboles fuera del bosque en la NAMA forestal de Colombia. Elementos conceptuales para su contabilización. http://dx.doi.org/10.5716/WP19002.PDF

293: Gender and Adaptation: An Analysis of Poverty and Vulnerability in Yunnan, China. http:// dx.doi.org/10.5716/WP19004.PDF

294: Tree Cover on Agricultural Land in the Asia Pacific Region. http://dx.doi.org/10.5716/WP19005. PDF

295: What do we really know about the impacts of improved grain legumes and dryland cereals? A critical review of 18 impact studies.vhttp://dx.doi.org/10.5716/WP19006.PDF

296: Breeders' views on the production of new and orphan crops in Africa: a survey of constraints and opportunities. http://dx.doi.org/10.5716/WP19007.PDF

297: Biomass Resources in Rhino Camp and Imvepi Refugee Settlements and the Buffer Zone around these Settlements in West Nile, Uganda. http://dx.doi.org/10.5716/WP19031.PDF

298: Option for restocking woody biomass in refugee-hosting areas: Perspectives from communities in Rhino Camp and Imvepi Settlements, Uganda. http://dx.doi.org/10.5716/WP19032.PDF

299: Restoring ecosystems in refugee settlements using tree-based systems: The case of Rhino Camp and Imvepi Settlements in Uganda.

http://dx.doi.org/10.5716/WP19033.PDF

300: A theory-based evaluation of the Agroforestry Food Security Programme, Phase II in Malawi (AFSPII): Lessons for Scaling Up Complex Agronomic and Natural Resource Management Practices Developed and Tested in Research Settings.

http://dx.doi.org/10.5716/WP19036.PDF

301: Fuentes semilleras y especies agroforestales de los bosques secos tropicales del norte del Perú: estado actual y prioridades futuras. (Spanish)

http://dx.doi.org/10.5716/WP19057.PDF

302: Seed sources and agroforestry species of tropical dry forests of northern Peru: current status and future priorities. (English)

http://dx.doi.org/10.5716/WP19058.PDF

303: Turmeric Production under Shade Management and Fertilization in Degraded Landscapes of Sumba Timur.

http://dx.doi.org/10.5716/WP19066.PDF

2020

304: From Tree Planting to Tree Growing: Rethinking Ecosystem Restoration Through Trees. http:// dx.doi.org/10.5716/WP20001.PDF 
305: Agroforestry species of Peru: Reference list and contribution to prioritization for the conservation of agroforestry genetic resources.

http://dx.doi.org/10.5716/WP20013.PDF

306: An exploratory analysis of cost-benefit analysis of landscape restoration. http://dx.doi. org/10.5716/WP20014.PDF

307: Wood fuel value chains in Kenya: a 20-year synthesis. http://dx.doi.org/10.5716/WP20026.PDF

308: Especies agroforestales del Perú: Lista referencial y contribución a la priorización para la conservación de recursos genéticos agroforestales. Documento de Trabajo número 308. Centro Internacional de Investigación Agroforestal

http://dx.doi.org/10.5716/WP20041.PDF

309: Simulasi Dampak Perubahan Tutupan Lahan dan Curah Hujan di DAS Citarum Hulu dengan Model GenRiver: Kalibrasi model dan analisa sensitivitas.

Authors: Lisa Tanika, Betha Lusiana dan Adis Hendriatna

http://dx.doi.org/10.5716/WP20048.PDF

310: Simulating the effect of change in land cover and rainfall in Upper Citarum Watershed: calibration and sensitivity analysis of Genriver model

Authors: Lisa Tanika, Betha Lusiana dan Adis Hendriatna

http://dx.doi.org/10.5716/WP20049.PDF

311: Status of Perennial Tree Germplasm Resources in India and their Utilization in the Context of Global Genome Sequencing Efforts

http://dx.doi.org/10.5716/WP2020050.PDF

312: Kindt R, Dawson IK, Lilles $\varnothing$ J-PB, Muchugi A, Pedercini F, Roshetko JM, van Noordwijk M, Graudal L, Jamnadass $R$. The one hundred tree species prioritized for planting in the tropics and subtropics as indicated by database mining. World Agroforestry, Nairobi, Kenya. DOI http://dx.doi. org/10.5716/WP21001.PDF

313: Amaruzaman S, Isnurdiansyah B L. 2021. Land-use Land-cover Change and Farming systems in the upland of Pagar Alam City, Indonesia. DOI: http://dx.doi.org/10.5716/WP21007.PDF

314: Effect of COVID-19 on rural community enterprises: the case of community forest enterprises in Cameroon. DOI: http://dx.doi.org/10.5716/WP21007.PDF. 
World Agroforestry (ICRAF) is a centre of scientific and development excellence that harnesses the benefits of trees for people and the environment. Leveraging the world's largest repository of agroforestry science and information, we develop knowledge practices, from farmers' fields to the global sphere, to ensure food security and environmental sustainability.

ICRAF is the only institution that does globally significant agroforestry research in and for all of the developing tropics. Knowledge produced by ICRAF enables governments, development agencies and farmers to utilize the power of trees to make farming and livelihoods more environmentally, socially and economically sustainable at multiple scales.

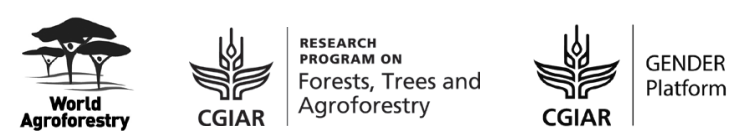

Country Program $\bullet$ Ha Noi $\bullet$ Viet Nam

HCMCC Tower $\bullet 13$ th Floor $\bullet$ Thuy Khue street $\bullet$ Tay Ho district

Telephone: +842437834645 • Fax: +842437834645

Email: icraf-vietnam@cgiar.org • www.worldagroforestry.org/country/Vietnam

United Nations Avenue, Gigiri • PO Box $30677 \bullet$ Nairobi, $00100 \bullet$ Kenya

Telephone: +254207224000 or via USA +1 6508336645

Fax: +254 207224001 or via USA +1 6508336646

Email: worldagroforestry@cgiar.org •www.worldagroforestry.org 